\title{
Imidazoles as Potential Anticancer Agents: An Update on Recent Studies
}

\author{
Pankaj Sharma ${ }^{1} \mathbb{D}$, Chris LaRosa ${ }^{1}$, Janet Antwi ${ }^{2}$, Rajgopal Govindarajan ${ }^{3}$ and Karl A. Werbovetz ${ }^{1, * \mathbb{D}}$ \\ 1 Division of Medicinal Chemistry and Pharmacognosy, College of Pharmacy, The Ohio State University, \\ Columbus, OH 43210, USA; sharma.1032@osu.edu (P.S.); larosa.18@osu.edu (C.L.) \\ 2 Division of Mathematics, Computer \& Natural Sciences Division, Ohio Dominican University, \\ Columbus, OH 43219, USA; antwij@ohiodominican.edu \\ 3 Division of Pharmaceutics and Pharmacology, College of Pharmacy, The Ohio State University, \\ Columbus, OH 43210, USA; govindarajan.21@osu.edu \\ * Correspondence: werbovetz.1@osu.edu
}

Citation: Sharma, P.; LaRosa, C.;

Antwi, J.; Govindarajan, R.;

Werbovetz, K.A. Imidazoles as Potential Anticancer Agents: An Update on Recent Studies. Molecules 2021, 26, 4213. https://doi.org/ $10.3390 /$ molecules 26144213

Academic Editor: Carlotta Granchi

Received: 26 May 2021

Accepted: 5 July 2021

Published: 11 July 2021

Publisher's Note: MDPI stays neutral with regard to jurisdictional claims in published maps and institutional affiliations.

Copyright: (c) 2021 by the authors. Licensee MDPI, Basel, Switzerland. This article is an open access article distributed under the terms and conditions of the Creative Commons Attribution (CC BY) license (https:// creativecommons.org/licenses/by/ $4.0 /)$.

\begin{abstract}
Nitrogen-containing heterocyclic rings are common structural components of marketed drugs. Among these heterocycles, imidazole/fused imidazole rings are present in a wide range of bioactive compounds. The unique properties of such structures, including high polarity and the ability to participate in hydrogen bonding and coordination chemistry, allow them to interact with a wide range of biomolecules, and imidazole-/fused imidazole-containing compounds are reported to have a broad spectrum of biological activities. This review summarizes recent reports of imidazole/fused imidazole derivatives as anticancer agents appearing in the peer-reviewed literature from 2018 through 2020. Such molecules have been shown to modulate various targets, including microtubules, tyrosine and serine-threonine kinases, histone deacetylases, p53-Murine Double Minute 2 (MDM2) protein, poly (ADP-ribose) polymerase (PARP), G-quadraplexes, and other targets. Imidazole-containing compounds that display anticancer activity by unknown/undefined mechanisms are also described, as well as key features of structure-activity relationships. This review is intended to provide an overview of recent advances in imidazole-based anticancer drug discovery and development, as well as inspire the design and synthesis of new anticancer molecules.
\end{abstract}

Keywords: imidazole; benzimidazole; purine; anticancer; antimicrotubule; kinase inhibitor

\section{Introduction}

According to the 2020 World Cancer Report, slightly over 18 million new cases of cancer and nearly 10 million cancer-related deaths occurred across the globe in 2018 [1]. Cancer is also the first or second leading cause of premature death in people of ages 30-69 in most countries worldwide. It is characterized by uncontrolled cell growth which may spread to other parts of the body (known as metastasis) and invade other tissues. Although prevention efforts are critical to limit cancer incidence, the treatment of cancer often involves pharmacologic intervention. Cytotoxic chemotherapeutic agents continue to play an important role in cancer pharmacotherapy, but discovery efforts have increasingly turned to targeted therapies (drugs interfering with processes unique to the proliferation and spread of cancer cells) and immunotherapy (boosting the immune system or changing how the immune system works) as effective and less toxic forms of pharmacotherapy for cancer $[2,3]$. While numerous anticancer drugs are available, many forms remain difficult to cure, resulting in the mortality rates mentioned above. The toxicity, rapid development of resistance, and limited efficacy associated with currently available anticancer agents highlight the urgency to discover new compounds that can overcome the limitations of existing drugs [4].

An analysis of U.S. FDA approved drugs revealed that $59 \%$ of these small-molecule agents include nitrogen-containing heterocycles [5]. Imidazole is among the top ten and 
fused imidazoles (benzimidazole and imidazopyrimidine (purine)) are among the top 25 most frequently appearing nitrogen heterocycles in such small molecule drugs [5]. These ring systems are key components of structural scaffolds occurring in modern medicinal chemistry, thus forming critical building blocks for new drug design. Compounds containing an imidazole ring display a wide range of pharmacological activities including anticancer [6], antibacterial [7], antiviral [8], antiepileptic [9], antitubercular [10], and antifungal activities [11]. A range of anticancer drugs, such as dacarbazine (1), bendamustine hydrochloride (2), fludarabine phosphate (3), nilotinib (4), and ponatinib (5), contain imidazole and fused imidazole as structural components (see Figure 1). Many biological targets have been investigated and identified for imidazole and fused imidazole derivatives through which they are thought to exhibit their anticancer activities. These proposed targets include tubulin/microtubules, a range of kinases, histone deacetylases and other proteins that regulate gene expression, and additional targets as detailed in this review article.<smiles>CN(C)/N=N/c1[nH]cnc1C(N)=O</smiles>

dacarbazine (1)<smiles>Cn1c(CCCC(=O)O)nc2cc(N(CCCl)CCCl)ccc21</smiles>

bendamustine hydrochloride (2)<smiles>Nc1nc(F)nc2c1ncn2C1OC(COP(=O)(O)O)[C@@H](O)C1O</smiles>

fludarabine phosphate (3)<smiles>Cc1cn(-c2cc(NC(=O)c3ccc(C)c(Nc4nccc(-c5cccnc5)n4)c3)cc(C(F)(F)F)c2)cn1</smiles>

nilotinib (4)<smiles>Cc1ccc(C(=O)Nc2ccc(CN3CCN(C)CC3)c(C(F)(F)F)c2)cc1C#Cc1cnc2cccnn12</smiles>

ponatinib (5)

Figure 1. Selected anticancer drugs containing imidazole and fused imidazole moieties.

Imidazole, a five-membered heterocycle, is highly polar (experimental $\log \mathrm{P}$ close to zero) [12] due to the presence of two nitrogen atoms. This ring system can serve as an acid or a base; imidazole can act as a hydrogen bond donor if it is not substituted at $\mathrm{N} 1$ and is also capable of coordinating metals $[13,14]$. In addition to hydrogen bonding and coordination, imidazole can participate in van der Waals interactions, $\pi-\pi$ stacking, cation $-\pi$ interactions, and other interactions [15]. The versatility of imidazole in terms of its molecular interactive properties is reflected by its presence in the amino acid histidine and in the purine bases, thus making imidazole ubiquitous in biochemistry. The first synthesis of imidazole, in which glyoxal, ammonia, and formaldehyde reacted to prepare the ring in low yield, was reported by Debus in 1858 [16]. The Radiszewski synthesis [17] is an extension of the Debus synthesis in which 1,2-dicarbonyl compounds, aldehydes, and amines react to form substituted imidazoles, a method that is still employed for the synthesis of various substituted imidazoles. The Wallach synthesis [18] and the Marckwald synthesis [19] are other named reactions employed for the synthesis of imidazoles, but numerous approaches have been reported for the preparation of this ring system. Reviews by Sharma et al. [20], Vessaly et al. [21], Hossain and Nanda [22], Soni et al. [23], and Shabalin and Camp [24] have described various methods used for the synthesis of imidazoles. The review by Alaqueel et al. reported that benzimidazole preparation is generally through the reaction of $o$-phenylenediamine with different benzaldehydes [25], 
while the purine nucleus is often prepared by the Traube synthesis [26] or its modern variations [27]. Purine ring systems may also be preformed and modified at electrophilic sites in the process of analog preparation. Imidazole-containing heterocycles are also known as privileged scaffolds due to their wide range of biological activities, prompting the publication of comprehensive review articles detailing such activities $[15,28,29]$. In 2017, Ali et al. summarized the potential of imidazoles as anticancer agents [6]. Since this review by Ali et al., numerous studies detailing the anticancer potential of such compounds have appeared. Therefore, the present review addresses recent developments concerning imidazole-based compounds displaying anticancer activity published from 2018-2020. We apologize for any unintentional omission of relevant published research articles which we have missed in preparing this manuscript. Nevertheless, this review summarizes approximately 120 original studies. The brief accounts of these publications included below recap the activity of imidazole-containing compounds against different cancer cell lines, offer a synopsis of structure-activity relationships in many cases, and provide highlights concerning in vivo efficacy. A strong focus has also been placed on mechanism of action studies. To this end, the candidate molecules described in this review are grouped according to their proposed molecular target, when possible, with an additional section containing molecules with unknown/uncharacterized targets. Thus, another goal of this review is to provide a representative sampling of the molecular targets that are being explored in current anticancer drug design. We hope that this review of the recent literature on imidazole- and fused imidazole-based compounds as anticancer candidates will be useful and motivating to researchers worldwide to aid the design and synthesis of compounds with improved potency along with high selectivity for different types of cancers.

\section{Imidazoles as Tubulin Polymerization Inhibitors}

Microtubules are the cylindrical components of the cytoskeleton (composed of $\alpha$ - and $\beta$-tubulin heterodimers) which are critical players in various cellular functions including the maintenance of cell shape, cell signaling, vesicular transport, and cell division. Because they are the primary component of the mitotic spindle, microtubules play an important role in the proliferation of cancer cells, thus making microtubules one of the most attractive targets for anticancer drugs (reviewed in reference [30]). Microtubule targeting agents can disrupt the formation of mitotic spindles at the metaphase/anaphase transition, altering tubulin assembly kinetics and causing cell-cycle arrest and apoptotic cell death. Although tubulin targeting compounds, such as taxanes [31], vinca alkaloids [32], and some newer agents, such as ixabepilone [33], are used for the treatment of cancer, multidrug resistance and poor bioavailability associated with these drugs pose challenges, as well as provide motivation, for researchers to identify new microtubule-targeted agents with high efficacy, an acceptable side effect profile, and good bioavailability.

1-Substituted-2-aryl imidazoles were synthesized by $\mathrm{Li}$ et al. as potential tubulintargeted anticancer agents [34]. The target compounds were tested on MDA-MB-468, MDAMB-231, T47D, HCT-15, HT29, and HeLa cancer cell lines along with a normal human umbilical vein endothelial cell line (HUVEC). Many of the compounds possessing an aromatic ring on the imidazole nitrogen atom displayed potent antiproliferative activities with $\mathrm{IC}_{50}$ values in the 80-1000 nM range. Among these, compound 6 (see Figure 2 for structures of compounds 6-19) showed the highest potency, with $\mathrm{IC}_{50}$ values from 80-200 nM against HCT-15, HT29, HeLa, and MDA-MB-468 cells, while compound 7 exhibited good potency against HeLa and HCT-15 cells ( $\mathrm{IC}_{50}$ values of 100 and $200 \mathrm{nM}$, respectively). In terms of the SAR, the placement of an aliphatic group on the imidazole nitrogen and the replacement of imidazole with an amide or ester group led to a loss of activity. Compound $\mathbf{6}$ was a better inhibitor of porcine brain tubulin polymerization $\left(\mathrm{IC}_{50}=0.4 \mu \mathrm{M}\right)$ than either colchicine $\left(\mathrm{IC}_{50}=7.5 \mu \mathrm{M}\right)$ or combretastatin $\mathrm{A}-4\left(\mathrm{IC}_{50}=1.1 \mu \mathrm{M}\right)$. At its $\mathrm{IC}_{50}$ concentration, compound 6 caused arrest of MDA-MB- 468 cells in the $\mathrm{G}_{2} / \mathrm{M}$ phase of the cell cycle. In an MDA-MB-468 breast cancer xenograft model performed in 
nude mice, i.p. administration of compound 6 (60 mg/ $\mathrm{kg}$ every other day for 21 days) suppressed tumor growth by $77 \%$ compared to control, without causing obvious weight loss in the animals.<smiles>[R]c1cc(-n2ccnc2-c2cc(OC)c(OC)c(OC)c2)ccc1OC</smiles>

6: $\mathrm{R}=\mathrm{NH}_{2}$

7: $\mathrm{R}=\mathrm{OH}$<smiles>COc1cc(C(=O)c2c[nH]c(-c3c[nH]c4cccc(C)c34)n2)cc(OC)c1OC</smiles><smiles></smiles>

14: $\mathrm{R}^{1}=\mathrm{R}^{2}=\mathrm{R}^{3}=\mathrm{OMe}$

15: $\mathrm{R}^{1}=\mathrm{R}^{3}=\mathrm{H}, \mathrm{R}^{2}=\mathrm{Cl}$<smiles>COc1cc(C(=O)c2c[nH]c(-c3c[nH]c4ccccc34)n2)cc(OC)c1OC</smiles>

VERU-111 (8)<smiles>[R]c1nc(C(=O)c2cc(OC)c(OC)c(OC)c2)c[nH]1</smiles>

11: $R=4$-indolyl

12: $R=6$-indolyl<smiles>COc1cc(C(=O)c2c[nH]c(-c3c[nH]c4ccccc34)n2)cc2c1OC=CO2</smiles><smiles>COc1cc(C(=O)c2[nH]c(-c3ccc(C)cc3)nc2C)cc(OC)c1OC</smiles>

BZML (13)<smiles>[R]c1ccc(-c2nc3sc(C4CC4)nn3c2/C=C2\C(=O)Nc3cc([R])c([R])cc32)cc1</smiles>

16: $R^{1}=R^{2}=H, R^{3}=O M e$

17: $\mathrm{R}^{1}=\mathrm{OMe}, \mathrm{R}^{2}=\mathrm{H}, \mathrm{R}^{3}=\mathrm{Cl}$

18: $\mathrm{R}^{1}=\mathrm{R}^{3}=\mathrm{Cl}, \mathrm{R}^{2}=\mathrm{H}$

19: $R^{1}=H, R^{2}=C l, R^{3}=M e$

Figure 2. Imidazole-containing tubulin assembly inhibitors reported in the literature (compounds 6-19).

Wang et al. designed novel anticancer compounds based on the clinical drug candidate VERU-111 (8) where structural modification of the 3,4,5-trimethoxyphenyl group in this compound led to improved anticancer activity [35]. The authors presented an elegant synthetic approach where 3-methoxybenzo[4,5]-dioxene (a ring system found in the most potent compound) was synthesized using a second-generation Grubbs catalyst via ring closing metathesis. The antiproliferative effects of these compounds were evaluated on A375, M14, and RPMI7951 human melanoma cell lines. Compound 9 (containing a 3-methoxybenzo[4,5]-dioxene ring system) was the most active, with $\mathrm{IC}_{50}$ values of $1.1 \mathrm{nM}, 1.2 \mathrm{nM}$ and $3.3 \mathrm{nM}$ on A375, M14, and RPMI7951 cell lines, respectively. When the trimethoxyphenyl group present in compound 8 was replaced with 
4-methoxybenzo[ $d][1,3]$ dioxole, 5-methoxy-2,3-dihydrobenzo[b][1,4]dioxene, or 6-methoxy3,4 -dihydro- $2 H$-benzo[b][1,4]dioxepine, the activity was greatest with the dioxole ringcontaining compound and decreased with increasing ring size. Incubation of compound 9 with bovine brain tubulin at a concentration of $10 \mu \mathrm{M}$ resulted in nearly complete inhibition of tubulin assembly. The X-ray crystal structure of compound 9 bound to the tubulin/stathmin-like domain of RB-3/tubulin tyrosine ligase complex confirmed that 9 binds to the colchicine site on $\beta$-tubulin. When given at a dose of $30 \mathrm{mg} / \mathrm{kg}$ every other day for 15 days by i.p. injection, compound 9 inhibited tumor growth by $73.9 \%$ in an A375 murine melanoma xenograft model without significant weight loss.

Additional work regarding 8 (also known as ABI-231) conducted by Wang et al. reported structure-activity relationship (SAR) studies around the 3-indole moiety of this molecule [36]. Target compounds were screened against the A375, WM164, and M14 human melanoma cell lines. Among these compounds, 10-12 displayed the greatest potency, with $\mathrm{IC}_{50}$ values ranging from 1.6-8.0 nM against the cancer cell lines tested. In terms of the SAR for 3-indolyl compounds, derivatives bearing bulky groups at the other positions on the indole ring system displayed reduced activity, while substitution with a methyl group at the 4-position of indole (compound 10) resulted in a marked increase in antiproliferative activity. When the point of attachment to the indole ring system was changed, compounds where trimethoxybenzoyl imidazole was placed at the 4-, 5-, or 6position of indole displayed superior antiproliferative activity compared to the compound harboring this substitution at the C7 position of indole. Compounds 10-12 were tested against the NCI 60 cell line panel and displayed low nanomolar $\mathrm{IC}_{50}$ values against most of these cell lines. At a concentration of $10 \mu \mathrm{M}$, compounds $\mathbf{1 0}$ and $\mathbf{1 1}$ completely inhibited the polymerization of purified bovine brain tubulin in vitro. Further, X-ray crystallographic studies verified that the lead compound $\mathbf{8}$, as well as compounds $\mathbf{1 0}$ and $\mathbf{1 1}$, bind at the colchicine site on tubulin. Intraperitoneal injection of compound $11(30 \mathrm{mg} / \mathrm{kg} /$ day on alternate days for 20 days) resulted in 90.6\% tumor growth inhibition in an A375 melanoma xenograft model in nude mice. In a lung metastasis model conducted in C57BL mice, animals treated with $30 \mathrm{mg} / \mathrm{kg}$ compound $\mathbf{1 1}$ for two weeks (five days per week) by intraperitoneal injection showed an $80.9 \%$ decrease in metastasis. Moreover, in a taxaneresistant PC-3 (PC-3/TxR) mouse model, administration of compound 11 (30 mg/kg) resulted in an $83.8 \%$ reduction in tumor growth and $62.8 \%$ decrease in the average tumor weight compared to controls.

Bai et al. reported on 5-(3,4,5-trimethoxybenzoyl)-4-methyl-2-( $p$-tolyl) imidazole (BZML, 13), a compound with potent activity against colorectal cancer cell lines that inhibits tubulin polymerization and causes DNA damage [37]. Compound $\mathbf{1 3}$ displayed potent $\mathrm{IC}_{50}$ values of 27.42, 23.12, and $33.14 \mathrm{nM}$ against SW480, HCT116, and Caco-2 cells, respectively, while the Caco-2 cell line was insensitive to both paclitaxel and doxorubicin $\left(\mathrm{IC}_{50}\right.$ values > $1800 \mathrm{nM}$ ). When tested at a concentration of $60 \mathrm{nM}$, compound 13 disrupted microtubules in these cell lines as assessed by immunofluorescence microscopy and increased the number of $\gamma$-H2AX foci in the cell lines mentioned above, indicating the induction of DNA damage. Moreover, this compound decreased P-glycoprotein (P-gp) expression and enhanced the activity of both doxorubicin and paclitaxel in the Caco-2 cell line at a concentration of $60 \mathrm{nM}$.

A series of new imidazopyridine-triazole conjugates were reported as potential tubulin polymerization inhibitors and were screened against A549, DU-145, HCT116, and MDA-MB 231 cancer cell lines [38]. Compounds 14 and 15 displayed IC $_{50}$ values of 0.51 and $0.63 \mu \mathrm{M}$ against the A549 cell line, respectively, and exhibited the greatest potency against the four cancer cell lines overall. At a concentration of $3 \mu \mathrm{M}$, compounds 14 and 15 inhibited tubulin polymerization in a fluorescence-based assay by $59 \%$ and $56 \%$, respectively, while the standard compound nocodazole displayed $55 \%$ inhibition. At $1 \mu \mathrm{M}$ concentrations, compounds 14 and 15 also caused a dramatic increase in the percentage of A549 cells in the $\mathrm{G}_{2} / \mathrm{M}$ phase. Molecules bearing an unsubstituted phenyl ring at the $\mathrm{C} 2$ position of the imidazopyridine system generally displayed the greatest potency. 
Narasimha Rao et al. synthesized a library of imidazothiadiazole-oxindole conjugates and evaluated their antimicrotubule activity, as well as their antiproliferative activity, against HeLa, MCF-7, and MIAPaCa-2 cancer cell lines and HEK-293 human embryonic kidney cells [39]. Compounds 16-19 displayed the greatest activity overall, exhibiting submicromolar or low micromolar $\mathrm{GI}_{50}$ values against all three cell lines. When compound 18 was screened against the NCI 60 cancer cell line panel, $\mathrm{GI}_{50}$ values below $5.0 \mu \mathrm{M}$ were observed against most of these cell lines, with the exception of leukemia and colon cancer cells. Compounds 16, 17, and 18 were inhibitors of bovine brain tubulin polymerization, displaying $\mathrm{IC}_{50}$ values of 5.6, 2.8, and $4.6 \mu \mathrm{M}$, respectively. Accumulation of HeLa cells in the $\mathrm{G}_{2} / \mathrm{M}$ phase was observed upon incubation with $5 \mu \mathrm{M}$ concentrations of compounds 16-18, while these compounds activated caspase- 3 in HeLa cells at $2 \mu \mathrm{M}$ concentrations. While the SAR was complex, inclusion of a nitro group either on the oxindole system or on the phenyl ring generally decreased the anticancer activity.

Baig et al. synthesized imidazothiazole-benzimidazole derivatives as potential tubulin polymerization inhibitors and tested their cytotoxicity against HeLa, A549, MCF-7, and DU145 cancer cell lines [40]. Compound 20 (see Figure 3 for structures of compounds 20-32) exhibited an $\mathrm{IC}_{50}$ value of $1.09 \mu \mathrm{M}$ against the A549 cancer cell line. Analogs bearing a 4-methoxy substitution on the phenyl ring at C6 of the imidazothiazole ring system generally displayed high activity against the A549 cell line, although the substitutions on the benzimidazole ring system at $\mathrm{C} 5$ also influenced activity. Compound 20 inhibited porcine tubulin polymerization in a fluorescence-based assay with an $\mathrm{IC}_{50}$ value of $1.68 \mu \mathrm{M}$, while the $\mathrm{IC}_{50}$ value for the standard compound nocodazole was $1.99 \mu \mathrm{M}$ in this assay. At a concentration of $2 \mu \mathrm{M}$, compound 20 caused the accumulation of $A 549$ cells in the $\mathrm{G}_{2} / \mathrm{M}$ phase of the cell cycle.

Donthiboina et al. synthesized benzimidazole-cinnamide derivatives as potential tubulin polymerization inhibitors and evaluated their activity against A549, MDA-MB-231, B16F10, BT474, and 4T1 cell lines [41]. Among the synthesized compounds, 21 displayed $\mathrm{IC}_{50}$ values in the range between 0.29 to $1.48 \mu \mathrm{M}$ against the cancer cell lines tested, exhibiting the greatest potency against A549 cells. Compound 21 also displayed an $\mathrm{IC}_{50}$ value of $1.58 \mu \mathrm{M}$ against a normal rat kidney epithelial cell line (NRK-52E cells). This compound inhibited porcine tubulin polymerization with an $\mathrm{IC}_{50}$ value of $4.64 \mu \mathrm{M}$, while incubation of A549 cells with $0.5 \mu \mathrm{M}$ concentrations of this compound caused an increase in the percentage of cells in the $\mathrm{G}_{2} / \mathrm{M}$ phase of the cell cycle. In general, compounds possessing electron donating substituents on the phenyl portion of the benzimidazole group were more active than compounds bearing electron withdrawing substituents.

Wang et al. synthesized a series of benzimidazole sulfonamides containing a substituted pyrazole ring at the $\mathrm{C} 2$ position [42]. These derivatives displayed $\mathrm{IC}_{50}$ values in the range between 0.15-7.26 $\mu \mathrm{M}$ against A549, HeLa, HepG2, and MCF-7 cancer cell lines. Compound 22 was the most potent derivative, displaying $\mathrm{IC}_{50}$ values of $0.15,0.21,0.33$, and $0.17 \mu \mathrm{M}$ against A549, HeLa, HepG2, and MCF-7 cells, respectively. This compound also showed low toxicity to murine primary hepatocytes and 293T cells $\left(\mathrm{CC}_{50}\right.$ values of 132 and $223 \mu \mathrm{M}$, respectively). In terms of the SAR for these derivatives against the cancer cell lines, placement of the benzene sulfonyl group on the benzimidazole nitrogen enhanced activity and the inclusion of 2,5-dimethyl, 4-methyl and 4-methoxy groups on the phenylsulfonyl ring increased potency. Compound 22 displayed an $\mathrm{IC}_{50}$ value of $1.52 \mu \mathrm{M}$ against porcine brain tubulin polymerization, while colchicine and combretastatin A4 displayed $\mathrm{IC}_{50}$ values of $2.26 \mu \mathrm{M}$ and $1.61 \mu \mathrm{M}$ in the same assay, respectively. At a concentration of $5 \mu \mathrm{M}$, compound 22 inhibited the binding of $\left[{ }^{3} \mathrm{H}\right]$ colchicine $(5 \mu \mathrm{M})$ to tubulin by $91 \%$. Incubation with this compound at a concentration of $0.5 \mu \mathrm{M}$ resulted in an increase in the percentage of $A 549$ cells in the $\mathrm{G}_{2} / \mathrm{M}$ phase. 


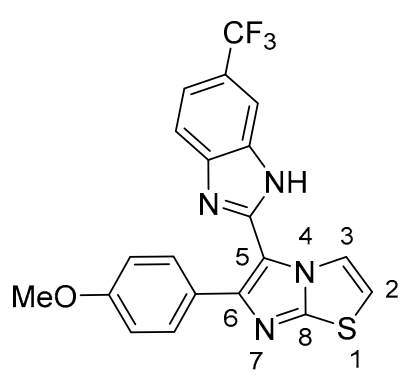

20

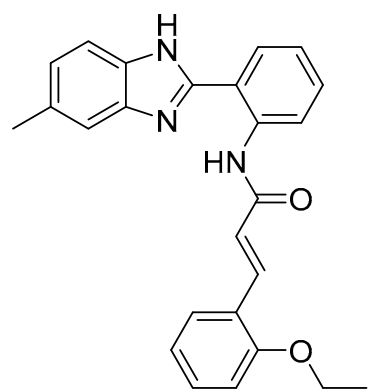

21<smiles>Cc1ccc(C)c(S(=O)(=O)n2c(-c3cn(-c4ccccc4)nc3-c3ccc(C(F)(F)F)cc3)nc3ccccc32)c1</smiles>

22<smiles></smiles>

24: $R=$ isopropyl<smiles>[R]n1cnc2c(NCc3c(CC)cc(CC)[nH]c3=O)nc(Cl)nc21</smiles>

25: $R=$ cyclopentyl<smiles>Cc1ncc([N+](=O)[O-])n1CCOC(=O)NC(Nc1ncccn1)C(Cl)(Cl)Cl</smiles>

$\operatorname{apcin}(26)$<smiles>[R]CCOC(=O)NC(C)n1cnc2c(N)nc(F)nc21</smiles>

27: $\mathrm{R}=\mathrm{H}$

28: $R=$ morpholino<smiles>Cc1ncc([N+](=O)[O-])n1CCOC(=O)NC(Nc1c(Cl)nc(N)nc1Cl)C(Cl)(Cl)Cl</smiles>

29<smiles>CCCCCCCCCCCCCCCC(C)(C)C</smiles>

Plinabulin (30)

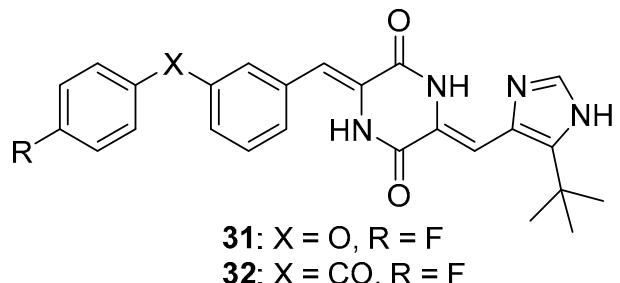

Figure 3. Additional imidazole-containing tubulin assembly inhibitors reported in the literature (compounds 20-32).

Zhang et al. synthesized aminomethyl dimethylpyridinones as potential anticancer agents against HepG2, HCT116, and A549 cancer cell lines and also evaluated their tubulin polymerization inhibitory activity [43]. Most of these compounds exhibited antiproliferative activity with $\mathrm{IC}_{50}$ values of $<10 \mu \mathrm{M}$ against these cell lines. Among these compounds, SKLB0533 (23) was the most potent, displaying $\mathrm{IC}_{50}$ values of $0.08,0.06$, and $0.10 \mu \mathrm{M}$ against HepG2, HCT116, and A549 cells compared to the standard compound myoseverin ( $\mathrm{IC}_{50}$ values of $3.06,7.82$, and $>10 \mu \mathrm{M}$, respectively). In general, substitution with 2-propyl, 3-pentyl, or cyclopentyl groups at N9 resulted in increased antiproliferative activity compared to N9-tetrahydropyranyl derivatives. Compound $\mathbf{2 3}$ inhibited the assembly of porcine tubulin in vitro in a dose-dependent manner and caused the dose-dependent accumulation of HCT116 and SW620 cells in the $\mathrm{G}_{2} / \mathrm{M}$ cell cycle phase (the highest concentration tested was $75 \mathrm{nM}$ in cell cycle analysis experiments). Moreover, compound 23 displayed no activity against a panel of 420 kinases when tested at a concentration of 
$1 \mu \mathrm{M}$, suggesting its specific tubulin inhibitory activity. This compound displayed high activity against a panel of other colorectal cancer cell lines (SW620, $\mathrm{IC}_{50}=60 \mathrm{nM}$; CT26, $\mathrm{IC}_{50}=45.5 \mathrm{nM} ;$ SW480, IC $50=64.5 \mathrm{nM}$; DLD-1, IC $50=135.5 \mathrm{nM}$; HCT-15, $\mathrm{IC}_{50}=61.0 \mathrm{nM}$, and HT29, $\left.\mathrm{IC}_{50}=71.0 \mathrm{nM}\right)$. In a murine xenograft model employing HCT116 cells, oral administration of compound 23 at 40 or $80 \mathrm{mg} / \mathrm{kg}$ once daily for 28 days resulted in tumor growth inhibition (TGI) of $39.9 \%$ and $71.6 \%$ compared to the control group, respectively, while the TGI for the group receiving oral capecitabine at $540 \mathrm{mg} / \mathrm{kg}$ once daily for 28 days was $61.6 \%$.

In a further extension of the work described above, Hu et al. synthesized a series of derivatives based on compound 23 [44]. These target compounds displayed high potency against CT26, SW620, and HCT116 colorectal cancer cell lines. Compound 24 displayed IC $_{50}$ values of $0.022,0.009$, and $0.058 \mu \mathrm{M}$ against the cell lines mentioned above, respectively, while SKLB0565 (25) exhibited $\mathrm{IC}_{50}$ values of $0.057,0.040$, and $0.021 \mu \mathrm{M}$, respectively, against these cell lines. Compound 25 displayed concentration-dependent inhibition of porcine tubulin assembly and also caused concentration-dependent accumulation of HCT116 and SW620 cells in the $\mathrm{G}_{2} / \mathrm{M}$ cell cycle phase at 25-100 nM concentrations. In addition, this compound displayed activity against other colorectal cancer cell lines (SW480, $\mathrm{IC}_{50}=0.081 \mu \mathrm{M}$; SW48, $\mathrm{IC}_{50}=0.015 \mu \mathrm{M}$; DLD-1, $\mathrm{IC}_{50}=0.074 \mu \mathrm{M}$; HCT-15, $\mathrm{IC}_{50}=0.029 \mu \mathrm{M}$; and $\mathrm{HT} 29, \mathrm{IC}_{50}=0.029 \mu \mathrm{M}$ ). At concentrations of $50 \mathrm{nM}$ and $100 \mathrm{nM}$, compound 25 displayed in vitro anti-vascular activity in HUVECs in wound healing and capillary tube formation assays.

Huang et al. designed new purine and pyrimidine molecules based on the structural modification of apcin (26), a substituted 2-aminopyrimidine compound [45]. Compound 26 is a specific inhibitor of Cdc20, a protein which activates the key E3 ubiquitin ligase $\mathrm{APC} / \mathrm{C}$ that controls cell cycle progression; Cdc20 is overexpressed in several cancers (see Reference [46] for a review of Cdc20 as an anticancer target). Of the compounds tested, 27 and $\mathbf{2 8}$ generally displayed the greatest potency against cancer cell lines, with $\mathrm{IC}_{50}$ values in the range between 0.2-1.8 $\mu \mathrm{M}$ against MCF-7, A375, A549, OVCAR-3, Caov-3, HepG2, and HeLa cancer cell lines. By comparison, the $\mathrm{IC}_{50}$ values of $\mathbf{2 6}$ were greater than $193 \mu \mathrm{M}$ against these cell lines. In terms of the SAR for the purine-containing compounds against cancer cell lines, substitution with fluorine rather than chlorine at $\mathrm{C} 2$ of the purine ring system resulted in greater potency. Compound 29 displayed a $\mathrm{K}_{\mathrm{d}}=49 \mu \mathrm{M}$ for Cdc20 as measured by surface plasmon resonance (SPR), while the binding of $\mathbf{2 6}$ and $\mathbf{2 8}$ to Cdc20 was weaker $\left(\mathrm{K}_{\mathrm{d}}\right.$ values of $123 \mu \mathrm{M}$ and $119 \mu \mathrm{M}$, respectively). Compounds $29(30 \mu \mathrm{M})$ and $28(0.3 \mu \mathrm{M})$ both blocked the exit of HepG2 cells from mitosis as assessed by the increased levels of phosphohistone H3, a marker of mitosis. Given the potency of 28 compared to 29, the authors hypothesized that the former compound could possess an additional mechanism of action. Compound 28 was shown to dose-dependently ( 3 to $300 \mu \mathrm{M}$ ) inhibit the assembly of porcine tubulin in vitro, consistent with this molecule acting as an antimicrotubule agent.

Plinabulin (30), a microtubule targeting anticancer drug candidate with multiple proposed mechanisms of action, has undergone multiple clinical trials [47]. Ding et al. designed and synthesized new compounds based on a co-crystal structure of plinabulin bound to tubulin [48]. Compound 31 displayed IC $_{50}$ values against NCI-H460, HepG2, HCT116, MCF-7, and HeLa cells of 4.0, 3.0, 3.8, 9.0, and 8.4 nM, while plinabulin displayed $\mathrm{IC}_{50}$ values of $26.2,4.8,6.0,29.8$, and $9.0 \mathrm{nM}$ against these cancer cell lines. At concentrations of $5 \mu \mathrm{M}$, compound 31 inhibited tubulin polymerization by $39.7 \%$, while plinabulin and compound 32 (which exhibited an $\mathrm{IC}_{50}$ value of $3.8 \mathrm{nM}$ against NCI-H460 cells) displayed $13.5 \%$ and $47.3 \%$ inhibition, respectively. Compounds 31 and 32 also disrupted microtubules in NCI-H460 cells at a concentration of $5 \mathrm{nM}$ as assessed by immunofluorescence.

\section{Imidazoles as Kinase Inhibitors}

Protein kinases play an important role in the progression of various cellular processes, such as growth, differentiation, and apoptosis. These enzymes are classified as 
serine/threonine or tyrosine kinases based on the identity of the phosphorylated amino acid. While expression of these kinases is strictly controlled in normal cells, overexpression of serine/threonine and tyrosine kinases has been reported in a variety of cancers. Thus, the inhibition of these kinases with small molecules can provide a strategy for cancer treatment. Tyrosine kinases discussed below include vascular endothelial growth factor receptor (VEGFR), Src family kinase (SFK), and activin receptor-like kinase 5 (ALK5). Serine-threonine kinases mentioned in this section include checkpoint kinases 1 and 2 (Chk1 and Chk2), rapidly accelerated fibrosarcoma (RAF) kinase, cyclin-dependent kinase (CDK), Polo like kinase 1 (PLK1), Aurora kinase (AURK), and AKT. Phosphatidylinositol3-kinase (PI3K) is a lipid kinase that transforms phosphatidylinositol $(4,5)$-bisphosphate into the second messenger phosphatidylinositol $(3,4,5)$-trisphosphate. A variety of drugs targeting receptor tyrosine kinases, non-receptor tyrosine kinases and serine-threonine kinases have been developed (reviewed in Reference [49]), and the discovery of selective kinase inhibitors continues to be the focus of many medicinal chemists.

\subsection{Tyrosine Kinase Inhibitors}

\subsubsection{Vascular Endothelial Growth Factor Receptor (VEGFR) Inhibitors}

The formation of new blood vessels (angiogenesis) is required for cell and tissue growth. Cancer growth and metastasis depend directly on tumor angiogenesis and vascularization. Vascular endothelial growth factor (VEGF) is a signaling protein that plays an important role in cellular proliferation, survival, and migration during the development of new vasculature, and most human cancers display up-regulated expression of VEGF mRNA. VEGF mediates its biological effects through binding to VEGF receptors (VEGFRs), tyrosine kinases that dimerize and become autophosphorylated upon binding VEGF, triggering a range of downstream effects (for recent reviews of VEGF and VEGF signaling, see references $[50,51])$. Various therapeutic agents, such as monoclonal antibodies (bevacizumab) and small molecules (sunitinib and sorafenib), have been approved as VEGFR inhibitors, but side effects, such as hypertension, are associated with the small molecule agents [52]. New VEGFR inhibitors with an improved therapeutic window are, thus, being sought.

Yuan et al. reported several compounds possessing a benzoxazole/benzimidazole scaffold displaying potent in vitro antiproliferative activity against HUVEC, HepG2, MDA-MB231, and A549 cell lines through the inhibition of VEGFR-2 kinase [53]. These compounds showed potent activity against VEGFR-2 expressing cell lines (HepG2 and HUVEC), but they were less active on EGFR expressing cell lines (MDA-MB-231 and A549). Compounds 33 and 34 (see Figure 4 for structures of compounds 33-43) displayed activity against HUVECs ( $\mathrm{IC}_{50}$ values of 1.47 and $3.21 \mu \mathrm{M}$ ) and HepG2 cells ( $\mathrm{IC}_{50}$ values of 2.57 and $5.56 \mu \mathrm{M}$ ). The compounds possessing a benzimidazole scaffold were generally more active against these cell lines than benzoxazole-containing compounds. Compound 33 displayed an $\mathrm{IC}_{50}$ value of $51.4 \mathrm{nM}$ against VEGFR-2, while inhibiting EGFR by $58.3 \%$, when tested at a concentration of $1 \mu \mathrm{M}$. Compound 33 displayed little or no activity on a panel of five other kinases (PGDFR- $\alpha$ and $\beta$, FLT1, FLT4, and MET). Moreover, compound 33 displayed $56.4 \%$ inhibition against LO2 (normal human liver) cells at a concentration of $10 \mu \mathrm{M}$. Dose-dependent anti-angiogenic activity was observed with compound 33 using a chick chorioallantoic membrane assay $(79 \%$ at $10 \mathrm{nM} / \mathrm{eggs})$. Western blotting studies showed that compound 33 inhibited VEGFR-2 phosphorylation in HUVECs at concentrations of $2 \mu \mathrm{M}$ and $4 \mu \mathrm{M}$. 
<smiles>[R]c1ccc(CC(=O)Nc2ccc3[nH]c(-c4ccc(Cl)cc4)nc3c2)cc1</smiles>

33: $\mathrm{R}=\mathrm{OMe}$

34: $\mathrm{R}=\mathrm{Me}$<smiles>[R][R]([B])=C([B])C</smiles><smiles>CN(C)CCOc1ccc(Nc2ncc3nc(Sc4ccc(F)cc4)n(C4CCOCC4)c3n2)cc1</smiles><smiles>Cn1c(=O)c2[nH]c(SCC(=O)Nc3ccc(C(=O)/C=C/c4ccc(Cl)cc4)cc3)nc2n(C)c1=O</smiles><smiles>[R]c1cc([R])c(CNc2cccc(-c3nc4ccccc4[nH]3)c2)c([R])c1</smiles>

35: $\mathrm{R}^{1}=\mathrm{H}, \mathrm{R}^{2}=\mathrm{NO}_{2}$

36: $\mathrm{R}^{1}=\mathrm{Cl}, \mathrm{R}^{2}=\mathrm{H}$<smiles>CN(C)C1CCN(c2ccc(Nc3ncc4nc(Sc5ccccc5)n(C5CCOCC5)c4n3)cc2)CC1</smiles><smiles>CN1CCN(c2ccc(Nc3ncc4nc(Nc5ccccc5)n(C5CCN(S(=O)(=O)C6CC6)C5)c4n3)cc2)CC1</smiles>

41<smiles>COc1ccc(/C(CSc2nc3c([nH]2)c(=O)n(C)c(=O)n3C)=N/O)cc1</smiles>

Figure 4. Imidazole-containing tyrosine kinase inhibitors targeting VEGFR-2 and EGFR reported in the literature (compounds 33-43).

Mostafa et al. synthesized 2-phenyl benzimidazole derivatives as potential anticancer agents that were evaluated against the MCF-7 cell line and also against VEGFR-2 [54]. Of the target compounds, 35 and 36 displayed $\mathrm{IC}_{50}$ values of 3.37 and $6.30 \mu \mathrm{M}$ against MCF-7 cells, respectively, while the $\mathrm{IC}_{50}$ value of the standard drug doxorubicin was $4.17 \mu \mathrm{M}$. When these compounds were tested against three normal human cell lines (breast epithelial (MCF-10F), skin fibroblast (BJ), and lung fibroblast (MRC-5) cells), $\mathrm{IC}_{50}$ values ranged from $17.3-79.3 \mu \mathrm{M}$, while the $\mathrm{IC}_{50}$ value for doxorubicin against these cells ranged from 15.2-22.6 $\mu \mathrm{M}$. In an ELISA-based VEGFR assay, these compounds displayed $\mathrm{IC}_{50}$ values of 6.7 and $6.9 \mathrm{nM}$, respectively, while the reference drug sorafenib displayed an $\mathrm{IC}_{50}$ value of $7.6 \mathrm{nM}$.

\subsubsection{Epidermal Growth Factor Receptor (EGFR) Inhibitors}

The epidermal growth factor receptor (EGFR) is a receptor tyrosine kinase (RTK) known to play an important role in the physiology of epithelial cells by regulating several 
cellular processes including cell survival and differentiation. Activation of EGFR results in signaling through several pathways, including the PI3K/AKT and Ras/MAPK pathways. Mutation or overexpression of EGFR occurs in many cancers, including lung cancer and glioblastoma, and the EGFR is the target of small molecule inhibitor drugs, such as erlotinib and gefitinib, as well as EGFR-binding antibodies (see Reference [55] for a review of the roles of the EGFR in cancer). Thus, the development of new EGFR-directed agents continues to be of interest.

Akhtar et al. synthesized new benzimidazole-pyrazole derivatives as potential anticancer agents targeting EGFR [56]. Among the synthesized compounds, 37 and 38 displayed the greatest inhibition of EGFR phosphorylation in the KB cell line as assessed by ELISA, exhibiting $\mathrm{IC}_{50}$ values of $0.97 \mu \mathrm{M}$ and $1.7 \mu \mathrm{M}$, respectively. The reference standard gefitinib exhibited an $\mathrm{IC}_{50}$ value of $0.011 \mu \mathrm{M}$ in this assay. Of the four cancer cell lines examined, compounds 37 and 38 displayed the greatest antiproliferative activity against A549 cells, with $\mathrm{IC}_{50}$ values of 2.2 and $2.8 \mu \mathrm{M}$, respectively. When incubated with A549 cells at 5 and $10 \mu \mathrm{M}$ for $24 \mathrm{~h}$, compound 37 caused a dose-dependent increase in the percentage of cells in the $\mathrm{G}_{2} / \mathrm{M}$ cell cycle phase. No mortality was observed $24 \mathrm{~h}$ post-administration when a single $500 \mathrm{mg}$ dose of compound 37 was given to female albino rats by oral gavage.

Hei et al. synthesized new 2,9-disubstituted purine derivatives also containing 8phenylthio and 8-phenylsulfinyl substitutions as potential antiproliferative agents against A549, H1975, and HCC827 human lung adenocarcinoma cell lines and tested these compounds for their EGFR inhibitory activities [57]. These compounds displayed high activity against the HCC827 cell line, which harbors a deletion mutation that activates EGFR, compared to A549 cells (possessing wild type EGFR) and H1975 cells (harboring EGFR T790M and L858R mutations). Compounds 39 and 40 exhibited $\mathrm{IC}_{50}$ values of $29.4 \mathrm{nM}$ and $47.8 \mathrm{nM}$ against the HCC 827 cell line and were at least two orders of magnitude less potent against A549 and H1975 cells. Among 8-phenylthio and 8-phenylsulfinyl purines with the same substitutions at positions 2 and 9, the former compounds were in general more active against HCC827 cells. In an EGFR enzymatic assay against EGFR ${ }^{\mathrm{WT}}$, EGFR ${ }^{\mathrm{L} 858}$, $\mathrm{EGFR}^{\mathrm{L} 858 \mathrm{R} / \mathrm{T} 790 \mathrm{M}}$, and EGFR ${ }^{\mathrm{L} 858 \mathrm{R} / \mathrm{T} 790 \mathrm{M} / \mathrm{C} 797 \mathrm{~S}}$, compounds 39 and 40 displayed $\mathrm{IC}_{50}$ values of 1.6, 1.9, 104, $331 \mathrm{nM}$ and 2.5, 1.2, 189, $114 \mathrm{nM}$, respectively. In Western blotting studies with compound 39 in the HCC827 cell line, a dose-dependent inhibition of EGFR phosphorylation was observed at concentrations of 39 ranging from $0.1-3.0 \mu \mathrm{M}$. When evaluated in an HCC827 xenograft model in nude Balb/c mice, compound 39 (5 mg/ $\mathrm{kg}$ administered orally once a day for 20 days) significantly reduced tumor volume and tumor weight compared to the vehicle control group.

In a follow-up to the previous study, Lei et al. synthesized a series of 29 new purine derivatives targeting the mutant EGFR tyrosine kinases which have resulted in resistance to first, second, and third generation EGFR inhibitors [58]. The target compounds were highly active against the HCC827 cancer cell line, with $\mathrm{IC}_{50}$ values ranging from $0.00088-1.81 \mu \mathrm{M}$. Compound 41 displayed high potency against HCC827, H1975, A549, and A431 cancer cell lines, with $\mathrm{IC}_{50}$ values in the range between $0.0016-1.67 \mu \mathrm{M}$. The presence of a sulfonamide group on the substituent at the N9 position of the purine core resulted in high potency in this group of analogs, although activity against HCC827 cells was retained upon replacement of a pyrrolidinyl sulfonyl moiety with phenyl acetamide or piperidinyl

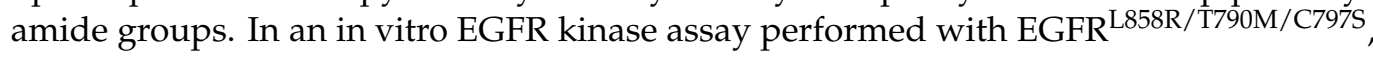
compound 41 displayed an $\mathrm{IC}_{50}$ value of $40 \mathrm{nM}$, while the third generation EGFR inhibitor osimertinib displayed an $\mathrm{IC}_{50}$ value of $110 \mathrm{nM}$. Western blotting studies with compound 41 and other analogs in HCC827, H1975, and A549 cells showed that the compounds exhibited dose-dependent inhibition of EGFR phosphorylation and AKT phosphorylation at $0.1-10-\mu \mathrm{M}$ concentrations.

A series of 20 xanthine/chalcone hybrids were prepared and evaluated as potential EGFR-directed anticancer compounds [59]. While these molecules were not toxic to the MCF-10A human mammary gland epithelial cell line, $\mathrm{IC}_{50}$ values for these compounds ranged from 1.0 to $11.6 \mu \mathrm{M}$ against A549, PANC-1, HT29, and MCF-7 cancer cells. By 
comparison, the standard drug doxorubicin displayed $\mathrm{IC}_{50}$ values ranging from 0.90 to $1.41 \mu \mathrm{M}$ against these cell lines. In terms of the antiproliferative structure-activity relationship, the 1,3-dimethylxanthine derivatives were generally more potent than the 1-methylated xanthines. The six most active compounds in the antiproliferative assay were examined for their inhibition of EGFR kinase in a cell-free assay. $\mathrm{IC}_{50}$ values ranged from $0.3-1.6 \mu \mathrm{M}$ in this assay, while the standard compound staurosporin exhibited an $\mathrm{IC}_{50}$ value of $0.4 \mu \mathrm{M}$. Compound 42 , which displayed $\mathrm{IC}_{50}$ values ranging from 1.3-1.8 $\mu \mathrm{M}$ against the cancer cell lines and an IC 50 value of $0.3 \mu \mathrm{M}$ against EGFR in vitro, also caused increased expression of the apoptotic marker caspase-3 in PANC-1 cells.

Hisham et al. synthesized substituted xanthine derivatives as EGFR-targeting anticancer agents and tested their antiproliferative activity against PANC-1, HT29, A549, and MCF-7 cancer cells and MCF-10A normal human breast epithelial cells [60]. These compounds displayed $\mathrm{IC}_{50}$ values in the range between $0.8-11.9 \mu \mathrm{M}$ against the cancer cell lines, while the authors reported that all compounds were non-cytotoxic to MCF-10A cells. Compound 43 displayed $\mathrm{IC}_{50}$ values $\leq 1.7 \mu \mathrm{M}$ against these cancer cell lines and was most active against MCF-7 cells $\left(\mathrm{IC}_{50}=0.8 \mu \mathrm{M}\right)$. In terms of the SAR against cancer cell lines, compounds containing an oxime moiety at the benzylic position generally possessed higher antiproliferative activity compared to the corresponding ketone-containing precursors. Of these target molecules, compound 43 displayed the most potent EGFR inhibitory activity $\left(\mathrm{IC}_{50}=0.32 \mu \mathrm{M}\right)$, while the standard drug erlotinib displayed an $\mathrm{IC}_{50}$ value of $0.08 \mu \mathrm{M}$ in this assay. In PANC-1 cells, the most potent antiproliferative compounds increased the expression of caspase- 3 by 4 - to 8 -fold with respect to controls.

Srour et al. synthesized thiazole-benzimidazole derivatives as potential anticancer agents directed against EGFR [61]. These compounds displayed IC 50 values against EGFR kinase in the range between 71.7-1235 nM. Compounds that showed potent activity against EGFR were evaluated for their cytotoxicity to the MCF-7 cell line. Of these, compounds $\mathbf{4 4}$ and 45 (see Figure 5 for structures of compounds 44-56) possessed the greatest potency against the MCF-7 cells, exhibiting $\mathrm{IC}_{50}$ values of $6.30 \mu \mathrm{M}$ and $5.96 \mu \mathrm{M}$, respectively, while the $\mathrm{IC}_{50}$ of the standard drug erlotinib was $4.15 \mu \mathrm{M}$ against this cell line. Considering that EGFR inhibitory activity did not directly correlate with activity against MCF-7 cells for these molecules, the authors speculated that other mechanisms of action may also be responsible for their anticancer activity. When tested at its $\mathrm{IC}_{50}$ concentration in MCF-7 cells, compound 44 caused the accumulation of these cells in the pre- $G_{1}$ and $G_{2} / M$ cell cycle phases. At this same concentration, compound $\mathbf{4 4}$ increased the percentage of early and late apoptotic cells compared to the DMSO treated controls as assessed by annexin $\mathrm{V} /$ propidium iodide staining. Moreover, at its $\mathrm{IC}_{50}$ concentration, 44 increased the levels of the pro-apoptotic markers p53, Bax, and caspase-3 by 9.85-, 4.95-, and 12.28-fold in MCF-7 cells compared to control, while the anti-apoptotic marker Bcl-2 was decreased by approximately 2-fold in treated MCF-7 cells.

Kalra et al. synthesized imidazole and purine derivatives as EGFR-directed anticancer agents and tested them for antiproliferative activity against MDA-MB-231, T47D, MCF-7, HT29 and A549 cancer cell lines [62]. Purine target compounds 46 and 48 displayed IC 50 values of 1.22 and $2.29 \mu \mathrm{M}$ against the MDA-MB-231 cell line in an MTT assay. Purine 47 exhibited $\mathrm{IC}_{50}$ values in the range between 2.29-9.96 $\mu \mathrm{M}$ against these five cancer cell lines, showing the most potent activity against A549 cells. Counter-screening of compounds $46-48$ at a concentration of $10 \mu \mathrm{M}$ indicated that they were non-cytotoxic to normal human peripheral blood mononuclear cells (HPBMCs) and normal breast cells (HBL-100). Although selected imidazoles showed good activity against A549 cells, they exhibited greater toxicity than the purines to one or the other of the normal cell lines. Derivatization of compound 47 gave $\mathbf{4 9}$, which displayed slightly greater potency than 47 ( $\mathrm{IC}_{50}$ values for compound 49 were in the range $1.98-4.07 \mu \mathrm{M}$ against these five cancer cell lines). Compounds 47, 48, and 49 displayed $\mathrm{IC}_{50}$ values of 617,710 , and $236 \mathrm{nM}$, respectively, against EGFR-mediated phosphorylation, while these compounds exhibited $\mathrm{IC}_{50}$ values $>500 \mathrm{nM}$ against $\mathrm{CDK} 2, \mathrm{CDK} 4$, and CDK6. 

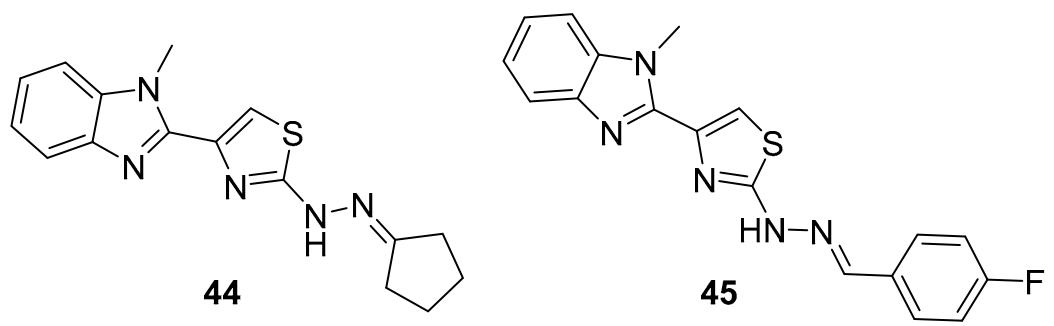<smiles>[R]c1ccc(-c2nc(C(N)=O)c3ncn(-c4ccc(F)cc4)c3n2)cc1[R]</smiles>

46: $\mathrm{R}^{1}=\mathrm{OMe}, \mathrm{R}^{2}=\mathrm{H}$

47: $\mathrm{R}^{1}=\mathrm{R}^{2}=\mathrm{OMe}$

48: $\mathrm{R}^{1}=i-\mathrm{Pr}, \mathrm{R}^{2}=\mathrm{H}$<smiles>COc1ccc(-c2nc(C(N)=O)c3ncn(-c4ccc(N5CCN(C)CC5)c([N+](=O)[O-])c4)c3n2)cc1OC</smiles>

49

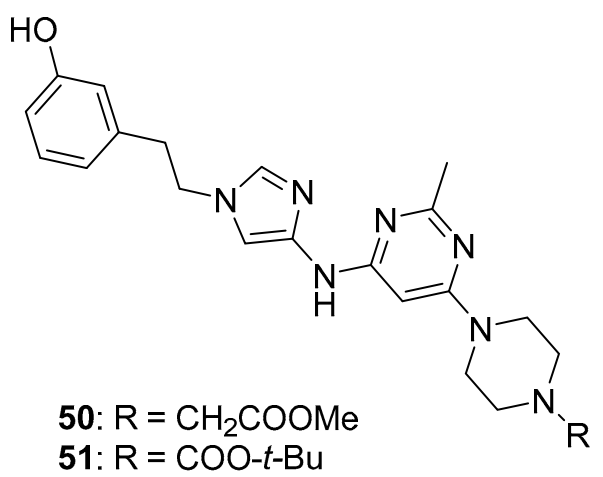<smiles>[R]c1ccc(Nc2nc(Nc3ccc(N4CCN(C)CC4)cc3)nc3c2ncn3CC2CC2)cc1F</smiles>

55: $\mathrm{R}=\mathrm{H}$

56: $R=F$

52: $\mathrm{R}^{1}=t-\mathrm{Bu}, \mathrm{R}^{2}=\mathrm{R}^{3}=\mathrm{R}^{4}=\mathrm{OMe}$

53: $R^{1}=$ cyclohexyl, $R^{2}=R^{3}=O M e, R^{4}=H$

54: $\mathrm{R}^{1}=t-\mathrm{Bu}, \mathrm{R}^{2}=\mathrm{R}^{3}=\mathrm{OMe}, \mathrm{R}^{4}=\mathrm{H}$

Figure 5. Additional imidazole-containing tyrosine kinase inhibitors and candidate inhibitors reported in the literature targeting EGFR, SFKs, and Bcr-Abl/Btk (compounds 44-56).

\subsubsection{Src Family Kinase (SFK) Inhibitors}

The SFKs are nonreceptor tyrosine kinases that play important roles in the regulation of cell cycle progression, apoptosis, transcription, migration, differentiation, development, and survival. Since SFKs are downstream of oncogenic drivers, such as EGFR, and are also part of pathways that regulate survival and proliferation, the inhibition of SFKs provides a good strategy for the discovery of new anticancer candidates (see Reference [63] for a review of SFKs and SFK inhibitors).

Francini et al. described the synthesis of new aminoimidazole anticancer candidates that inhibit SFKs [64]. The target compounds were screened against K562, U87 (glioblastoma multiforme (GBM)), and SH-SY5Y (neuroblastoma) cancer cell lines. Compounds 50 and 51 displayed antiproliferative activities with $\mathrm{IC}_{50}$ values of 8.6 and $7.8 \mu \mathrm{M}$ against SH-SY5Y cells, 11.7 and $18.9 \mu \mathrm{M}$ against K562 cells, and 12.6 and $13.3 \mu \mathrm{M}$ against U87 cells, respectively. These two compounds displayed $\mathrm{IC}_{50}$ values against SFKs (Src, Fyn, Lyn, and Yes) in the range between 3-50 nM. In terms of the SAR for these compounds, molecules 
displaying ortho or meta hydroxy substitutions on the phenyl ring exhibited the highest potency against SFKs in vitro.

Rezaei et al. prepared a series of diphenylimidazo-quinoxalinamine derivatives as anticancer candidates [65]. Compounds 52, 53, and 54 showed the greatest potencies against the $\mathrm{K} 562$ cell line $\left(\mathrm{IC}_{50}\right.$ values of $9.77,12.02$, and $15.84 \mu \mathrm{M}$, respectively). Evaluation of compounds 52-54 against the tyrosine kinases c-Src, LCK (an SFK), and ABL1 (see below) revealed that only compound 54 possessed activity against ABL1 and $c$-Src with $\mathrm{IC}_{50}$ values of 5.25 and $3.94 \mu \mathrm{M}$, respectively, while this compound was not active against LCK.

\subsubsection{Bcr-Abl and Bruton's Tyrosine Kinase (BTK) Inhibitors}

$\mathrm{Bcr}-\mathrm{Abl}$ is a tyrosine kinase that is known to play a major role in chronic myelogenous leukemia (CML), while Bruton's tyrosine kinase (BTK) is implicated in B-cell malignancies (chronic lymphocytic leukemia and non-Hodgkin lymphomas). The expression of the Bcr-Abl fusion protein causes dysregulation of kinase activity, while BTK plays a central role in B cell receptor signaling pathways. Thus, Bcr-Abl and BTK are important targets against leukemia. Drugs, such as imatinib, nilotinib (4), and ponatinib (5), are known to target Bcr-Abl, while ibrutinib targets the BTK pathway (please see Reference [66] for a review of Bcr-Abl inhibitors and Reference [67] for a review of anticancer drugs targeting BTK). Bertrand et al. synthesized 2,6,9-trisubstituted purine derivatives as candidate dual $\mathrm{Bcr}-\mathrm{Abl} / \mathrm{Btk}$ inhibitors [68]. Most of the target compounds synthesized displayed $\mathrm{IC}_{50}$ values below $4 \mu \mathrm{M}$ against $\mathrm{Abl}$ and Btk. Among these, compounds 55 and 56 displayed the greatest potency, both exhibiting $\mathrm{IC}_{50}$ values of $0.040 \mu \mathrm{M}$ against $\mathrm{Abl}$ and 0.66 and $0.58 \mu \mathrm{M}$ against Btk, respectively, while showing little activity against $\mathrm{Cdk}-2 /$ cyclin $\mathrm{E}\left(\mathrm{IC}_{50}\right.$ values of 24.0 and $18.5 \mu \mathrm{M}$, respectively). Compounds 55 and 56 displayed $\mathrm{IC}_{50}$ values in the range between 0.77-8.89 $\mu \mathrm{M}$ against K562, HL-60, CEM, Ramos, MV4-11, and MCF-7 cells. Western blotting analysis revealed that the expression of the Bcr-Abl substrates pSTAT5 and pCRKL were decreased in a dose-dependent manner when compound $\mathbf{5 5}$ was incubated with K562 cells at concentrations ranging from 0.1-10 $\mu \mathrm{M}$. Moreover, exposure to compound 55 at concentrations of 5, 10, and $20 \mu \mathrm{M}$ reduced the levels of pBTK (Y223) synthesized through autophosphorylation and also lowered the levels of downstream targets pERK1/2, pPLC $\gamma 2$, and pAKT in Ramos cells stimulated with Ig-M in a dosedependent manner.

\subsection{Serine-Threonine Kinase Inhibitors}

\subsubsection{Activin Receptor-Like Kinase 5 (ALK5) Inhibitors}

TGF- $\beta$ modulates various cellular processes including cell proliferation, migration, differentiation and apoptosis. In a process that involves TGF- $\beta$ binding to the TGF- $\beta$ receptor-2 (T $\beta$ RII), TGF- $\beta$ receptor-1 (ALK5) is activated and phosphorylates Smad 2 and Smad3, which then combine with Smad4 to modulate transcription. Although TGF- $\beta$ acts as a tumor suppressor early in tumor development, it acts as a tumor promotor later in tumorigenesis. Thus, ALK5 inhibitors have been investigated as potential anticancer therapeutics (see Reference [69] for a review of TGF- $\beta$ signaling and opportunities presented by this process for anticancer therapeutics). A series of novel benzothiadiazole-imidazole and thienopyridine-imidazole derivatives were synthesized by Guo et al. and evaluated for activity against ALK5 [70]. These compounds inhibited ALK5 kinase activity with $\mathrm{IC}_{50}$ values in the range between $0.008-0.043 \mu \mathrm{M}$, with compound 57 (see Figure 6 for structures of compounds 57-69) displaying the highest potency against ALK5. Compound 57 displayed 19-fold selectivity for ALK5 compared to p38 $\alpha$ MAP kinase, which possesses a kinase domain similar to that of ALK5. Compound 58 exhibited an $\mathrm{IC}_{50}$ value of $7.70 \mu \mathrm{M}$ against $\mathrm{p} 38 \alpha \mathrm{MAP}$ kinase and $0.022 \mu \mathrm{M}$ against ALK5 (selectivity of 350-fold). In terms of the SAR, imidazole-containing compounds possessing a benzothiadiazole ring were in general slightly more active compared to those bearing a thienopyridine ring, while substitutions on the aniline moiety had little effect on activity. Western blotting analysis revealed that treatment of HepG2 and SPC-A1 cells with $0.1 \mu \mathrm{M}$ and $0.5 \mu \mathrm{M}$ concentrations 
of compound 57 resulted in the inhibition of TGF- $\beta 1$-stimulated phosphorylation of Smad2. In a wound healing assay, treatment with compound 57 at $2 \mu \mathrm{M}$ and $10 \mu \mathrm{M}$ inhibited TGF- $\beta 1$-induced migration of HUVECs.<smiles>[R]c1ccc(NCc2nc(-c3ccc4nsnc4c3)c(-c3cccc(C)n3)[nH]2)cc1[R]</smiles>

$57 ; \mathrm{R}^{1}=\mathrm{H}, \mathrm{R}^{2}=\mathrm{F}$ 58; $R^{1}=M e, R^{2}=H$<smiles>N#Cc1c(Nc2ccc(-c3nc4cc(C(N)=O)ccc4[nH]3)cc2)nc(=S)[nH]c1-c1ccc([N+](=O)[O-])cc1</smiles>

62<smiles>[R]c1cc([R])c(C(=O)NCCNc2nccc(-c3c(-c4cccc(F)c4)nc4sccn34)n2)c([R])c1</smiles>

66: $\mathrm{R}^{1}=\mathrm{Cl}, \mathrm{R}^{2}=\mathrm{H}$

67: $R^{1}=H, R^{2}=F$<smiles>[R]c1ccc2[nH]c(-c3ccc(Oc4c(/C=N/NC([X])N)c(C)nn4-c4ccccc4)cc3)nc2c1</smiles>

59: $X=S, R=\mathrm{NO}_{2}$

60: $\mathrm{X}=\mathrm{O}, \mathrm{R}=\mathrm{CONH}_{2}$

61: $X=O, R=\mathrm{NO}_{2}$<smiles>[R]OCCOc1nc([X])c(C#N)c(-c2ccc(F)cc2)n1</smiles>

63: $\mathrm{X}=\mathrm{S}, \mathrm{R}=\mathrm{CONH}_{2}$

64: $\mathrm{X}=\mathrm{O}, \mathrm{R}=\mathrm{CONH}_{2}$

65: $\mathrm{X}=\mathrm{O}, \mathrm{R}=\mathrm{COOH}$<smiles>[R]c1ccc(S(=O)(=O)NCCCNc2nccc(-c3c(-c4cccc(F)c4)nc4sccn34)n2)cc1</smiles>

68: $\mathrm{R}=\mathrm{H}$

69: $\mathrm{R}=\mathrm{Br}$

Figure 6. Imidazole-containing inhibitors of ALK5, Chk2, and BRAF reported in the literature (compounds 57-69).

\subsubsection{Inhibitors of Checkpoint Kinases}

The checkpoint kinases (Chk1 and Chk2) are intracellular serine/threonine protein kinases which play an important role in the DNA damage response pathway limiting cell cycle progression in the presence of such damage. Chk1 is activated by ATR (ataxia telangiectasia mutated and Rad3-related serine/threonine kinase), while Chk2 is activated by ATM (ataxia telangiectasia mutated serine/threonine kinase; see references [71,72] for reviews focused on these kinases). Activated checkpoint kinases are responsible for downstream phosphorylation processes causing cell-cycle arrest in the presence of DNA damage, leading to DNA repair. Considering the roles played by Chk1 and Chk2 in the response to DNA damage, inhibition of Chk1 and/or Chk2 may improve the efficacy of anticancer agents that damage DNA and are, thus, an attractive target for the development of new anticancer drugs (see Reference [73] for a review of Chk1 and Chk2 inhibition in cancer). The development of Chk inhibitors, such as UCN-01, LY2603618, PF477736, AZD7762, and MK-8776, have provided a path toward the discovery of new molecules targeting checkpoint kinases [71,73]. 
Analogs bearing a pyrazole-benzimidazole motif were synthesized by Galal et al. and were tested for their cytotoxic activity on MCF-7, HeLa, and HepG2 cell lines and were also tested in vitro for Chk2 inhibition [74]. Chk2 inhibitory activity was in the range 9.95-65.07 $\mathrm{nM}$ for these molecules. Compounds 59 and 60 were among the most potent of these derivatives against Chk2, exhibiting $\mathrm{IC}_{50}$ values of 11.49 and $11.13 \mathrm{nM}$, respectively. Assays on HepG2, HeLa, MCF-7 and baby hamster kidney (BHK) cells showed that compound 60 displayed a GI 50 value of $6.5 \mu \mathrm{M}$ against MCF-7 cells, while compounds 61 and 59 exhibited $\mathrm{GI}_{50}$ values of $11.7 \mu \mathrm{M}$ and $6.6 \mu \mathrm{M}$ against HeLa cells, respectively. Some of these analogs enhanced the activity of the cytotoxic anticancer agents doxorubicin and cisplatin in MCF-7 cells, while some did not. For example, a potentiation index of 276 was determined for the combination of doxorubicin with compound 61 in MCF-7 cells, while no potentiation was observed for doxorubicin paired with target compounds $\mathbf{5 9}$ and 60. Of the compounds evaluated, $\mathbf{6 1}$ was the least toxic in vivo and was, thus, further tested alone and in combination with doxorubicin in an MNU-induced breast cancer model in rats. Serum Chk2 activity was lower in MNU-induced animals receiving compound $\mathbf{6 1}$ at an oral dose of $50 \mathrm{mg} / \mathrm{kg} /$ day for 10 days compared to MNU-treated animals that did not receive this compound, and the serum of $\mathrm{MNU}$-induced animals receiving a combination of doxorubicin and compound $\mathbf{6 1}$ at this same dose displayed lower Chk2 activity compared to $\mathrm{MNU}$-induced rats receiving doxorubicin alone.

These authors extended the work described above by synthesizing derivatives in which the pyrazole moiety was changed to pyrimidine [75]. These new derivatives inhibited Chk2 activity with $\mathrm{IC}_{50}$ values ranging from 5.55-46.2 nM. Compounds 62 and 63 exhibited $\mathrm{IC}_{50}$ values of 6.60 and $6.24 \mu \mathrm{M}$, respectively, against MCF-7 cells. Target compounds bearing a $\mathrm{C} 5$ amide and either an ether or amine linkage at the para position of the phenyl ring at the $\mathrm{C} 2$ position of the benzimidazole core potentiated the activity of doxorubicin and cisplatin against MCF-7 cells. On the other hand, C5 carboxylic acid compound 65 and $\mathrm{C} 5$ amide compounds with a thioether linkage at the para position of the phenyl ring at the $\mathrm{C} 2$ position of benzimidazole antagonized the effects of cisplatin and doxorubicin in MCF-7 cells. Western blotting studies confirmed the potentiation effect of compound 64 and the antagonistic activity of compound 65 , both tested at $0.1 \mu \mathrm{M}$ concentrations. In these experiments, the combination of the former with cisplatin blocked Chk2 phosphorylation in MCF-7 cells, while the combination of the latter with cisplatin did not. The combination of $0.1 \mu \mathrm{M}$ compound 64 with doxorubicin at its $\mathrm{GI}_{50}$ concentration also caused arrest of MCF-7 cells in the S phase of the cell cycle.

\subsubsection{Rapidly Accelerated Fibrosarcoma (RAF) Kinase Inhibitors}

RAF kinases are serine/threonine protein kinases that are activated by the human oncogene RAS. RAF acts in the RAS-RAF-MEK-ERK pathway, which plays a role in cell differentiation, survival, growth, apoptosis, and other cellular processes. ERK ultimately phosphorylates multiple cytoplasmic and nuclear substrates, resulting in the effects mentioned above. The RAF family of kinases consists of ARAF, BRAF, and CRAF, with BRAF mutations commonly occurring in papillary thyroid cancers, melanomas, and hairy cell leukemias. Sorafenib (BAY 43-9006) is a first-generation RAF inhibitor approved by the U.S. FDA for the treatment for renal cancer and hepatocellular carcinoma (HCC). The approval of sorafenib, together with the approval of second-generation RAF inhibitors vemurafenib and dabrafenib which act on cancers harboring BRAF mutations, has sparked interest in the discovery of new molecules selectively targeting this pathway (see References [76,77] for reviews covering RAF signaling and inhibition in cancer). Abdel-Maksoud et al. synthesized a series of imidazothiazole derivatives and studied their BRAF inhibitory activity and cytotoxicity against the NCI 60 cancer cell line panel [78]. These compounds were most active against the colon cancer and melanoma sub-panels. $\mathrm{IC}_{50}$ values for several compounds were determined against the A375 and SKMEL-28 melanoma cell lines, with the most potent compounds 66 and 67 displaying $\mathrm{IC}_{50}$ values of 2.57 and $2.70 \mu \mathrm{M}$ against A375 cancer cells, while compounds 66 and 68 possessed $\mathrm{IC}_{50}$ values of 8.16 and $6.85 \mu \mathrm{M}$ 
against SKMEL-28 cells. In terms of the SAR for these molecules in the melanoma cell lines, among amide-containing compounds, derivatives containing a two carbon linker, such as 66 and 67, showed greater potency compared with agents bearing three carbon linkers. In the case of sulfonamide derivatives, however, compounds with a three carbon linker were generally more potent than those bearing a two carbon linker. The most potent derivatives were tested in the in vitro kinase assay against ${ }^{\mathrm{WT}} \mathrm{BRAF},{ }^{\mathrm{V} 600 \mathrm{E}} \mathrm{BRAF}$, and CRAF, with the compounds displaying $\mathrm{IC}_{50}$ values in the range 9.30-312 nM. These compounds generally showed the highest potency against ${ }^{\mathrm{V} 600 \mathrm{E}} \mathrm{BRAF}$, with compound 69 displaying an $\mathrm{IC}_{50}$ value of $9.30 \mathrm{nM}$.

\subsubsection{Cyclin-Dependent Kinase (CDK) Inhibitors}

The CDKs are an important class of serine/threonine kinases divided into two subfamilies: cell-cycle-related subfamilies (CDK1, 4, and 5) and transcriptional subfamilies (CDK7, 8, 9, 11, and 20; please see Reference [79] for a review of CDKs). Cell-cycle-related subfamilies control various transitional phases of the cell cycle, as well as mitotic progression and transcriptional subfamilies generally control the initiation and elongation of mRNA by the phosphorylation of RNA polymerase II, while some CDKs have a wider range of functions that are often tissue specific. Since cancer cells frequently show dysregulation in cell-cycle or transcriptional CDKs, inhibition of these enzymes may result in a selective antitumor effect (see References [80,81] for further information regarding CDKs in cancer and the use of CDK inhibitors as anticancer drugs).

CDK2 is involved in cell cycle regulation and is considered to be a member of the CDK1 subfamily [79]. Al-Warhi et al. synthesized six imidazole/benzimidazole thioarylethanone derivatives as potential cytotoxic agents against T47D and MCF-7 breast cancer cell lines; these compounds were also tested for CDK2 inhibitory activity [82]. Among these molecules, imidazoles 70 and 71 (see Figure 7 for structures of compounds 70-79) displayed the greatest potency. Compounds 70 and 71 exhibited $\mathrm{IC}_{50}$ values of 8.04 and $11.17 \mu \mathrm{M}$ against T47D cells, respectively, while, against MCF-7 cells, the compounds displayed $\mathrm{IC}_{50}$ values of 12.90 and $4.53 \mu \mathrm{M}$, respectively. In an in vitro CDK2 assay, compound 70 exhibited an $\mathrm{IC}_{50}$ value of 0.89 , while the corresponding $\mathrm{IC}_{50}$ value for compound 71 was $0.62 \mu \mathrm{M}$. Compounds 70 and 71 displayed docking energy scores of -8.7 and $-8.9 \mathrm{kcal} / \mathrm{mol}$ when docked using the crystal structure of CDK2, while lower docking energy scores were obtained when these compounds were docked with crystal structures of CDK4/6, CDK7, and CDK9.

CDK4 and CDK6 promote progression through the $\mathrm{G}_{1}$ cell cycle phase, while CDK1 is critical in mitosis and is the only CDK that is essential for cell cycle progression in mammalian cells [81]. A series of analogs was designed based on the structural features of the approved drug abemaciclib (72), a selective oral CDK4/6 inhibitor indicated for metastatic breast cancer [83]. The synthesized compounds showed high selectivity toward CDK $4 / 6$ compared to CDK1/D3. Compounds 73 and 74 displayed high activity against CDK4/6 with $\mathrm{IC}_{50}$ values of $7.4 / 0.9 \mathrm{nM}$ and $0.6 / 12.7 \mathrm{nM}$, respectively, and low activity against CDK1/D3 ( $\mathrm{IC}_{50}$ values of 2670 and $3072 \mathrm{nM}$, respectively). Of these compounds, only 73 displayed an $\mathrm{IC}_{50}$ value against the MDB-MA-231 cancer cell line (232 nM) comparable to $72(191 \mathrm{nM})$. Compound $\mathbf{7 3}$ was nearly twice as active as $\mathbf{7 2}$ in a hERG channel assay ( $\mathrm{IC}_{50}$ values of 6.38 and $10.9 \mu \mathrm{M}$, respectively) and displayed pharmacokinetic and physicochemical properties similar to those of abemaciclib. Docking studies with 73 indicated binding of this compound to the catalytic domain of CDK6. 


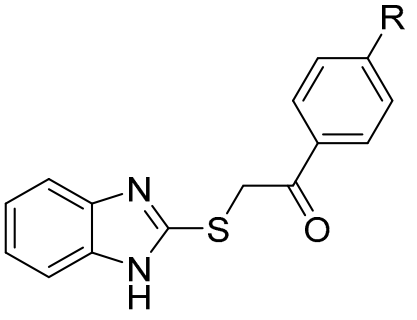

70: $\mathrm{R}=\mathrm{H}$

71: $\mathrm{R}=\mathrm{OMe}$<smiles>CCN1CCN(Cc2ccc(Nc3ncc(F)c(-c4cc(F)c5nc(C)n(C(C)C)c5c4)n3)nc2)CC1</smiles>

abemaciclib (72)<smiles>[R2]N1CCN(Cc2ccc(Nc3ncc(F)c(-c4cc(F)c5nc6n(c5c4)C([R])(C)CC6)n3)nc2)CC1</smiles>

73: $R^{1}=M e, R^{2}=E t$ 74: $\mathrm{R}^{1}=\mathrm{H}, \mathrm{R}^{2}=i-\mathrm{Pr}$<smiles>Nc1ccc(-c2nc3ncccc3[nH]2)cc1</smiles>

75<smiles>O=C1N=NC(=O)C(=CNc2ccc(-c3nc4ncccc4[nH]3)cc2)C(=O)N1</smiles><smiles>[3H]c1ccc(NN=C(C(C)=O)C(C)=O)cc1</smiles><smiles>[R]CCn1cnc2ccc(-c3ccc4nc(NC(=O)CC)[nH]c4c3)cc2c1=O</smiles>

78: $R=$ morpholine

79: $\mathrm{R}=3$-indolyl

Figure 7. Additional imidazole-containing serine-threonine kinase inhibitors targeting CDK and AURK reported in the literature (compounds 70-79).

Ghanem et al. synthesized imidazopyridine derivatives and studied their inhibitory activity against CDK9, as well as their antiproliferative activities, on HCT116 and MCF-7 cell lines [84]. Compounds 75 and 76 were the most potent against the MCF-7 cell line, exhibiting $\mathrm{IC}_{50}$ values of 0.71 and $0.63 \mu \mathrm{M}$, respectively, while compound 77 displayed the greatest activity against the HCT116 cell line $\left(\mathrm{IC}_{50}=1.69 \mu \mathrm{M}\right)$. Compounds 75,76 , and 77 also exhibited $\mathrm{IC}_{50}$ values against $\mathrm{CDK} 9$ of $0.95,0.50$, and $1.00 \mu \mathrm{M}$, respectively, while sorafenib displayed an $\mathrm{IC}_{50}$ value of $0.76 \mu \mathrm{M}$ in this assay. SAR analysis indicated that compounds containing an amine functionality para to the imidazopyridine attachment point generally displayed greater potency against the MCF-7 cell line compared to compounds bearing a diazo group at this position.

\subsubsection{Aurora Kinase (AURK) Inhibitors}

Aurora kinases (A, B and, C) are cell cycle regulated serine-threonine kinases which play roles in different aspects of mitosis; the overexpression of AURKs is associated with wide variety of tumors. The inhibition of AURKs with small molecules, thus, represents an intriguing strategy towards the discovery of novel anticancer agents (see Reference [85] for a review of AURK inhibitors against cancer). Fan et al. synthesized a novel series of benzimidazole-quinazolinones and evaluated these molecules for cytotoxicity against MDA-MB-231, PC-3, and SH-SY5Y cancer cell lines [86]. The most potent molecule in this series, compound 78 , displayed $\mathrm{IC}_{50}$ values of $0.38,1.09$, and $0.77 \mu \mathrm{M}$ against MDA-MB-231, PC-3, and SH-SY5Y cell lines, respectively. Potency was maintained when the morpholine side chain was replaced by an indole side chain, as compound $\mathbf{7 9}$ exhibited $\mathrm{IC}_{50}$ values of 
$0.55,1.67$, and $1.23 \mu \mathrm{M}$, respectively, on the three cell lines. While most of the compounds were active on all three cell lines, attaching the morpholino side chain via an amide linkage rather than a C-N linkage resulted in loss of activity. Both compounds $\mathbf{7 8}$ and $\mathbf{7 9}$ showed selectivity towards AURKA ( $\mathrm{IC}_{50}$ values of 21.9 and $27.1 \mathrm{nM}$, respectively) compared to AURKB ( $\mathrm{IC}_{50}$ values of 273 and $330 \mathrm{nM}$, respectively). Western blotting studies indicated a dose-dependent reduction in AURKA phosphorylation and histone $\mathrm{H} 3$ phosphorylation upon treatment of MDA-MB-231 cells with compound 78 at concentrations ranging from $1.0-4.0 \mu \mathrm{M}$.

\subsubsection{Nek2 Kinase Inhibitors}

Nek2 is a serine/threonine kinase involved in the regulation of several aspects of mitosis that is overexpressed in several cancers, making it an intriguing antineoplastic drug target (anticancer Nek2 inhibitors are reviewed by Fang and Zhang [87]). Wang et al. synthesized imidazopyridine derivatives based on the Nek2 kinase inhibitor MBM-55 (80) (see Figure 8 for structures of compounds 80-87) and evaluated these compounds for activity against the MGC-803 gastric cancer cell line (high expression of Nek2 frequently occurs in gastric cancer cell lines) [88]. Compounds 81, 82, and 83 displayed potent anticancer activity against this cancer cell line, with $\mathrm{IC}_{50}$ values of 44,54 , and $38 \mathrm{nM}$, respectively. Compounds 81-83 were active against the HCT116 cell line ( $\mathrm{IC}_{50}$ values ranging from 0.36-0.48 $\mu \mathrm{M}$, while compound 80 displayed an $\left.\mathrm{IC}_{50}=0.70 \mu \mathrm{M}\right)$, the Hep3B cell line $\left(\mathrm{IC}_{50}\right.$ values ranging from 1.18-1.25 $\mu \mathrm{M}$, while compound 80 exhibited an $\mathrm{IC}_{50}=1.07 \mu \mathrm{M}$ ) and the BEL-7402 cell line $\left(\mathrm{IC}_{50}\right.$ values ranging from 4.33-10.44 $\mu \mathrm{M}$, while compound 80 displayed an $\left.\mathrm{IC}_{50}=6.37 \mu \mathrm{M}\right)$. In general, compounds having amide substitutions on the thiophene ring were more potent compared to their ester analogs. Docking studies indicated that compound $\mathbf{8 3}$ forms an interaction with Nek2 similar to that shown by compound $\mathbf{8 0 .}$

Matheson et al. designed and synthesized novel molecules targeting Nek2 based on a co-crystal structure of compound 84, a non-covalent reversible Nek2 inhibitor, bound to Nek2 [89]. Through examination of this structure, the authors hypothesized that the replacement of the alkoxy group at the purine C6 position of compound 84 with an ethynyl group could result in covalent binding of the ligand to the nearby Cys 22 residue of Nek2. Target compounds 85 and 86 both displayed IC $_{50}$ values of $140 \mathrm{nM}$ against Nek2. Incubation of compound 86 with Nek 2 at $10 \times$ its $\mathrm{IC}_{50}$ concentration followed by rapid dilution of the Nek2 sample resulted in 3\% recovery of activity compared to $11 \%$ recovery of activity after treatment of Nek2 with control competitive inhibitors, providing evidence for the irreversible inhibition of Nek2 by compound 86. Compound 85 displayed weak competitive inhibition of Nek2-C22A (in which the Cys22 residue of Nek2 was mutated to Ala) with an $\mathrm{IC}_{50}$ value of $3.5 \mu \mathrm{M}$. When compounds 85 and 86 were tested against a panel of Ser-Thr kinases, they typically displayed $>10$-fold selectivity for Nek2 over other kinases, although this was not the case for the inhibition of Cdk2 by compound $86\left(\mathrm{IC}_{50}=0.84 \mu \mathrm{M}\right)$. Target compound 85 displayed $\mathrm{GI}_{50}$ values of $1.8,1.2,1.1$, and $0.2 \mu \mathrm{M}$ against U2OS, HeLa, MDA-MB-231, and HEK-293 cell lines, respectively, while compound 86 was inactive against U2OS and HeLa cells (presumably due to a lack of cell penetration). The synthesis of analogs based on 85 provided compounds generally displaying midnanomolar $\mathrm{IC}_{50}$ values against Nek2, but a poor correlation was observed between Nek2 activity and cellular GI $_{50}$ values against the SK-BR-3 cell line. Nonetheless, compound $87\left(\mathrm{Nek} 2 \mathrm{IC}_{50}=0.062 \mu \mathrm{M}\right.$, cellular SK-BR-3 $\left.\mathrm{GI}_{50}=2.2 \mu \mathrm{M}\right)$ displayed selectivity for Nek2 when this compound was profiled against a panel of 121 kinases, and compounds 85 and 87 inhibited the phosphorylation of C-Nap1, a specific substrate of Nek2, in U2OS cells. X-ray co-crystal structures of $\mathbf{8 6}$ and $\mathbf{8 7}$ complexed with Nek2 confirmed that the ethynyl group of these ligands both formed a covalent bond with Cys22 of Nek2. 

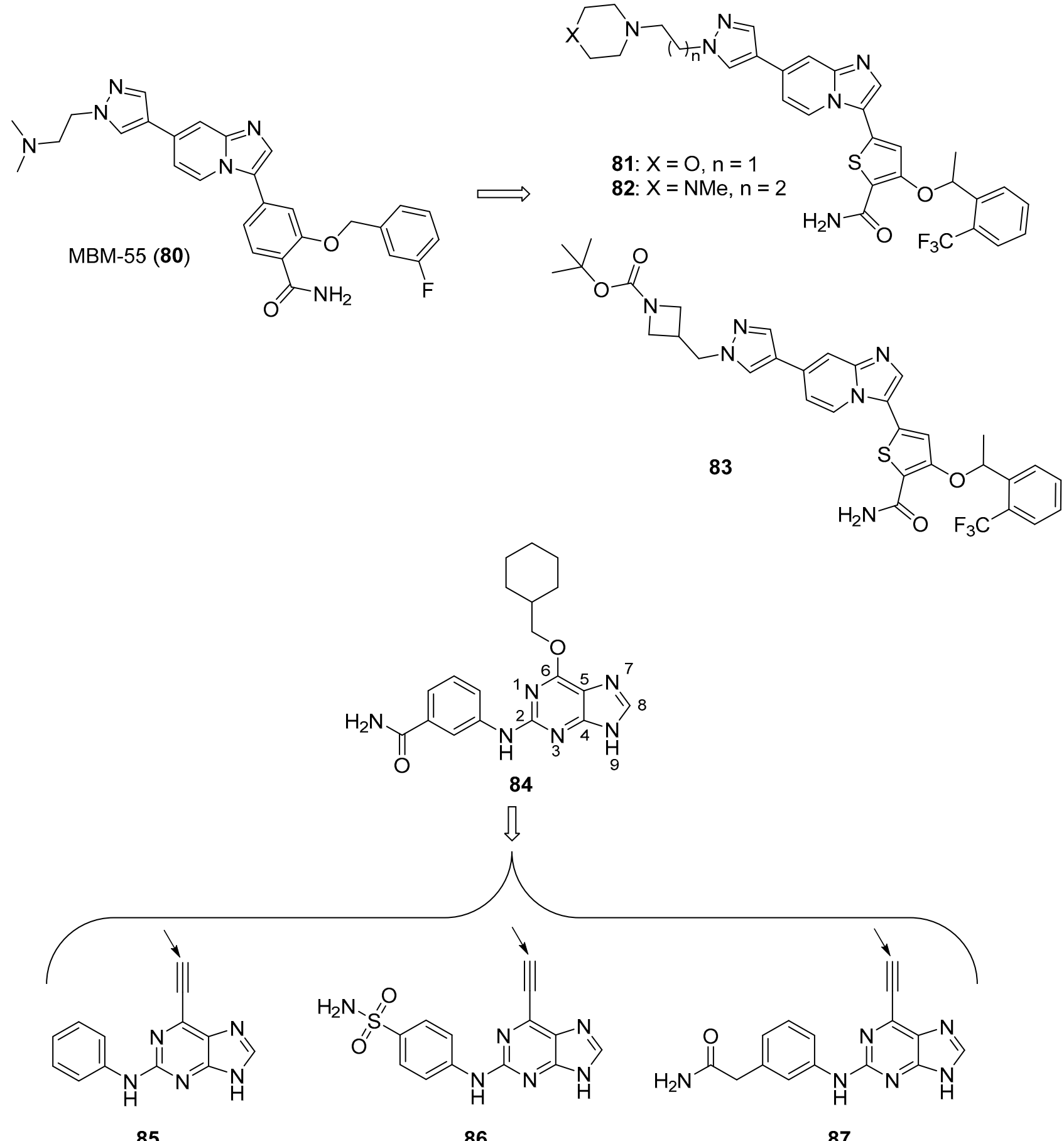

Figure 8. Imidazole-containing Nek2 kinase inhibitors reported in the literature (compounds 80-87). For compounds 85-87, the proposed sites for covalent inhibition of Nek2 kinase are indicated by the solid arrows.

\subsection{Phosphatidylinositol-3-Kinase (PI3K)/AKT/mTOR Inhibitors}

Signaling through the PI3K/AKT/mTOR pathway is initiated by receptor tyrosine kinases and G-protein coupled receptors (GPCRs) present on the cell surface. Kinase interactions downstream of PI3K are known to involve a complex signaling cascade which influences cell proliferation, cell cycle progression, cell growth, and cell survival. Dysregulation of the PI3K/AKT/mTOR signaling pathway has been found in most cancers, such as breast, lung, blood, ovarian, and colorectal malignancies, indicating that this pathway is worthy of exploration in a wide range of cancers (please see References $[77,90]$ for reviews of 
PI3K signaling and inhibition). The PI3K inhibitors idelalisib and copanlisib are approved for the treatment of leukemia and lymphoma [91], while the PI3K $\alpha$ inhibitor alpelisib has been approved in combination with fulvestrant for the treatment of certain types of breast cancer [92]. These successes, together with the desire to improve side effect profiles, have driven continued research on compounds that affect the PI3K/AKT/mTOR pathway.

Ding et al. synthesized a novel series of disubstituted benzimidazoles based on fragment features taken from GSK2292767 (88) and the previously reported PI3K inhibitor HS-173 (89) (structures for compounds 88-103 are provided in Figure 9) possessing potent anticancer activity towards the T47D, MCF-7, and HCT116 cell lines [93]. Most of the synthesized compounds were active against these cell lines, possessing $\mathrm{IC}_{50}$ values below $5.0 \mu \mathrm{M}$. Compounds 90 ( $\mathrm{IC}_{50}$ values of $0.27,0.57$, and $\left.0.13 \mu \mathrm{M}\right), 91$ ( $\mathrm{IC}_{50}$ values of 0.36 , 0.31 , and $0.14 \mu \mathrm{M}), 92$ ( $\mathrm{IC}_{50}$ values of $0.45,0.59$, and $\left.0.85 \mu \mathrm{M}\right)$, and 93 ( $\mathrm{IC}_{50}$ values of 0.29 , 0.41 and $0.34 \mu \mathrm{M}$ ) were among the most potent compounds against the three cell lines, respectively. Compounds 91 and 92 showed improved activity against $\mathrm{PI} 3 \mathrm{~K} \alpha, \mathrm{PI} 3 \mathrm{~K} \beta$, $\mathrm{PI} 3 \mathrm{~K} \gamma$, and $\mathrm{PI} 3 \mathrm{~K} \delta$ when compared to 89, with $\mathrm{IC}_{50}$ values ranging from $0.50-5.5 \mathrm{nM}$. Western blotting analysis indicated that compound $\mathbf{9 1}$ inhibited AKT phosphorylation when incubated with HCT116 cells at a $3 \mu \mathrm{M}$ concentration.

Xiao et al. synthesized imidazoquinoline derivatives and screened them for antitumor activity against PC-3, HepG2, A549, and MCF-7 cell lines [94]. Compounds 95 and 96 displayed activity against HepG2, A549, and PC-3 cell lines with $\mathrm{IC}_{50}$ values of 1.43, 13.43, $6.67 \mu \mathrm{M}$ and 2.42, 6.29, 5.11 $\mu \mathrm{M}$, respectively. The dual PI3K-mTOR inhibitor NVP-BEZ235 (94) displayed $\mathrm{IC}_{50}$ values of $0.54,0.36$, and $0.20 \mu \mathrm{M}$ against HepG2, A549, and PC-3 cell lines, respectively. Compounds 95 and 96 inhibited PI3K $\alpha\left(\mathrm{IC}_{50}: 6.8,0.9 \mu \mathrm{M}\right)$ and $\mathrm{mTOR}$ kinases $\left(\mathrm{IC}_{50}: 4.6,1.4 \mu \mathrm{M}\right)$. Since the $\mathrm{IC}_{50}$ values of 94 against $\mathrm{PI} 3 \mathrm{~K} \alpha$ and $\mathrm{mTOR}$ kinases were 4 and $6 \mathrm{nM}$, respectively, compounds 95 and 96 may display anticancer activity through other mechanisms. SAR studies showed that the placement of bromine at the C6 position of quinoline is essential for activity.

$\mathrm{Wu}$ et al. synthesized a novel series of molecules possessing a triazine-benzimidazole scaffold based on the PI3K inhibitor gedatolisib (97) designed to act as potential anticancer agents through the inhibition of PI3K/mTOR [95]. All but one of the target compounds inhibited PI3K and mTOR with $\mathrm{IC}_{50}$ values below $200 \mathrm{nM}$. Compounds 98 and 99 were among the most potent target compounds and were more active towards PI3K $\delta$ compared to other PI3K isoforms, with $\mathrm{IC}_{50}$ values of 5.1 and $13.0 \mathrm{nM}$, respectively, compared to 97 $\left(\mathrm{IC}_{50}=156 \mathrm{nM}\right)$. Compounds 98 and 99 displayed $\mathrm{IC}_{50}$ values of 0.9 and $0.3 \mu \mathrm{M}$ against the HCT116 cell line, while 97 displayed an $\mathrm{IC}_{50}$ value of $1.4 \mu \mathrm{M}$. Western blotting studies in this cell line showed that $10 \mu \mathrm{M}$ concentrations of compounds $\mathbf{9 8}$ and 99 almost completely inhibited the phosphorylation of AKT and p70S6K, the latter protein being downstream of the PI3K/AKT/mTOR signaling pathway.

A series of arylthio- and arylamino-benzimidazole derivatives of dehydroabietic acid (100) synthesized by Yang et al. were tested for PI3K inhibition, as well as activity against HCT116, MCF-7, HeLa, and HepG2 cancer cell lines [96]. Counter-screening was also performed against a normal human gastric mucosal cell line (GES-1). Among these compounds, 101 displayed the highest potency, with $\mathrm{IC}_{50}$ values of $0.18,0.43,0.71$, and $0.63 \mu \mathrm{M}$ against these four cancer cell lines, respectively. Compound 101 also displayed lower cytotoxicity against the GES-1 cell line, with an $\mathrm{IC}_{50}$ value of $22.0 \mu \mathrm{M}$. In general, compounds having 2-arylthio substitutions at the benzimidazole $\mathrm{C} 2$ position were less potent compared to 2-arylamino derivatives. Moreover, compounds substituted with electron-withdrawing substituents at the para position of the arylamino or arylthio rings displayed stronger activities. Compound 101 displayed $\mathrm{IC}_{50}$ values of $0.012,0.21,0.18$, and 0.11 against $\mathrm{PI} 3 \mathrm{~K} \alpha, \beta, \gamma$, and $\delta$, respectively, while it was inactive against mTOR $\left(\mathrm{IC}_{50}>10 \mu \mathrm{M}\right)$. Western blotting studies with compound 101 in HCT116 cells showed that 101 inhibited AKT phosphorylation in a dose-dependent manner at concentrations of 0.5 and $1.0 \mu \mathrm{M}$. 
<smiles>COc1ncc(-c2ccc3[nH]ncc3c2-c2ncc(CN3CC(C)OC(C)C3)o2)cc1NS(C)(=O)=O</smiles>

GSK2292767 (88)<smiles>CCOC(=O)c1cnc2ccc(-c3cncc(NS(=O)(=O)c4ccccc4)c3)cn12</smiles>

N<smiles>Cn1c(=O)n(-c2ccc(C(C)(C)C#N)cc2)c2c3cc(-c4cnc5ccccc5c4)ccc3ncc21</smiles>

NVP-BEZ235 (94)<smiles>CN(C)C1CCN(C(=O)c2ccc(NC(=O)Nc3ccc(-c4nc(N5CCOCC5)nc(N5CCOCC5)n4)cc3)cc2)CC1</smiles>

gedatolisib (97)<smiles>C=CCc1cc(C(C)C)ccc1C1(C)CCC[C@](C)(C(=O)O)[C@@H]1C</smiles>

dehydroabietic acid (100)<smiles>COC(=O)[C@]1(C)CCC[C@]2(C)c3cc(Br)c4nc(Nc5ccc(C#N)cc5)[nH]c4c3CCC21</smiles><smiles>[R]Oc1ccc(-n2cnc3ccc(-c4cnc(OC)c(NS(=O)(=O)c5ccc(F)cc5F)c4)cc32)cc1</smiles><smiles>[R]c1nc2cnc3ccc(Br)cc3c2n1-c1ccc(C(C)(C)C#N)cc1</smiles>

95: $\mathrm{R}=\mathrm{Me}$

96: $\mathrm{R}=\mathrm{H}$<smiles>[R]C(=O)c1ccc2nc(Nc3ccc(-c4nc(N5CCOCC5)nc(N5CCOCC5)n4)cc3)[nH]c2c1</smiles>

98: $\mathrm{R}=(R)$-pyrrolidine-2-carboxamide

99: $\mathrm{R}=$ morpholine<smiles></smiles>

Figure 9. Proposed imidazole-containing PI3K/AKT/mTOR inhibitors reported in the literature (compounds 88-103). 
Zuo et al. synthesized piperazinone-purine hybrids as selective PI3K $\delta$ inhibitors targeting non-Hodgkin's lymphomas [97]. WNY1613 (102) displayed an $\mathrm{IC}_{50}$ value of $1.2 \mathrm{nM}$ against PI3K $\delta$ and selectivity indexes $\left(\mathrm{IC}_{50} \mathrm{vs}\right.$. the kinase of interest $/ \mathrm{IC}_{50} \mathrm{vs}$. PI3K $\delta$ ) of 219, 120, and 250 relative to PI3K $\alpha$, PI3K $\beta$, and PI3K $\gamma$, respectively. Moreover, this compound only displayed activity $>50 \%$ against PI3K isoforms when tested at a concentration of $500 \mathrm{nM}$ against a panel of 300 other kinases. Compound 102 displayed antiproliferative activity against the SU-DHL-4 and SU-DHL-6 (B-cell lymphoma) cell lines ( $\mathrm{IC}_{50}$ values of 0.048 and $0.038 \mathrm{nM}$ ), and also exhibited an $\mathrm{IC}_{50}$ value of $0.077 \mu \mathrm{M}$ against the JEKO-1 mantle cell lymphoma line. The reference drug idelalisib displayed $\mathrm{IC}_{50}$ values of $0.30,0.12$, and $0.12 \mu \mathrm{M}$ against these cell lines, respectively. Western blotting analysis with compound 102 in SU-DHL-4, SU-DHL-6, and JEKO-1 cell lines revealed a dose and time dependent inhibition of phosphorylation of S6, AKT, and 4EBP1, all downstream components of PI3K signaling. In xenograft models employing JEKO-1 and SU-DHL-6 cells in non-obese diabetic SCID mice, idelalisib and compound 102 administered orally at $25 \mathrm{mg} / \mathrm{kg}$ for 18 days displayed tumor growth inhibition of $45.9 \%$ and $55.5 \%$ for the JEKO-1 model and $47.7 \%$ and $51.4 \%$ for the SU-DHL- 6 model compared to the control groups, respectively. Increasing the dose of compound 102 to $50 \mathrm{mg} / \mathrm{kg}$ did not result in a significant improvement of its antitumor effect.

Gaonkar et al. synthesized substituted pyrimidine derivatives as antiproliferative agents that were evaluated against HeLa, MCF-7, HepG2, NCI-H460, and IMR-32 cancer cell lines [98]. Target compound $\mathbf{1 0 3}$ contained imidazole at the $\mathrm{C} 2$ position of the pyrimidine core and displayed the greatest potency against HeLa cells $\left(\mathrm{IC}_{50}=5.88 \mu \mathrm{M}\right)$. Treatment of HeLa cells with compound 103 at 5, 10, and $20 \mu \mathrm{M}$ concentrations resulted in the dose-dependent accumulation of cells in the sub- $\mathrm{G}_{1}$ phase of cell cycle and the induction of apoptotic cell death. Since morpholinopyrimidines, such as apitolisib (GDC0980), have shown activity as PI3K/mTOR inhibitors [99], molecular docking studies were performed between compound $\mathbf{1 0 3}$ and mTOR's catalytic domain. The authors reported several interactions between compound $\mathbf{1 0 3}$ and amino acids at the ATP binding pocket of mTOR.

\section{Imidazoles as Inhibitors of Other Targets}

\subsection{DNA Intercalators}

Intercalators are classes of small molecules that insert between adjacent DNA base pairs, causing significant deformation of the double helix. These compounds typically contain planar polyaromatic regions which stack with DNA bases, but intercalators may also make ionic and hydrogen bonding interactions with DNA. Due to these alterations in DNA, intercalators may interfere with replication, transcription, cell growth, and cell division. Interest in DNA intercalators as potential anticancer agents remains robust (see References $[100,101]$ for reviews of DNA intercalating agents), and a better understanding of the interactions between DNA and anticancer candidates may help medicinal chemists to design intercalating molecules with improved anticancer activity.

Zhao et al. synthesized Schiff base derivatives of dehydroabietylamine (104) (see Figure 10 for structures of compounds 104-114) as potential anticancer agents and evaluated these compounds for activity against MCF-7, A549, HeLa, and HepG2 cancer cell lines, with HUVECs used as a normal reference cell line [102]. Most of the derivatives displayed $\mathrm{IC}_{50}$ values ranging from 2.5-15 $\mu \mathrm{M}$ against MCF-7 cells, while compounds 105 and 106 exhibited the highest potency against HepG2 cells ( $\mathrm{IC}_{50}$ values of 0.24 and $0.14 \mu \mathrm{M}$, respectively). By comparison, 104 displayed an $\mathrm{IC}_{50}$ value of $2.56 \mu \mathrm{M}$ against HepG2 cells. Interestingly, 106 was 180 times more potent against HepG2 cells compared to HUVECs. Addition of compounds $\mathbf{1 0 5}$ and $\mathbf{1 0 6}$ to salmon sperm DNA complexed with ethidium bromide resulted in a reduction in fluorescence, consistent with binding of compounds $\mathbf{1 0 5}$ and 106 to DNA. A hypochromic shift was observed upon adding more DNA to solutions containing compounds 105 and 106, consistent with the hypothesis that these compounds bind to DNA via intercalation. 
<smiles>CC(C)c1ccc2c(c1)CCC1C(C)(CN)CCCC21C</smiles>

dehydroabietylamine (104)<smiles>CC(C)c1ccc2c(c1)CCC1C(C)(CN=Cc3ncc[nH]3)CCCC21C</smiles><smiles>CC(C)c1ccc2c(c1)CCC1C(C)(CN=Cc3c[nH]cn3)CCCC21C</smiles><smiles>CC(C)c1ccc2c(c1)CCC1C(C)(C[NH3+])CCCC21C</smiles>

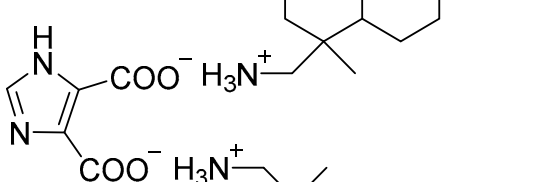

108<smiles>CC(C)c1ccc2c(c1)CCC1C(C)(C)CCCC21C</smiles><smiles></smiles>

109<smiles>c1ccc(Cn2cnc3ccc(-c4nc(-c5ccc6c(c5)ncn6C5CCCCC5)cn5ccnc45)cc32)cc1</smiles><smiles>c1cn2cc(-c3ccc4ncn(C5CCCCC5)c4c3)nc(-c3ccc4c(c3)ncn4C3CCCCC3)c2n1</smiles><smiles>CN(C)CCN1C(=O)c2cccc3c(-c4ccc5ncn(C6CCCCC6)c5c4)ccc(c23)C1=O</smiles>

110<smiles>COc1ccc(-c2cn3ccnc3c(-c3ccc4ncn(C5CCCCC5)c4c3)n2)cc1</smiles><smiles>O=C1NC(=O)/C(=C/c2ccc(-c3nc4c5ccccc5c5ccccc5c4[nH]3)cc2)S1</smiles>

Figure 10. Imidazole-containing compounds reported as DNA intercalators (compounds 104-114).

Further extension of the work by Zhao et al. conveyed the synthesis of imidazole derivatives of compound 104 (organic salts and amides) [103]. All the compounds derived from 104 were more potent against MCF-7 cancer cells compared to the parent compound. Among these, compounds 107 and 108 displayed $\mathrm{IC}_{50}$ values of 6.47 and $0.75 \mu \mathrm{M}$ against MCF-7 cells compared to compound $104\left(\mathrm{IC}_{50}=19.45 \mu \mathrm{M}\right)$. Compound 107 displayed greater potency against $\mathrm{A} 549$ cells $\left(\mathrm{IC}_{50}=1.85 \mu \mathrm{M}\right)$ compared to compound $104\left(\mathrm{IC}_{50}=5.02 \mu \mathrm{M}\right)$. As above, spectroscopic experiments were used to provide evidence for the binding of these compounds to DNA via intercalation.

A series of compounds reported by Singh et al. explored the benzimidazole scaffold for the synthesis of DNA-interactive anticancer candidates [104-107]. In one such effort, naphthalimide-benzimidazole hybrid compounds were prepared as potential antiprolif- 
erative agents against the NCI panel of 60 human cancer cell lines [104]. Based on the evaluation of 18 target compounds against this panel at a single $10 \mu \mathrm{M}$ dose, compounds $\mathbf{1 0 9}$ and $\mathbf{1 1 0}$ were chosen for testing against the full panel of cell lines at concentrations ranging from 0.01 to $100 \mu \mathrm{M}$. Mean graph midpoint $\left(\mathrm{GI}_{50}\right)$ values of 1.43 and $1.83 \mu \mathrm{M}$ were determined for compounds 109 and 110, respectively, with $\mathrm{GI}_{50}$ values ranging from $0.372-2.23 \mu \mathrm{M}$ for compound 109 and $0.422-3.95 \mu \mathrm{M}$ for compound 110 against the sixty cell line panel. Compounds $\mathbf{1 0 9}$ and $\mathbf{1 1 0}$ increased the melting temperature of calf thymus DNA by 14.2 and $5.9^{\circ} \mathrm{C}$, respectively, while circular dichroism studies indicated that these compounds bound to calf thymus DNA via intercalation.

Benzimidazole-imidazopyrazine conjugates were synthesized and were also evaluated for their antiproliferative activity on the NCI 60 panel of cancer cell lines [105]. Compound 111 showed $\mathrm{GI}_{50}$ values ranging between $312-890 \mathrm{nM}$ against K562 and SR leukemia, NCIH460 and NCI-H522 non-small cell lung cancer, HCT116 and HT29 colon cancer, SF-295 CNS cancer, and MDA-MB-435 melanoma cancer cell lines. Compound 112 displayed a $\mathrm{GI}_{50}$ value of $799 \mathrm{nM}$ against the 786-0 renal cancer cell line. Spectroscopic studies indicated the binding of compounds $\mathbf{1 1 1}$ and $\mathbf{1 1 2}$ to calf thymus DNA. In thermal denaturation studies, compounds 111 and 112 displayed $\Delta T m$ values of $22^{\circ} \mathrm{C}$ and $12{ }^{\circ} \mathrm{C}$, respectively, in the presence of calf thymus DNA, indicating that compound 109 has a strong affinity for DNA. Exposure to increasing concentrations of compounds 111 and 112 caused a dosedependent decrease in the fluorescence intensity of the ethidium bromide-DNA complex, indicating displacement of ethidium bromide from DNA by these compounds. Circular dichroism studies with compounds $\mathbf{1 1 1}$ and $\mathbf{1 1 2}$ in the presence of calf thymus DNA suggested an intercalative mode of DNA binding for these molecules. In an extension of the work described above, compound $\mathbf{1 1 3}$ displayed broad spectrum activity with $\mathrm{GI}_{50}$ values in the range between $0.80-2.87 \mu \mathrm{M}$ against 59 human cancer cell lines [106]. This compound increased the melting temperature of calf thymus DNA by $12^{\circ} \mathrm{C}$. A binding constant $\left(\mathrm{K}_{\mathrm{b}}\right)$ of $1.25 \times 10^{4} \mathrm{M}^{-1}$ was determined for the interaction of compound 113 with calf thymus DNA, and spectroscopic studies indicated that this compound bound to DNA via intercalation. Compound $\mathbf{1 1 3}$ displayed effective binding with bovine serum albumin (BSA) $\left(\mathrm{K}_{\mathrm{b}}=3.79 \times 10^{4} \mathrm{M}^{-1}\right)$, indicating that albumin may be capable of transporting this molecule in the blood.

Singh et al. also synthesized a novel series of phenanthrene/acenaphthalene-fused imidazole derivatives which were screened for in vitro antitumor activity against the NCI 60 cancer cell line panel [107]. At a concentration of $10 \mu \mathrm{M}$, compound 114 displayed $>50 \%$ inhibition against leukemia (HL-60, K562, CCRF-CEM, RPMI8226, and SR), colon (HCT116 and HCT-15), melanoma (MDA-MB-435), renal (A498), prostate (PC-3), and breast (BT-549 and MDA-MB-468) cancer cell lines. Compound 114 exhibited an $\mathrm{IC}_{50}$ value of $1.70 \mu \mathrm{M}$ against A549 cells but showed little effect on the HEK-293 cell line at a concentration of $100 \mu \mathrm{M}$. Spectroscopic studies showed that compound 114 bound to DNA via intercalation. The binding constant $\left(\mathrm{K}_{\mathrm{b}}\right)$ between compound 114 and BSA was $6.57 \times 10^{4} \mathrm{M}^{-1}$, while the corresponding $\mathrm{K}_{\mathrm{b}}$ for the human serum albumin-compound $\mathbf{1 1 4}$ complex was $9.35 \times 10^{4} \mathrm{M}^{-1}$.

\subsection{G-Quadruplex Stabilizers}

G-quadruplexes (G4s) are four-stranded guanine-rich sequences present in the telomere and promotor regions of the human genome that play important roles regulating replication, transcription, and translation. The level of G4s is elevated in tumors and G4s frequently occur in proto-oncogenes; stabilization of these sequences by G4 ligands may block replication, transcription, and translation that is vital to cancer cells (see Reference [108] for a review of G-quadruplexes in cancer). For example, the c-MYC protein, which is dysregulated in several cancers, is coded by a gene that contains a G-rich promoter element that forms G4s [109]. Stabilization of $c-M Y C$ G4s with a small molecule has been shown to be promising anticancer strategy [110]. The design of ligands that bind to 
G-quadruplexes and regulate various genetic functions through stabilization of G4s has, thus, become an interesting focus area for anticancer drug discovery.

Phenanthroimidazole derivatives were synthesized by Wu et al. as potential anticancer agents targeting $c-M Y C$ G-quadruplexes [111]. Compound 115 (see Figure 11 for structures of compounds 115-130) displayed an $\mathrm{IC}_{50}$ value of $1.1 \mu \mathrm{M}$ against the CNE- 1 cell line, while compound 116 exhibited an $\mathrm{IC}_{50}$ value of $0.9 \mu \mathrm{M}$ against the MCF-7 breast cancer cell line. Binding of compounds 115, 116, and 117 to $c-M Y C$ G4 DNA was demonstrated by hypochromic shifts observed upon addition of this DNA to these compounds at a concentration of $20 \mu \mathrm{M}$. Western blotting experiments showed that treatment of CNE-1 cells with compound 115 at concentrations of $0.5-2.0 \mu \mathrm{M}$ resulted in decreased expression of the c-MYC protein in a dose-dependent manner. When given at doses of 3 and $6 \mu \mathrm{M}$, compound 115 inhibited the migration and proliferation of CNE-1 cells in a zebrafish xenograft model of nasopharyngeal carcinoma.<smiles>[R]c1cc(-c2nc3c4cccnc4c4ncccc4c3[nH]2)c([R])c([R])c1[R]</smiles>

115: $R^{1}=R^{2}=C l, R^{3}=R^{4}=H$ 116: $R^{1}=R^{2}=H, R^{3}=R^{4}=C l$ 117: $R^{1}=R^{3}=C l, R^{2}=R^{4}=H$<smiles>[R]Cn1cnc2c1ncn1c(NC(C)(C)C)c(-c3ccc([R])cc3[R])nc21</smiles>

118: $R^{1}=N(M e)_{2}, R^{2}=H, R^{3}=$ morpholino, $n=2$ 119: $\mathrm{R}^{1}=\mathrm{Cl}, \mathrm{R}^{2}=\mathrm{H}, \mathrm{R}^{3}=\mathrm{N}(\mathrm{Me})_{2}, \mathrm{n}=3$

120: $R^{1}=H, R^{2}=F, R^{3}=N(M e)_{2}, n=3$<smiles>CN1CCN(c2ccc(-c3nc(-c4ccc(-c5nc(-c6ccc(N7CCN(C)CC7)cc6)c(-c6ccc(F)cc6)[nH]5)cc4)[nH]c3-c3ccc(F)cc3)cc2)CC1</smiles><smiles>[R]c1ccc(-c2ccc3ncc(-c4nnc(C)o4)c(OCCCn4ccnc4)c3c2)cc1[R]</smiles>

122: $R^{1}=M e, R^{2}=H$

123: $R^{1}=O M e, R^{2}=H$

124: $R^{1}=H, R^{2}=O M e$<smiles>[R]CCCNC(=O)c1c(C)oc2c1C(=O)c1ccc([R])cc1C2=O</smiles>

AS4583 (125): $R^{1}=H, R^{2}=$ imidazole 126: $R^{1}=H, R^{2}=$ pyrrolidine

RJ-LC-07-48 (127): $R^{1}=F, R^{2}=$ imidazole

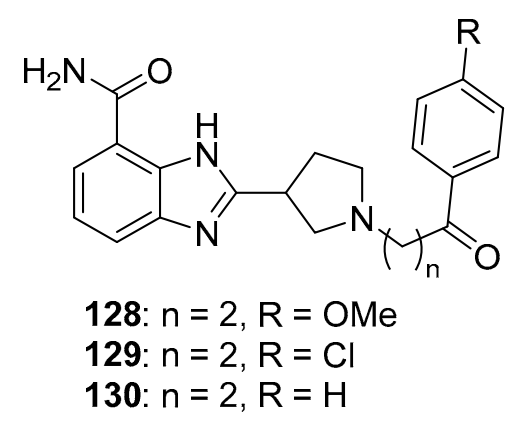

Figure 11. Imidazole-containing compounds and their derivatives targeting G4s, TPI, MCMs, and PARP (compounds 115-130). For the scaffold represented by compounds 122-124, the arrow indicates the position where loss of activity was observed upon modification. 
Pelliccia et al. synthesized imidazopurine derivatives as potential G4-targeting anticancer agents [112]. The authors initially synthesized compound 118, which displayed a significant effect on the melting temperature $(\Delta T m)$ of $G 4$ forming DNA sequences from oncogene promotors ( $\triangle T m$ for BCL2 G4, c-MYC G4, and $c-K I T 1 \mathrm{G} 4$ of $9.2,7.2$, and $5.2{ }^{\circ} \mathrm{C}$, respectively), while increasing the $\Delta T m$ of telomeric G4 Tel23 by only $2.4{ }^{\circ} \mathrm{C}$. Moreover, compounds 119 and 120 were synthesized as part of a focused library of analogs of 118; these compounds showed selectivity for increasing the melting temperature of $B C L 2$ and c-MYC G4 regions over telomeric G4 Tel23 and duplex DNA. Compound 119 displayed an $\mathrm{IC}_{50}$ value of $17 \mu \mathrm{M}$ against the Jurkat cell line but showed little effect on the growth of MCF-7, HCT116, or A375 cancer cell lines or against nonmalignant human dermal fibroblasts (HDF) or human keratinocytes (HaCaT). Compound 120 decreased the survival of Jurkat cells by approximately $60 \%$ at a concentration of $50 \mu \mathrm{M}$. Reduction of $c-M Y C$ expression by $66 \%$ and $56 \%$ was observed by qPCR when Jurkat cells were exposed to $25 \mu \mathrm{M}$ concentrations of compounds 119 and 120, respectively. Similarly, treatment with compounds 119 and 120 caused $67 \%$ and $43 \%$ inhibition of BCL2 expression in Jurkat cells. Western blotting analysis revealed that exposure of Jurkat cells to compound 119 at a concentration of $25 \mu \mathrm{M}$ reduced c-MYC and BCL-2 protein levels by approximately $50 \%$ and $40 \%$, respectively, with compound $\mathbf{1 2 0}$ having less effect on the expression of these proteins.

In a subset of cancers, a telomerase-independent mechanism (alternative lengthening of telomeres or the ALT pathway) maintains telomeres (reviewed in Reference [113]). Hu et al. synthesized dimeric arylimidazole derivatives designed to target telomeric G4s, which are multimeric, and inhibit the ALT pathway [114]. Among these target molecules, compound 121 displayed high selectivity towards a multimeric $\mathrm{G} 4$ sequence (tel45) over a monomeric G4 sequence (tel21). Compound 121 displayed $\Delta T_{m}$ values of $12.7^{\circ} \mathrm{C}$ and $1.7^{\circ} \mathrm{C}$ for tel45 and tel21, respectively, in line with the smaller dissociation constant determined for the DIZ-3/tel45 complex $(4.6 \mu \mathrm{M})$ compared to the DIZ-3/tel21 complex $(18.4 \mu \mathrm{M})$. The results of titration experiments with 121 together with tel45 substituted with the fluorescent base analog 2-aminopurine were consistent with $\mathbf{1 2 1}$ binding to tel45 via intercalation. 121 displayed an $\mathrm{IC}_{50}$ value of $2.1 \mu \mathrm{M}$ against U2OS cells, an ALT cancer cell line, while 121 exhibited an $\mathrm{IC}_{50}$ value of $29.3 \mu \mathrm{M}$ against normal BJ fibroblasts. This compound did not inhibit the transcription of the G4-driven oncogenes $c-M Y C, H R A S, V E G F, B C L-2$, and c-KIT in U2OS cells, indicating its selectivity for multimeric G4s.

\subsection{Topoisomerase Inhibitors}

DNA topoisomerases play important roles in modifying DNA topology, with type 1 topoisomerases (TopI, which make single strand cuts in DNA) and type II topoisomerases (TopII, which result in DNA double strand cleavage) both serving as targets for clinical anticancer drugs. Anticancer agents, such as doxorubicin, etoposide, and topotecan, promote topoisomerase-mediated DNA cleavage, while inhibitors of catalytic function have not enjoyed significant clinical success (see Reference [115] for a review of topoisomerases in cancer). Despite the clinical efficacy of these topoisomerase-targeted agents, their shortcomings, such as dose-limiting toxicities, drug resistance, and poor solubility, limit their use, leading to the exploration of additional compounds designed to target DNA topoisomerases (see Reference [116] for a recent review of anticancer topoisomerase inhibitors). Kundu et al. tested the activity of novel quinoline-based compounds bearing an imidazole side chain in vitro against recombinant TopI and on TopI activity in MCF-7 cellular lysates [117]. Compounds 122, 123, and 124 displayed $\mathrm{IC}_{50}$ values against recombinant TopI of 1.06, 0.029 , and $1.054 \mu \mathrm{M}$, respectively, and $\mathrm{IC}_{50}$ values against this activity in MCF-7 lysates of 3.75, 2.74, and $4.11 \mu \mathrm{M}$, respectively. SAR results show that substitution at the oxadiazole position indicated by an arrow with hydrophilic and hydrophobic groups, such as amino or methyl, caused a drastic loss of activity. Compound $\mathbf{1 2 3}$ stabilized TopI-mediated cleavable complex in MCF-7 cells at a concentration of $5 \mu \mathrm{M}$, and treatment of MCF-7 cells with this compound also resulted in the formation of less reversible TopI- 
induced DNA strand breaks compared to the known TopI modulator camptothecin. Results from DNA unwinding assays and ethidium bromide (EtBr) displacement assays suggested that compound $\mathbf{1 2 3}$ was not a DNA intercalator. Further, compound $\mathbf{1 2 3}$ displayed $\mathrm{IC}_{50}$ values of 2.74, 2.61, 2.34, and $2.35 \mu \mathrm{M}$ against MCF-7, HeLa, HCT116, and NIH:OVCAR-3 cancer cell lines and an $\mathrm{IC}_{50}$ value of $8.34 \mu \mathrm{M}$ against the HEK-293 kidney cell line.

\subsection{Inhibitors of Minichromosomal Maintenance Proteins (MCMs)}

MCMs display helicase activity and play important roles in DNA replication and cell cycle progression (a review of these proteins is given in Yu et al. [118]), and overexpression of MCMs has been linked to poor outcomes in cancer [119]. The search to find novel molecules which target MCMs is, therefore, an emerging area in anticancer drug discovery. High-throughput screening of a library containing two million molecules performed by Lin et al. identified the furanonaphthoquinone-based molecule AS4583 (125) that acted as a potent antiproliferative agent in tyrosine kinase inhibitor (TKI)-sensitive and TKI-resistant NSCLC cells $\left(\mathrm{IC}_{50}=77 \mathrm{nM}\right)$ by targeting the MCM complex [120]. Treatment of athymic nude mice bearing H1975 tumors with compound 125 for 5 days a week over 4 weeks resulted in reduced tumor volumes compared to the control group (44\% and $59 \%$ reduction compared to control at 1 and $4 \mathrm{mg} / \mathrm{kg}$, respectively). Compound 125 interfered with DNA replication by inhibiting the formation of replication forks in H1975 cells as determined by immunofluorescence staining of MCM2. Moreover, this compound promoted the dosedepended degradation of MCM2, MCM6, and MCM7 in H1975, H3255, and PC9 lung cancer cell lines at concentrations of 100 and $200 \mathrm{nM}$. In terms of the SAR, the benzoquinone moiety and the furan oxygen atom were essential for activity. Substitution of imidazole with pyrrole or a phenyl group decreased the antiproliferative activity. Replacement of imidazole with pyrrolidine (compound 126) led to an increase in potency $\left(\mathrm{IC}_{50}=24 \mathrm{nM}\right.$ ), but this compound displayed toxicity against $\mathrm{Hs} 68$ skin fibroblasts $\left(\mathrm{IC}_{50}: 77 \mathrm{nM}\right)$. The compound 125 analog RJ-LC-07-48 (127) displayed high potency with an $\mathrm{IC}_{50}$ value of $17 \mathrm{nM}$ against $\mathrm{H} 1975$ cells. When given by i.p. injection for 4 weeks, administration of compound 127 in the H1975 murine xenograft model resulted in average tumor volumes of $128.2 \mathrm{~mm}^{3}$ and $109.5 \mathrm{~mm}^{3}$ at doses of $1 \mathrm{mg} / \mathrm{kg}$ and $5 \mathrm{mg} / \mathrm{kg}$ in these groups, respectively, while the average tumor volume was $546.2 \mathrm{~mm}^{3}$ in the control group.

\subsection{Poly(ADP-Ribose)polymerase (PARP) Inhibitors}

PARP family enzymes play an important role in DNA repair, especially the repair of single strand breaks or the excision of a DNA base, by the transfer of ADP-ribose to target proteins from the substrate $\mathrm{NAD}^{+}$. If PARP activity is inhibited during DNA repair, single strand breaks result in the formation of double strand breaks (DSBs). Cells exhibiting DSBs require homologous recombination (HR) for DNA repair, making tumor cells that are deficient in HR (those harboring BRCA1 or BRCA2 mutations) sensitive to PARP inhibition. PARP is, thus, an inviting target in anticancer drug discovery (see References [121,122] for recent reviews on PARP and PARP inhibitors). Benzimidazole carboxamide derivatives developed by Min et al. were tested for PARP inhibition, as well as for cytotoxicity, against MDA-MB-436 (a BRCA1 mutant breast cancer cell line) and Capan-1 (a BRAC2-deficient pancreatic cancer cell line) [123]. Compounds 128, 129, and 130 were excellent PARP-1 and PARP-2 inhibitors, with IC $_{50}$ values of 5.9 and $4.5 \mathrm{nM}, 3.9$ and $4.2 \mathrm{nM}$, and 3.6 and $3.2 \mathrm{nM}$, respectively, whereas the known PARP inhibitor veliparib exhibited IC $\mathrm{IC}_{50}$ values of 5.3 and $1.6 \mathrm{nM}$ against PARP-1 and PARP-2. Compounds $\mathbf{1 2 9}$ and $\mathbf{1 3 0}$ displayed the highest potencies against the MDA-MB-436 and Capan- 1 cell lines, with $\mathrm{IC}_{50}$ values ranging from 11.4-19.8 $\mu \mathrm{M}$, while the $\mathrm{IC}_{50}$ values for veliparib were $>100 \mu \mathrm{M}$ against these cell lines. In this series, compounds possessing a phenyl ketone moiety exhibited the greatest potency against these cell lines, irrespective of the two to four carbon length of the linker between the pyrrolidine and phenyl rings. 


\subsection{Histone Deacetylase (HDAC) Inhibitors}

Histone deacetylases (HDACs) reverse the action of histone acetyltransferases by removing acetyl groups from lysine residues of both histone and nonhistone proteins. There are four classes of HDACs that deacylate lysine substrates via a $\mathrm{Zn}^{2+}$ or $\mathrm{NAD}^{+}$ dependent mechanism, and the abnormal expression of HDACs has been reported in various types of cancers. HDAC inhibitors have emerged as a class of anticancer agents capable of regulating gene expression, inhibiting DNA repair, causing growth arrest, inducing apoptosis, and inhibiting angiogenesis (see References [124-126] for reviews of HDACs and anticancer HDAC inhibitors). The utility of FDA-approved drugs, such as vorinostat, romidepsin, belinostat, and panobinostat, along with the challenges remaining concerning the use of these HDAC inhibitors for cancer treatment, have encouraged the design and synthesis of new compounds as selective HDAC inhibitors [127].

Chen et al. prepared thirty-one 6-phenylpurines linked to hydroxamate via an alkoxy chain of variable length [128]. Compound 131 (see Figure 12 for structures of compounds 131-141) exhibited promising activity against MV4-11 and PC-3 cancer cell lines, with $\mathrm{IC}_{50}$ values of 0.16 and $1.16 \mu \mathrm{M}$, respectively. This compound also showed excellent potency as an inhibitor of HDAC activity in HeLa cell nuclear extracts, with an $\mathrm{IC}_{50}$ value of $35 \mathrm{nM}$. By comparison, the known HDAC inhibitor vorinostat displayed an $\mathrm{IC}_{50}$ value of $57 \mathrm{nM}$ against HeLa nuclear extract-derived HDAC activity and $\mathrm{IC}_{50}$ values of 0.36 and $1.49 \mu \mathrm{M}$ against MV4-11 and PC-3 cancer cell lines, respectively. For these thirty-one derivatives, a positive correlation was shown between $\mathrm{HDAC} \mathrm{IC}_{50}$ and antiproliferative potency against the MV4-11 cell line, consistent with the hypothesis that the compounds evaluated target HDACs in these cancer cells. Compound $\mathbf{1 3 1}$ was also found to be a strong inhibitor of class I and IIb HDACs but a weak inhibitor of class IIa and IV HDACs. When compound 131 was evaluated against a panel of 97 kinases, $\geq 50 \%$ inhibitory activity was not observed for any of these kinases at a $1 \mu \mathrm{M}$ concentration of this compound. Histone $\mathrm{H} 3$ acetylation was increased in BALB/c nude mice bearing PC-3 tumors when compound 131 was administered orally to these animals at a dose of $150 \mathrm{mg} / \mathrm{kg}$.

Due to the proposed unique roles of HDAC6 in carcinogenesis (reviewed in Reference [129]), HDAC6 inhibitors are of interest as potential selective anticancer agents. Mackwitz et al. reported a multicomponent reaction using aldehydes, 2-aminopyridines, and methyl 4-isocyanobenzoate under microwave irradiation as a key step to access new imidazopyridine derivatives as candidate HDAC6 inhibitors [130]. These derivatives were screened for inhibition of human recombinant HDAC1 and HDAC6, as well as for activity against a human tongue squamous cell carcinoma cell line (CAL27). Compound 132 displayed $\mathrm{IC}_{50}$ values of $2.20 \mu \mathrm{M}$ against $\mathrm{HDAC} 1$ and $58 \mathrm{nM}$ against HDAC6 (selectivity index $=38$ ). Compound 133 displayed the best activity in a whole-cell HDAC inhibition assay employing CAL27 cells with an $\mathrm{IC}_{50}$ value of $1.75 \mu \mathrm{M}$. In terms of the SAR for these compounds, derivatives bearing an alkyl group at $\mathrm{C} 7$ of the imidazopyridine core displayed the highest selectivity for HDAC6 over HDAC1. The substituent present at C2 was less important in dictating cellular activity, however, as a subset of target compounds bearing substituents ranging from $\mathrm{H}$ (134) to 4-(dimethylamino)-1-naphthyl (133) at C2 displayed $\mathrm{IC}_{50}$ values in a narrow range $(3.22-4.78 \mu \mathrm{M})$ against CAL27 cells. The X-ray crystal structure of $\mathbf{1 3 2}$ bound to catalytic domain 2 from Danio rerio (zebrafish) HDAC6 revealed that the hydroxamate group of $\mathbf{1 3 2}$ was coordinated to the catalytic zinc ion.

Nepali et al. designed a new series of purine-benzamide compounds based on MS275 (135) and chidamide (136). These compounds were evaluated for their action on MDA-MB-231, MDA-MB-468, and HepG2 cell lines and also for HDAC inhibition [131]. Target compound 137 displayed IC $_{50}$ values of $1.48,0.65$, and $2.44 \mu \mathrm{M}$ against the MDAMB-231, MDA-MB-468, and HepG2 cell lines, respectively, while target compound 138 displayed $\mathrm{IC}_{50}$ values of 3.17 and $4.20 \mu \mathrm{M}$ against the MDA-MB-231 and HepG2 cell lines. By comparison, 135 and $\mathbf{1 3 6}$ displayed $\mathrm{IC}_{50}$ values of 2.60 and $3.60 \mu \mathrm{M}$ against the MDA-MB-231 cell line, respectively, and $4.54 \mu \mathrm{M}$ and $>8 \mu \mathrm{M}$ against HepG2 cells, respectively. When tested against $\mathbf{1 3 5}$ sensitive (YCC11) and $\mathbf{1 3 5}$ resistant (YCC3/7) gastric 
cancer cells, compound 137 displayed $\mathrm{IC}_{50}$ values of 4.77 and $4.79 \mu \mathrm{M}$, respectively, while the corresponding $\mathrm{IC}_{50}$ values for 135 were 6.03 and $12.98 \mu \mathrm{M}$, respectively. Compound 137 displayed selectivity towards HDAC1, 2, and 3, exhibiting $\mathrm{IC}_{50}$ values in the range $0.108-0.585 \mu \mathrm{M}$, while exhibiting $\mathrm{IC}_{50}$ values $>5 \mu \mathrm{M}$ against HDAC4-10. Western blotting studies revealed a dose-dependent elevation in histone $\mathrm{H} 3$ acetylation due to the incubation of compound 137 with MDA-MB-231 cells at concentrations ranging from $0.5-5 \mu \mathrm{M}$. In an MDA-MB-231 breast cancer xenograft model in mice, 56.3\% tumor growth inhibition was observed compared to the control group when compound 137 was administered at a dose of $50 \mathrm{mg} / \mathrm{kg}$ by i.p. injection daily for 23 days.<smiles>CC(C)n1cnc2c(-c3cccc(OCCCC(=O)NO)c3)nc(N3CCOCC3)nc21</smiles>

131<smiles>[R1]c1ccn2c(Nc3ccc(C(=O)NO)cc3)c([R])nc2c1</smiles>

134: $\mathrm{R}^{1}=\mathrm{Me}, \mathrm{R}^{2}=\mathrm{H}$<smiles>CN(C)c1ccc(-c2nc3ccccn3c2Nc2ccc(C(=O)NO)cc2)c2ccccc12</smiles>

133<smiles>[R]POc1ccc([R])cc1NC(=O)c1ccc(CNC([Y])=O)cc1</smiles>

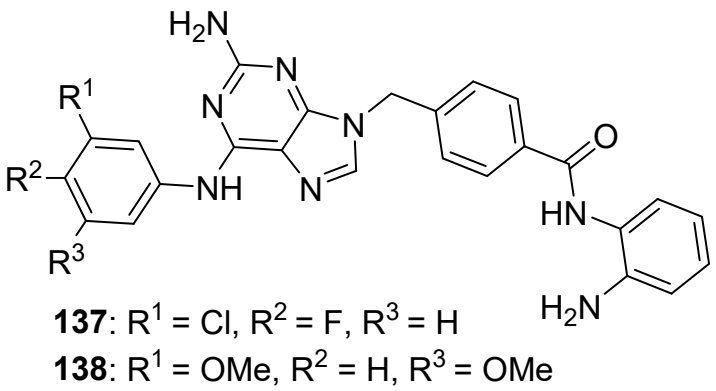<smiles>[R]c1ccc(NC(=O)Nc2ccc(Oc3ccc(C(=O)c4ncc[nH]4)cc3)cc2)cc1[R]</smiles>

139: $\mathrm{R}^{1}=\mathrm{CF}_{3}, \mathrm{R}^{2}=\mathrm{Cl}$ 140: $R^{1}=H, R^{2}=O M e$<smiles>Cc1ccc(Nc2nc(Cl)nc3c2ncn3Cc2ccc(C(=O)Nc3ccccc3N)cc2)cc1</smiles>

Figure 12. Imidazole-containing HDAC inhibitors reported in the literature (compounds 131-141).

Novel benzoylimidazole derivatives were synthesized as dual RAF/HDAC inhibitors and were screened for activity against five different human cancer cell lines [132]. Compounds 139 and 140 displayed the greatest potency, with $\mathrm{IC}_{50}$ values of $0.086 / 1.710 \mu \mathrm{M}$ and $1.853 / 0.635 \mu \mathrm{M}$ against $\mathrm{BRAF}^{\mathrm{V} 600 \mathrm{E}} / \mathrm{HDAC} 1$, respectively. Compounds $\mathbf{1 3 9}$ and 140 were further tested against RAF and HDAC isoforms, with compound 139 displaying IC $_{50}$ values of $0.045,0.134$, and $0.102 \mu \mathrm{M}$ against ARAF, ${ }^{\mathrm{w} t} \mathrm{BRAF}$, and CRAF isotypes, respectively. Compound 140 was less active against the RAF isoforms, while both of these compounds were inactive against HDAC6 and HDAC8 at a concentration of $50 \mu \mathrm{M}$. Compound 139 also displayed antiproliferative activity against A549, SK-Mel-2, and MV4-11 cell lines, with $\mathrm{IC}_{50}$ values of $9.11,5.40$, and $0.38 \mu \mathrm{M}$, respectively. By comparison, the $\mathrm{IC}_{50}$ values 
determined for SAHA (vorinostat) and sorafenib against these three cell lines were 18.1, 8.20, $0.11 \mu \mathrm{M}$ and 10.6, 9.30, $0.42 \mu \mathrm{M}$, respectively.

Yun et. al. reported a series of purine-based dual inhibitors of HDAC1/2 and CDK2 as potential multi-targeting anticancer agents and tested these compounds for activity against HCT116, HeLa, A375, HepG2, and H460 cancer cell lines [133]. The authors designed compounds by combining the aminobenzamide moiety common to one class of HDAC inhibitors with the purine-based pharmacophore present in CDK2 inhibitors. Of the target compounds, 141 was the most potent against four of the five cancer cell lines tested, displaying $\mathrm{IC}_{50}$ values ranging from $0.47-1.59 \mu \mathrm{M}$ against these cell lines. Compound 141 also displayed $\mathrm{IC}_{50}$ values of 70.7, 23.1, and $800 \mathrm{nM}$ against HDAC1, HDAC2, and CDK2, respectively. By comparison, the HDAC inhibitor CS055 displayed IC 50 values of 260 and $66.5 \mathrm{nM}$ against $\mathrm{HDAC} 1$ and $\mathrm{HDAC} 2$, respectively, while the CDK2 inhibitor roscovitine exhibited an $\mathrm{IC}_{50}$ value of $110 \mathrm{nM}$ against this enzyme. Docking simulations with $\mathbf{1 4 1}$ suggested hydrogen bonding interactions and coordination with the zinc ion are important for binding of the aminobenzamide moiety of this compound to HDAC1 and HDAC2, while hydrogen bonds formed by the purine ring and the 1,2-diaminobenzene moiety promote binding of compound $\mathbf{1 4 1}$ to CDK2. Antitumor activity for $\mathbf{1 4 1}$ was evaluated in a HCT116 xenograft colon cancer model in nude mice. When compound $\mathbf{1 4 1}$ was administered to these mice at 25,50 , and $100 \mathrm{mg} / \mathrm{kg}$ by i.p. injection once daily for 21 days, tumor growth inhibition of $28 \%, 40 \%$, and $44 \%$ was observed, respectively, compared to the control group.

\subsection{Lysine-Specific Demethylase 1 (KDM1A) Inhibitors}

Lysine-specific demethylase 1 (LSD1 or KDM1A) demethylates lysine residues (K4 and $\mathrm{K} 9$ ) of histone $\mathrm{H} 3$ protein and also regulates lysine methylation in other proteins. KDMA1 plays an important role in cancer cell growth and survival through the regulation of transcription, and the overexpression of KDMA1 has been associated with a range of cancers (reviewed in Reference [134]). KDMA1 has, thus, emerged as an anticancer target. New imidazolylthienopyrroles have been reported which act as reversible inhibitors of KDM1A [135]. Compound 142 (see Figure 13 for structures of compounds 142-153) displayed an $\mathrm{IC}_{50}$ value of $0.10 \mathrm{nM}$ against KDM1A. A dose-dependent increase in the expression of CD86, a biomarker related to KDMA1 inhibition, was also observed in THP- 1 cells treated with $\mathbf{1 4 2}$ at concentrations of 5 and $50 \mathrm{nM}$. In addition, $38.8 \%$ and $72.3 \%$ inhibition of colony formation was observed when THP-1 cells were treated with compound 142 at concentrations of 50 and $500 \mathrm{nM}$. When compound 142 was given orally at a dose of $30 \mathrm{mg} / \mathrm{kg} /$ day, 5 days a week for 2 weeks in separate murine models of acute promyelocytic and acute myeloid leukemia, survival in these groups of mice was prolonged by $55 \%$ and $70 \%$, respectively. 

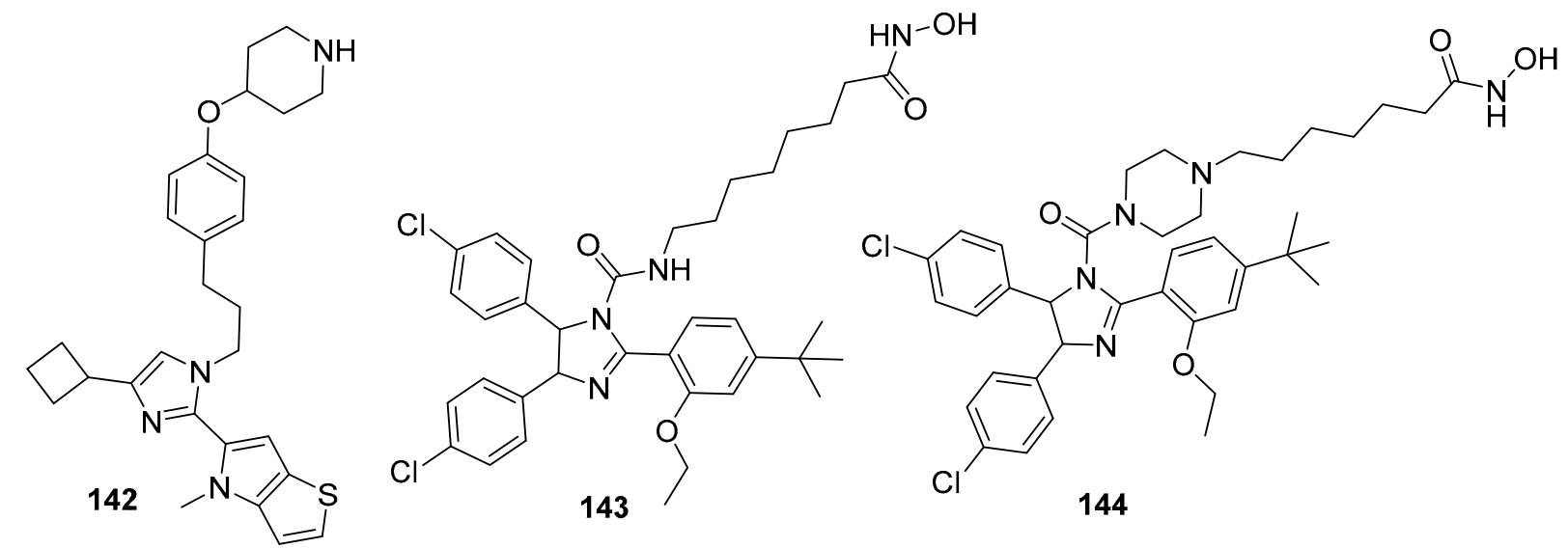<smiles>CCOc1cc(C(C)(C)C)ccc1C1=N[C@@H](c2ccc(Cl)cc2)[C@H](c2ccc(Cl)cc2)N1C(=O)N1CCN(CCCCCCC(=O)NO)CC1</smiles><smiles>CCOc1cc(C(C)(C)C)ccc1C1=N[C@@H](c2ccc(Cl)cc2)[C@H](c2ccc(Cl)cc2)N1C(=O)N1CCN(CCCCCCC(=O)NO)CC1</smiles><smiles>CCS(=O)(=O)Nc1ccc(Oc2ccc(F)cc2F)c(-c2cn(C)c(=O)c3cncn23)c1</smiles><smiles>[R]c1cc(CNC(=O)c2cc(Cn3ccn(C)c3=N)cc(-c3ccc(F)cc3C)c2)cc([R])c1[R]</smiles>

148: $R^{1}=R^{2}=C l, R^{3}=H$ 149: $R^{1}=R^{3}=$ OMe, $R^{2}=H$<smiles>COc1cc(CN2CCc3c(cc(Cn4ccn(C)c4=N)cc3-c3ccc(F)cc3C)C2=O)cc(OC)c1</smiles><smiles>[R][R]1cnc(NS(=O)(=O)c2cc(Br)cc(Cl)c2O)n1</smiles>

151: $\mathrm{R}^{1}=$ cyclohexyl, $\mathrm{R}^{2}=\mathrm{H}$

152: $R^{1}=$ cyclopentyl, $R^{2}=H$

153: $R^{1}=$ cyclopentyl, $R^{2}=\mathrm{SO}_{2} \mathrm{Me}$

Figure 13. Imidazole-containing compounds reported as inhibitors of KDMA1, MDM2, BET, and WDR5 (compounds 142-153).

\section{8. p53-Murine Double Minute 2 (MDM2) Inhibitors}

The transcription factor p53 plays a critical 'gate keeper' role in cancer suppression, while the murine double minute 2 (MDM2) protein is the major inhibitor of p53 within the cell. Interaction between MDM2 and wild-type p53 is responsible for inhibition of p53 function via three separate mechanisms: (1) direct binding to p53 resulting in inhibition of p53 binding to target DNA, (2) nuclear export of p53, and (3) ubiquitination of p53 via 
MDM2's E3 ligase activity. Several MDM2 inhibitors are in clinical trials, and the search for additional antagonists as anticancer candidates is in progress (see References [136,137] for reviews of MDM2 inhibition in cancer). He at al. designed and synthesized putative dual inhibitors of MDM2 and HDACs based on known substituted dihydroimidazole MDM2 inhibitors and HDAC inhibitors [138]. Compound 143 showed good activity toward both MDM2 $\left(\mathrm{K}_{\mathrm{i}}=0.34 \mu \mathrm{M}\right)$ and HDAC1 $\left(\mathrm{IC}_{50}=0.27 \mu \mathrm{M}\right)$. To improve binding affinity and solubility, piperazine and piperidine moieties were incorporated into the aliphatic chain. Compound 144 exhibited balanced activity, displaying a $\mathrm{K}_{\mathrm{i}}$ of $0.11 \mu \mathrm{M}$ against MDM2 and an $\mathrm{IC}_{50}$ value of $0.82 \mu \mathrm{M}$ against HDAC1. Testing of compounds for their antiproliferative activities against HCT116, MCF-7, A549, and NCI-H1299 cancer cell lines revealed the effect of compound 144 on the $\mathrm{A} 549$ cell line $\left(\mathrm{IC}_{50}=0.91 \mu \mathrm{M}\right)$ and the HCT116 cell line $\left(\mathrm{IC}_{50}=1.08 \mu \mathrm{M}\right)$. Compound 144 was selective for HDAC6 $\left(\mathrm{IC}_{50}=17.5 \mathrm{nM}\right)$ over HDAC1 $\left(\mathrm{IC}_{50}=821 \mathrm{nM}\right), \mathrm{HDAC} 2\left(\mathrm{IC}_{50}=421 \mathrm{nM}\right), \mathrm{HDAC} 3\left(\mathrm{IC}_{50}=178 \mathrm{nM}\right)$, and HDAC8 $(1224 \mathrm{nM})$. Chiral separation of compound 144 gave rise to isomers 145 and 146; the latter was more active. Compound 146 displayed 180 times greater potency towards MDM2 (K of $145=10.89 \mu \mathrm{M}$ and $\mathbf{1 4 6}=0.06 \mu \mathrm{M})$ and almost 10 times better antiproliferative activity against HCT116 $\left(\mathrm{IC}_{50}\right.$ value of $\mathbf{1 4 5}=10.03 \mu \mathrm{M}$ and $\left.\mathbf{1 4 6}=1.11 \mu \mathrm{M}\right)$ and $\mathrm{A} 549\left(\mathrm{IC}_{50}\right.$ value of $\mathbf{1 4 5}=9.02 \mu \mathrm{M}$ and $\mathbf{1 4 6}=0.99 \mu \mathrm{M})$ cell lines compared to $\mathbf{1 4 5}$. Similar activity was observed for the two isomers against HDAC1, however $\left(\mathrm{IC}_{50}\right.$ value of $\mathbf{1 4 5}=0.91 \mu \mathrm{M}$ and $146=0.89 \mu \mathrm{M}$ ). In an A549 xenograft model in nude mice, compound 144 exhibited $65.4 \%$ tumor growth inhibition when given orally at $100 \mathrm{mg} / \mathrm{kg} /$ day for 21 days, while tumor growth inhibition values of $57.3 \%$ and $44.0 \%$ were observed for the known HDAC and MDM2 inhibitors SAHA and Nutlin-3, respectively, when given by the same route and dosing regimen.

\subsection{Bromodomain and Extraterminal (BET) Protein Inhibitors}

The BET protein family (BRD2, BRD3, BRD4, and BRDT) plays an important role in oncogene expression. These proteins have tandem bromodomains (BD1 and BD2) that regulate gene expression through recognition of acetylated histone lysine residues, and disruption of this association by BET inhibitors is a promising approach in cancer drug discovery and development (see Reference [139] for a review of bromodomains as a drug target). Novel derivatives of 7-methylimidazopyrazinone synthesized by Yang et al. were evaluated for their activity against BET proteins and for their activity against a lymphoblast-like cell line (Raji), a leukemia cell line (HL-60), and a human pancreatic (BxPC-3) cancer cell line [140]. Compound 147 displayed $\mathrm{IC}_{50}$ values of $33 \mathrm{nM}$ against BRD4/BD1 and $25 \mathrm{nM}$ against BRD4/BD2 in vitro. This compound also exhibited an $\mathrm{IC}_{50}$ value of $110 \mathrm{nM}$ against the HL-60 cell line along with $43.2 \%$ inhibition of BxPC-3 cell proliferation at a concentration of $2 \mu \mathrm{M}$. In terms of the SAR for these molecules, replacement of the difluorophenyl substituent with a pyridyl group generally caused a significant decrease in potency. Western blotting analysis revealed that the treatment of BxPC-3 cells with compound 147 at concentrations of 5,10 , and $15 \mu \mathrm{M}$ caused upregulation of the BRD4 protein, caspase 3, and caspase 9, as well as downregulation of c-Myc and Bcl-xl, suggesting that compound 147 modulates apoptosis in this cell line.

\subsection{WD Repeat Domain 5 (WDR5) Inhibitors}

WDR5 belongs to the family of WD40 repeat (WDR) domain proteins, a group of proteins containing a central pocket for peptide binding that is amenable to the design of small molecule ligands. WDR5 is known to play a role in the transcriptional activation of oncogenes by facilitating histone methylation, resulting in the proliferation of cancer cells, tumor growth, and metastasis (see Reference [141] for a review of WDR domain proteins and Reference [142] for a review of WDR5 in cancer). The transcription factor MYC, a key driver of many tumors, has also been shown to rely on its interaction with WDR5 to bind to chromatin [143]. WDR5 has, thus, emerged as an attractive target for cancer therapeutics. 
Tian et al. synthesized new compounds based on dihydroimidazole imine $\mathbf{1 4 8}$ in which the structure-guided optimization of this compound led to improved WDR5 inhibitory activity, as well as anticancer activity [144]. Replacement of the 4-fluoro-2-methylpyridin-3-yl and 3,4-dichlorobenzyl moieties present in compound 148 with 4-fluoro-2-methylphenyl and 3,5-dimethoxy benzyl groups, respectively, resulted in compound 149. This compound exhibited potent WDR5 binding with a $K_{i}$ value of $0.049 \mathrm{nM}$, potent MLL1 histone methyltransferase inhibition $\left(\mathrm{IC}_{50}: 3.4 \mathrm{nM}\right.$ ), and antiproliferative activity with $\mathrm{GI}_{50}$ values of 15,000, 470, and $480 \mathrm{nM}$ against K562 leukemia, MV4-11, and MOLM-13 cell lines (the former cell line is p53 null, while the latter two MLL-fusion cell lines express wild-type p53). These values were similar to those obtained for compound 148. In general, substitutions at the 3,4 or 3,5 positions of the benzylamine group were optimal for WDR5 activity, as well as cellular inhibitory activity. Conformational restriction of the amide functionality occurring in compound 149 provided dihydroisoquinolinone containing compound 150, which displayed enhanced potency (WDR5 $\mathrm{K}_{\mathrm{i}}$ value of < $0.02 \mathrm{nM}$; MLL1 histone methyltransferase $\mathrm{IC}_{50}$ of $2.2 \mathrm{nM} ; \mathrm{GI}_{50}$ values of 8000, 38, and $78 \mathrm{nM}$ against K562, MV4-11, and MOLM-13 cell lines, respectively). Moreover, compound 150 displayed an improved K562:MV4-11 selectivity index of 210. Compound 150 also reduced the expression of the WDR5 bound genes RPS24 and RPL35 in MV4-11 cells treated with a $300 \mathrm{nM}$ concentration of this compound for 3 days; however, the expression of genes not bound to WDR5 (RPS11 and RPL14) was not reduced under these conditions. Moreover, treatment of MV4-11 cells with $600 \mathrm{nM}$ compound 150 resulted in reduced MYC binding to chromatin at the RPS24 and RPL35 genes. Compound 150 displayed antiproliferative activity in MYC-driven cancer cells with $\mathrm{GI}_{50}$ values of $0.26,0.49,0.24,1.2,0.58$, and $3.2 \mu \mathrm{M}$ against CHP-134, Ramos, Raji, Daudi, and SW620 cell lines, respectively, although the MYC expressing human colon cancer cell line SW480 was resistant to treatment with compound $\mathbf{1 5 0 .}$

Applying NMR-based fragment screening of ${ }^{15} \mathrm{~N}$-labeled WDR5 (consisting of amino acids 23-334), an imidazole sulfonamide (compound 151) was designed and synthesized that bound to WDR5 and disrupted the interaction between this protein and a fluorescent probe with a $\mathrm{K}_{\mathrm{d}}$ of $1.0 \mu \mathrm{M}$ [145]. To optimize the binding of compound 151 to WDR5, various hydrophobic substitutions were made at the N1 position of imidazole, leading to the synthesis of compound 152, which displayed a $\mathrm{K}_{\mathrm{d}}$ value of $0.40 \mu \mathrm{M}$. Replacement of imidazole with its isosteres and bioisosteres, such as 1,2,4-triazole, pyrazole, thiazole, and benzothiazole, led to either a modest or significant decrease in binding affinity. Further optimization of compound $\mathbf{1 5 2}$ via modification at the $\mathrm{C} 2$ position of imidazole resulted in the discovery of compound 153, which displayed a $\mathrm{K}_{\mathrm{d}}$ value of $0.10 \mu \mathrm{M}$. While small substitutions, such as methyl, ethyl, ethyl ester, and methyl sulfone, at the C2 position in compound 152 resulted in molecules possessing $\mathrm{K}_{\mathrm{d}}$ values in the range between $0.10-0.22 \mu \mathrm{M}$, placement of larger groups such as 4-substituted piperazine-amide and piperidine-amide led to a decrease in the $K_{d}$. Six of the seven active compounds disrupted the interaction between WDR5 and MYC in HEK-293 cell lysates in a co-immunoprecipitation assay at a concentration of $50 \mu \mathrm{M}$, while a structurally related compound showing no measurable WDR5 affinity $\left(\mathrm{K}_{\mathrm{d}}>40 \mu \mathrm{M}\right)$ did not disrupt the WDR5-MYC complex. Active compounds also inhibited the histone methyltransferase activity of MLL-1 when in complex with WDR5, RBBP5, ASH2L, and DPY30.

\subsection{Signal Transducer and Activator of Transcription 3 (STAT3) Inhibitors}

The transcription factor STAT3 is vital for cancer cell survival and proliferation. STAT3 is activated in many forms of cancer, resulting in the proliferation of cancer cells and, through the effect of STAT3 on its target genes, immunosuppression. Inhibition of STAT3 activity by small molecules can impede the growth of cancer cells, making STAT3 an important target in anticancer drug discovery (reviewed in Reference [146]).

A series of 2-imidazopyridines was synthesized and evaluated for activity against the PLC5 hepatoma cell line [147]. Of the synthesized compounds, 154, 155, and 156 (see Figure 14 for structures of compounds 154-172) displayed activity against this cell line 
with IC $_{50}$ values of $9.3 \mu \mathrm{M}, 10.4 \mu \mathrm{M}$, and $11.7 \mu \mathrm{M}$, respectively. Antiproliferative activity is greater when the compounds contain the imidazopyridine ring system rather than benzimidazole at the $\mathrm{C} 2$ position of pyrrole. Mechanistic studies employing $10 \mu \mathrm{M}$ concentrations of compounds 154, 155, and 156 revealed reduction of STAT3 phosphorylation in PLC5 cells. In addition, treatment of PLC5 cells with $10 \mu \mathrm{M}$ concentrations of these compounds increased the activity of SHP-1, a phosphatase that dephosphorylates and, thus, deactivates STAT3, by approximately 2-fold compared to control. The expression of survivin, cyclin D1, and MCL-1, which are downstream targets of STAT3, were also decreased upon treatment of PLC5 cells with compound $\mathbf{1 5 5}$ at concentrations of 5 and $10 \mu \mathrm{M}$.

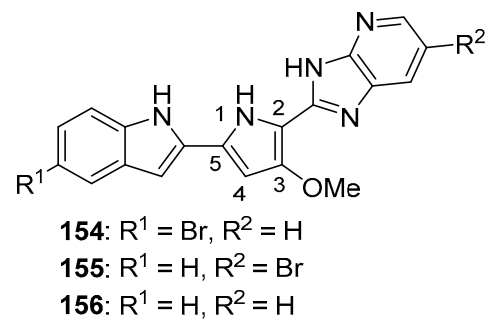<smiles>O=C(Nc1nc(NCc2ccc(Cl)cc2)c2nc[nH]c2n1)c1ccccc1</smiles>

PD26-TL07 (157)<smiles>C=C[AsH2]O[Mg]</smiles><smiles>Cn1cc(-c2ccc(N3CCC(C4c5c(F)cccc5-c5cncn54)CC3)cc2)cn1</smiles><smiles>Cn1cc(-c2ccc(N3CCC([C@@H]4c5c(F)cccc5-c5cncn54)CC3)cc2)cn1</smiles><smiles>C1=CCCC=C1</smiles><smiles>Cn1cc(-c2ccc(N3CCC([C@@H]4c5c(F)cccc5-c5cncn54)CC3)cc2)cn1</smiles>

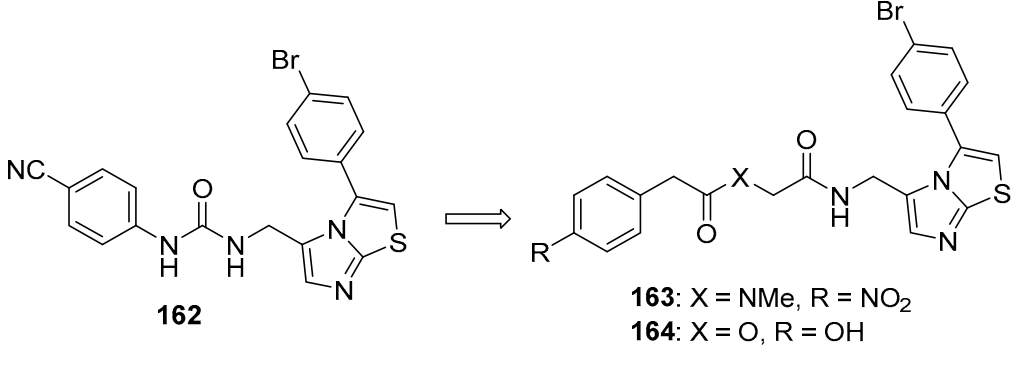<smiles>N#CCc1ccc(-c2cn(Cc3cnc4scc(-c5ccc(Br)cc5)n34)nn2)cc1</smiles><smiles>O=C(Cn1cc(C2CC2)nn1)NCc1cnc2scc(-c3ccc(Br)cc3)n12</smiles><smiles>O=C(NCc1cccc(Cn2cnc3ccccc32)c1)c1cc(Br)c[nH]1</smiles>

168<smiles>O=C(NCc1cccc(Cn2cnc3ccccc32)c1)c1cc2ccccc2[nH]1</smiles>

169<smiles>N#Cc1ccc(C(=O)NCc2cccc(Cn3cnc4ccccc43)c2)cc1</smiles><smiles>c1cn(Cc2cc(Cn3ccnc3)cc(Cn3ccnc3)c2)cn1</smiles><smiles>c1cn(Cc2ccc(Cn3ccnc3)cc2)cn1</smiles>

172

Figure 14. Imidazole-containing compounds reported as inhibitors of STAT3, IDO, and aromatase (compounds 154-172). 
Wang et al. synthesized C2,C6-disubstituted purines as potential anticancer agents targeting STAT3 [148]. The target compounds were tested for their antiproliferative activity against HCT116, SW480, and MDA-MB-231 cancer cell lines, as well as for their effects, on a human breast epithelial cell line (MCF-10A). PD26-TL07 (157) displayed potent antiproliferative activity with $\mathrm{IC}_{50}$ values of $1.77,1.51$, and $1.25 \mu \mathrm{M}$ against HCT116, SW480, and MDA-MB-231 cancer cells, respectively, while exhibiting low toxicity to MCF-10A cells $\left(\mathrm{IC}_{50}>100 \mu \mathrm{M}\right.$ ). IL6-induced phosphorylation of STAT3 was inhibited in MDA-MB231 cells treated with 1-10 $\mu \mathrm{M}$ concentrations of compound 157 as assessed by Western blotting, but the same concentrations of this compound had no effect on IL6-induced STAT1 phosphorylation. In an MDA-MB-231 murine xenograft model, administration of compound 157 (30 mg/kg by i.p. injection) resulted in a significant decrease in tumor weight compared to animals receiving vehicle (TGI of $47.8 \%$ ), while no difference in body weight between the two groups was observed.

\subsection{Indoleamine-2,3-Dioxygenase (IDO)/Tryptophan 2,3-Dioxygenase (TDO) Signaling Inhibitors}

IDO and TDO catalyze the oxidation of tryptophan to $\mathrm{N}$-formylkynurenine, the first step of tryptophan breakdown. Accumulation of tryptophan metabolites results in immunosuppression through multiple mechanisms, and the overexpression of the predominant IDO isoform (IDO1) occurs in some cancers. Since the immune system plays an important role in limiting cancer cell growth, invasion, and metastasis, compounds that inhibit IDO and TDO are of interest as anticancer candidates. While there are currently no approved drugs that function as IDO modulators, candidates, such as epacadostat, indoximod, and GDC-0919, are in various phases of clinical trials, and the identification of novel IDO1 and TDO inhibitors remains of interest in anticancer drug discovery (see Reference [149] for a review of IDO in cancer and cancer therapy).

Tu et al. synthesized new imidazoisoindole derivatives based on 158 (NLG-919), a dual inhibitor of IDO and TDO [150]. Among these derivatives, compound 159 displayed $\mathrm{IC}_{50}$ values of $26 \mathrm{nM}$ on IDO and $132 \mathrm{nM}$ on TDO in target-based assays and $101 \mathrm{nM}$ against the HeLa cell line in a phenotypic assay. In addition, compound 159 showed moderate inhibition of CYP3A4 $\left(\mathrm{IC}_{50}=8.4 \mu \mathrm{M}\right)$ and $\mathrm{IC}_{50}$ values $>10 \mu \mathrm{M}$ against four other CYP450 isoforms. Chiral separation of compound 157 gave rise to enantiomers 160 and 161. Among these, only compound 160 was active against IDO $\left(\mathrm{IC}_{50}=9.7 \mathrm{nM}\right)$ and $\mathrm{TDO}\left(\mathrm{IC}_{50}=47 \mathrm{nM}\right)$; this compound also displayed an $\mathrm{IC}_{50}$ value of $76 \mathrm{nM}$ against HeLa cells. A single $100 \mathrm{mg} / \mathrm{kg}$ oral dose of compound $\mathbf{1 6 0}$ administered to C57 mice caused a 57\% reduction in kynurenine (a metabolite formed in tryptophan breakdown) at $2 \mathrm{~h}$ after administration. At a $50 \mathrm{mg} / \mathrm{kg}$ oral dose of compound $\mathbf{1 6 0}$ given in an MC38 murine xenograft model twice daily for 14 days, $78 \%$ tumor growth inhibition was observed. Moreover, the combination of compound $\mathbf{1 6 0}$ given by the same dosing regimen, together with the anti-PD-1 (programmed death 1) monoclonal antibody SHR-1210 (administered i.p. at $5 \mathrm{mg} / \mathrm{kg}$ qod $\times 8$ ), displayed improved efficacy (TGI $>90 \%$ ) in the MC38 xenograft model.

Griglio et al. synthesized a series of imidazothiazole derivatives based on compound 162 (IDO1 $\mathrm{IC}_{50}=77 \mathrm{nM}$ ) [151], employing the Ugi and Passerini multicomponent reactions, and studied their inhibitory activities against IDO1 [152]. Some of these compounds displayed $\mathrm{IC}_{50}$ values below $1.0 \mu \mathrm{M}$ against the recombinant human IDO1 (rhIDO1) enzyme; among those, 163 and 164 displayed enzymatic $\mathrm{IC}_{50}$ values of 0.81 and $0.20 \mu \mathrm{M}$, respectively. However, only compound 163 displayed moderate inhibition ( $24 \%$ at a concentration of $10 \mu \mathrm{M})$ in an IDO cellular inhibition assay in the human melanoma A375 cell line, while other compounds were inactive in this assay. The authors speculated that poor solubility, avid serum protein binding, or efflux from the target cells may have led to the disconnect between inhibition of rhIDO1 activity and activity in the cell-based assay. In terms of the SAR for these compounds against rhIDO1, the placement of benzyl groups at the "left" side of the target molecules generally resulted in better inhibitory activity compared to derivatives possessing phenyl substitutions. Serafini et al. further extended the work by Griglio, synthesizing two additional series of imidazothiazole derivatives by replacing 
the benzylamide/benzyl ester moiety in 163 and 164 with 1,4-disubstituted 1,2,3-triazole and 1,2,3-triazole amides [153]. Of the synthesized imidazothiazole-1,4-disubstituted 1,2,3triazole derivatives, $\mathbf{1 6 5}$ and $\mathbf{1 6 6}$ displayed $\mathrm{IC}_{50}$ values of 0.5 and $1.1 \mu \mathrm{M}$ against rhIDO1, respectively, while, among triazole amide derivatives, compound 167 displayed an $\mathrm{IC}_{50}$ value of $0.2 \mu \mathrm{M}$ against this enzyme.

As a follow-up to these studies, Serafini et al. identified benzimidazoles as IDO1 inhibitors with the aid of a virtual screen of the IDO1 active site using the ZINC15 database [154]. Fifty of the top 500 molecules identified in this screen were purchased and evaluated in a cell-based assay measuring kynurenine levels in the A375 melanoma cancer cell line (which expresses high kynurenine levels when stimulated with INF- $\gamma$ ). Among these compounds, the hit molecule 168 displayed an $\mathrm{IC}_{50}$ value of $16 \mathrm{nM}$ in this assay. Compound 168 was resynthesized and subsequently displayed a $K_{d}$ value of $0.55 \mu \mathrm{M}$ against recombinant human IDO1, while epacadostat displayed a $K_{d}$ value of $3.46 \mu \mathrm{M}$ against this enzyme. The authors then designed a new series of molecules based on compound 168. The replacement of benzimidazole with indole led to a loss of activity, consistent with docking studies demonstrating a structural requirement for benzimidazole for IDO1 inhibition through heme binding at the active site. The replacement of the amide functionality with an ester group abolished activity, while replacement of pyrrole with furan and thiophene led to a decrease in potency. Of the derivatives synthesized, compounds 169 and 170 displayed potency comparable to compound 168 in the cellular IDO1 inhibition assay, with $\mathrm{IC}_{50}$ values of 72 and $90 \mathrm{nM}$, respectively. Further testing of compound 168 in a mastocytoma cell line expressing either murine TDO (P1.TDO) or IDO1 (P1.IDO1) showed that this compound displayed $\mathrm{IC}_{50}$ values of $5.46 \mu \mathrm{M}$ against P1.TDO and $12.7 \mathrm{nM}$ against P1.IDO1, with the assay being performed by measuring the secretion of L-kynurenine into the medium. Compounds 169 and $\mathbf{1 7 0}$ also displayed high selectivity for IDO1 over TDO in this assay. Compound 168 exhibited $\mathrm{IC}_{50}$ values ranging from $16-605 \mathrm{nM}$ against six cancer cell lines, while compounds 169 and 170 displayed $\mathrm{IC}_{50}$ values ranging from 72-140 nM and 90-1940 nM on a subset of three of these cell lines. Pretreatment of immunosuppressive monocytes taken from pancreatic ductal adenocarcinoma patients with $30 \mu \mathrm{M}$ concentrations of compounds 168 and 169 (a concentration that was not toxic to these monocytes) reduced the antiproliferative effect of the monocytes on $\mathrm{CD}^{+} \mathrm{T}$ cells.

\subsection{Aromatase Inhibitors}

Aromatase, a member of the CYP450 superfamily of enzymes, aids in the conversion of androgens to estrogen. The production of estrogen due to the action of the aromatase enzyme enhances tumor cell growth in hormone-dependent breast cancer, therefore aromatase inhibitors, such as letrozole, have been used clinically for the treatment of this type of cancer (see Reference [155] for a review of the use of aromatase inhibitors in breast cancer). Kalalinia et al. synthesized new azole derivatives as candidate aromatase inhibitors [156]. Neither the target compounds nor letrozole reached 50\% inhibitory activity against either MCF-7 or HepG2 cancer cell lines at a concentration of $100 \mu \mathrm{M}$. However, compounds 171 and $\mathbf{1 7 2}$ efficiently inhibited aromatase in cultured cells using a commercial estrone ELISA with $\mathrm{IC}_{50}$ values of $0.2 \mathrm{nM}$ and $6.8 \mathrm{nM}$, respectively, while letrozole displayed an $\mathrm{IC}_{50}$ value of $0.3 \mathrm{nM}$ in this assay (the cell line used was not specified). Compound $\mathbf{1 7 1}$ decreased androstenedione-induced uterine hypertrophy in immature female rats when administered orally at doses of 10,50 , and $100 \mu \mathrm{g} / \mathrm{kg}$ once a day for four days, while letrozole (given orally at $10 \mu \mathrm{g} / \mathrm{kg}$ ) produced a similar effect. In adult male rats treated with adrenocorticotropic hormone (ACTH, which stimulates cortisol and aldosterone production), a single oral dose of letrozole $(4 \mathrm{mg} / \mathrm{kg})$ significantly decreased serum concentrations of cortisol and aldosterone in comparison to control, while the same oral dose of compound $\mathbf{1 7 1}$ did not have significant effects on the serum concentration of these steroids, showing the specificity of compound $\mathbf{1 7 1 .}$ 


\subsection{Inhibition of Aldehyde Dehydrogenase}

Aldehyde dehydrogenase subtype 1A3 (ALD1A3) is overexpressed in high mortality glioblastomas and plays an important role in glioma cell invasion [157]. The inhibition of this enzyme may, thus, provide an attractive strategy for the treatment of certain brain tumors. Toward this end, Quattrini et al. synthesized novel derivatives of imidazopyridine targeting ALD1A3 [158]. The authors crystallized preliminary hit GA11 (173) (see Figure 15 for structures of compounds 173-184) with human recombinant ALDH1A3 to aid inhibitor design. Analogs 174-177 displayed selectivity towards ALDH1A3, with $\mathrm{IC}_{50}$ values of 22.8, $17.8,21.2$, and $6.4 \mu \mathrm{M}$, respectively, while displaying no significant inhibition of aldehyde dehydrogenase subtypes ALD1A1 and ALD1A2 when tested at concentrations of $25 \mu \mathrm{M}$. Of these compounds, $\mathbf{1 7 4}$ displayed the greatest potency against human patient-derived glioma specimens with $\mathrm{IC}_{50}$ values of $25.2 \mathrm{nM}, 63.4 \mathrm{nM}$, and $2.58 \mathrm{pM}$ against PN-157, MES-267, and MES-374 cells, respectively.

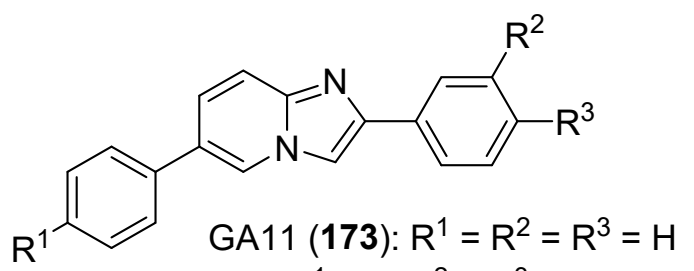

174: $R^{1}=F, R^{2}=R^{3}=H$

$\mathrm{Br}^{\prime}$<smiles>OC(Cn1ccnc1)c1cccc(OCc2ccc(Br)cc2)c1</smiles>

175: $R^{1}=$ OMe, $R^{2}=R^{3}=H$

176: $R^{1}=F, R^{2}=O M e, R^{3}=H$

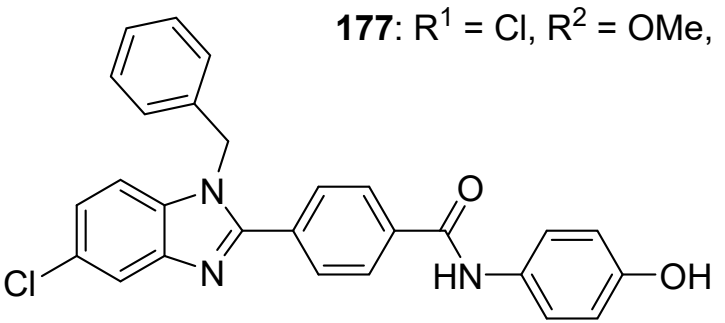

179<smiles>Oc1cccc(-n2cc(COc3ccc(-c4nc5cc(Cl)ccc5n4Cc4ccccc4)cc3)nn2)c1</smiles>

180<smiles>c1ccc2[nH]c(-c3ccno3)nc2c1</smiles>

181<smiles>[R]c1ccc(-c2nc3ccccc3[nH]2)nc1C</smiles>

182: $\mathrm{R}=\mathrm{COCH}_{3}$

183: $\mathrm{R}=\mathrm{COOC}_{2} \mathrm{H}_{5}$<smiles></smiles>

184

Figure 15. Imidazole-containing compounds reported as inhibitors or putative inhibitors of ALD1A3, HO-1, galectin-1, and GST (compounds 173-184).

\subsection{Heme Oxygenase-1 (HO-1) Inhibitors}

HO-1 participates in the degradation of heme; overexpression of this enzyme is linked to protective effects on cancer cells and may promote cancer progression, cancer cell growth and survival, and metastasis (see Reference [159] for a review of HO-1 as an anticancer target). Ciaffaglione et al. synthesized a series of arylethanolimidazole-based derivatives as candidate HO-1 inhibitors [160]. Compound $\mathbf{1 7 8}$ displayed significant activity against HO-1, exhibiting an $\mathrm{IC}_{50}$ value of $0.90 \mu \mathrm{M}$. In terms of the SAR for these compounds, removal or oxidation of the hydroxyl group led to diminished activity against HO-1. Compound 178 exhibited moderate potency against the hormone-sensitive MCF-7 cell 
line $\left(\mathrm{IC}_{50}=47.4 \mu \mathrm{M}\right)$, while this compound was inactive against the hormone-resistant MDA-MB-231 cancer cell line.

\subsection{Galectin-1 Inhibitors}

Galectin-1 is a carbohydrate-binding protein that plays an important role in tumor invasion, progression, metastasis, and angiogenesis when overexpressed (reviewed in Reference [161]). Thus, galectin-1 inhibition is a potential anticancer strategy. Goud et al. synthesized 1-benzyl-benzimidazole derivatives as potential galectin-1 targeted anticancer agents and evaluated their activity against MDA-MB-231, A549, MCF-7, DU-145, HT29, and HCT116 cancer cell lines [162]. Compound $\mathbf{1 7 9}$ was as active as any of the target compounds against MCF-7 cells, exhibiting an $\mathrm{IC}_{50}$ value of $7.01 \mu \mathrm{M}$ against this cell line. Treatment of MCF-7 cells with compound $179(10-300 \mu \mathrm{M})$ caused a dose-dependent reduction of the expression of Gal-1 protein as determined by ELISA; the binding of compound 179 with the galectin-1 protein was confirmed by fluorescence spectroscopy and surface plasmon resonance experiments. In an extension of this work, benzimidazole-1,2,3-triazole hybrid compounds were synthesized as galectin- 1 targeted agents based on compound 179 and were evaluated for their activity against NCI-H460, A549, MDA-MB-231, and MCF-7 cancer cell lines [163]. Target compound 180 displayed $\mathrm{IC}_{50}$ values of $0.99,0.63,0.94$, and $1.3 \mu \mathrm{M}$ against these four cell lines, respectively. Indicators of apoptosis were observed in A549 cells treated with compound $\mathbf{1 8 0}$ at $0.5-2.5 \mu \mathrm{M}$ concentrations, including damage to the nucleus along with dose-dependent increases in sub- $\mathrm{G}_{1}$ cells and annexin $\mathrm{V}$ positive cells. Incubation of A549 cells in the presence of compound 180 at concentrations ranging from $10-300 \mu \mathrm{M}$ resulted in a dose-dependent decrease in galectin-1 expression as determined by ELISA. Surface plasmon resonance and fluorescence spectroscopy studies indicated the binding of compound $\mathbf{1 8 0}$ to galectin-1.

\subsection{Glutathione S-Transferase Inhibitors}

Glutathione S-transferase (GST) is best known as a phase 2 metabolic enzyme involved in the detoxification of electrophiles. The non-hepatic GSTP1 isotype is abundantly expressed in some cancers and may be responsible for anticancer drug resistance by deactivating electrophilic drugs or by influencing cell signaling pathways (reviewed in Reference [164]). GSTP1 inhibitors may, thus, be useful for treating some forms of cancer, as well as for reversing resistance. Abd El-Karim et al. synthesized new benzimidazoles with the goal of inhibiting GST as an anticancer strategy [165]. Compounds 181 and 182 displayed IC $_{50}$ values of $1.7 \mu \mathrm{g} / \mathrm{mL}$ and $0.67 \mu \mathrm{g} / \mathrm{mL}$, respectively, against the GST enzyme prepared from human placenta, while the standard ethacrynic acid exhibited an $\mathrm{IC}_{50}$ value of $5.5 \mu \mathrm{g} / \mathrm{mL}$. In general, placement of isoxazole or a 2-pyridyl group at the C2 position of benzimidazole resulted in greater potency against GST, while placement of pyrazole or $\mathrm{N}$-methyl pyrazole at this position led to a decrease in potency. Compounds $\mathbf{1 8 3}$ and $\mathbf{1 8 4}$ displayed the greatest potency against the MCF-7 cell line ( $\mathrm{IC}_{50}$ values of 3.2 and $2.7 \mu \mathrm{g} / \mathrm{mL}$, respectively), while these compounds exhibited $\mathrm{IC}_{50}$ values of 3.7 and $4.9 \mu \mathrm{g} / \mathrm{mL}$ against the HCT cell line, respectively. These results indicate that compounds $\mathbf{1 8 3}$ and $\mathbf{1 8 4}$ may act on a target distinct from GST or that compounds $\mathbf{1 8 1}$ and $\mathbf{1 8 2}\left(\mathrm{IC}_{50}\right.$ values of 7.5 and $15.5 \mu \mathrm{g} / \mathrm{mL}$ against MCF-7 cells, respectively) may exhibit poor permeability to these cancer cell lines. Molecular docking studies revealed good binding between compounds 181 and 182 and GSTP1.

\subsection{Lipoxygenase Inhibitors}

Lipoxygenases (LOXs) catalyze the conversion of polyunsaturated fatty acids into fatty acid hydroperoxides. With arachidonic acid as a substrate, different LOX isotypes can perform this oxidation at different sites of unsaturation. Since the 15-LOX isotype has been implicated in several forms of cancer, 15-LOX inhibitors are of interest as new anticancer candidates (see Reference [166] for a review of anticancer 15-LOX inhibitors). Afifi et al. described the synthesis and evaluation of purine-pyrazole hybrids as potential inhibitors of 
the 15-LOX isoform [167]. The target compounds exhibited $\mathrm{IC}_{50}$ values against 15-LOX in the range 1.76-6.12 $\mu \mathrm{M}$. These compounds were also screened for in vitro activity against the MCF-7, PC-3, A549, HepG2, and Caco-2 cancer cell lines. Of the compounds tested, 185 was the most potent against all five cancer cell lines, exhibiting $\mathrm{IC}_{50}$ values ranging from 18.5-23.4 $\mu \mathrm{M}$. While compound 185 (see Figure 16 for structures of compounds 185-191) was one of the stronger 15-LOX inhibitors identified $\left(\mathrm{IC}_{50}=2.33 \mu \mathrm{M}\right)$, it displayed the best antioxidant activity in an assay measuring the reduction of 2,2'-diphenyl-1-picrylhydrazyl, displaying an $\mathrm{IC}_{50}$ value of $0.93 \mu \mathrm{g} / \mathrm{mL}(1.64 \mu \mathrm{M})$ in this assay. In molecular docking studies, compound 185 bound to 15-LOX (PDB ID code: 1-LOX) with a docking score of $-3.37 \mathrm{kcal} / \mathrm{mol}$.<smiles>CCn1c(-n2cc(/C=N/N=C3\SCC(=O)N3c3ccccc3)c(-c3ccccc3)n2)nc2c1c(=O)n(C)c(=O)n2C</smiles>

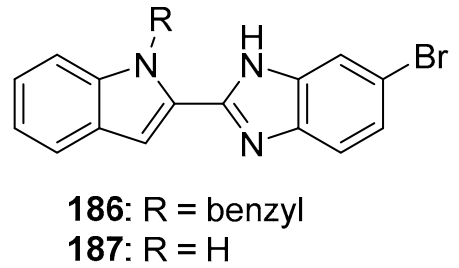<smiles>Cc1cc(Nc2ccc(F)cc2)n2ncnc2n1</smiles>

WS-36 (188)<smiles>Cc1cc(Nc2ccc(F)cc2)n2nc(SCc3nc4ccccc4[nH]3)nc2n1</smiles>

WS-691 (189)<smiles>NC(=O)c1ccc(-n2ccc3c(-c4cnc5ccccc5c4)cccc32)cc1NC1CCC(O)CC1</smiles><smiles>CCc1cc(C(N)=O)ccc1-n1nc(C(C)C)c2c(-n3cnc(-c4cnn(C)c4)c3)ccnc21</smiles>

Figure 16. Imidazole-containing compounds reported as inhibitors of LOX-15, ER- $\alpha$, ABCB1, and HSP (compounds 185-191).

\subsection{Estrogen Receptor- $\alpha$ (ER- $\alpha)$ Inhibitors}

As stated in Section 4.13, estrogen plays a vital role in mammary tumorigenesis. The effect of estrogen is mediated by estrogen receptors $\alpha$ and $\beta$ (ER- $\alpha$ and ER- $\beta$ ); in most breast cancers, initiation and progression of tumors occurs by the activation of ER- $\alpha$. Compounds, such as tamoxifen, which selectively bind to ER- $\alpha$, thus, provide an important strategy for the treatment of breast cancer (see Reference [168] for a review of the use of ER- $\alpha$ antagonists in breast cancer). Singla et al. synthesized a series of indole-benzimidazole derivatives and examined their activity using the ER- $\alpha$ responsive T47D breast cancer cell line and an ER- $\alpha$ binding assay [169]. Target compounds 186 and 187 displayed IC $_{50}$ values of 15.48 and $4.99 \mu \mathrm{M}$, respectively, against T47D cells; these molecules were more potent than the standard compound bazedoxifene $\left(\mathrm{IC}_{50}=16.43 \mu \mathrm{M}\right)$. Upon analysis of the 
structural features of these molecules, it was observed that bromoimidazole derivatives 186 and 187 were more potent than their unsubstituted imidazole analogs and significantly more potent than analogs containing an imidazopyridine ring system. Compounds 186 and 187 displayed affinity for ER- $\alpha$, with $\mathrm{IC}_{50}$ values of 73.61 and $80.36 \mathrm{nM}$, respectively, in a competitive binding assay (the $\mathrm{IC}_{50}$ of bazedoxifene in this assay was $31.71 \mathrm{nM}$ ). Expression of ER- $\alpha$ mRNA and ER- $\alpha$ protein were both diminished by treatment of T47D cells with $15 \mu \mathrm{M}$ and $5 \mu \mathrm{M}$ concentrations of compounds 186 and 187, respectively.

\subsection{0. $A B C B 1$ Inhibitors}

Multidrug resistance (MDR) is a major cause of failure in cancer chemotherapy, as efflux of intracellular drugs by P-gp (the drug transporter MDR1 or ABCB1; overexpressed in multidrug resistant cancer cells) causes a decrease in the intracellular drug concentration (reviewed in Reference [170]). Thus, the modulation of ABCB1 activity has been explored as a strategy for cancer treatment. In this regard, Wang et al. designed new molecules based on WS-36 (188), which increases sensitization of the ABCB1-overexpressing SW620/Ad300 cell line to paclitaxel [171]. The combination of compound $188(20 \mu \mathrm{M}$, a nontoxic concentration alone) with paclitaxel was toxic to SW620/Ad300 cells with an $\mathrm{IC}_{50}$ value of $2.34 \mu \mathrm{M}$, while paclitaxel alone displayed an $\mathrm{IC}_{50}$ value of $4.23 \mu \mathrm{M}$ against this cell line. Various structural modifications at $\mathrm{C} 8, \mathrm{C} 6$, and $\mathrm{C} 2$ of the triazolopyrimidine core of compound 188 were carried out, resulting in the identification of compound WS-691 (189) as the most potent derivative. Paclitaxel displayed an $\mathrm{IC}_{50}$ value of $0.022 \mu \mathrm{M}$ in combination with compound $189(20 \mu \mathrm{M}$, a nontoxic concentration when given alone), while paclitaxel in combination with the first-generation ABCB1 modulator verapamil $(4 \mu \mathrm{M})$ displayed an $\mathrm{IC}_{50}$ value of $0.30 \mu \mathrm{M}$. In terms of the SAR, placement of a thiomethyl group at the C2 position of the triazolopyrimidine core leads to higher potency compared to larger thioalkyl groups, while, among the various substituted anilines at the C7 position, only molecules substituted with 4-fluoroaniline (compound 189) or aniline displayed potent MDR reversal activity. In studies employing the KB-3-1 cell line and its corresponding multidrug resistant cell line KB-C2 (which overexpresses ABCB1), a complete reversal of paclitaxel resistance was observed in $\mathrm{KB}-\mathrm{C} 2$ cells at a $20 \mu \mathrm{M}$ concentration of compound 189. At concentrations of 10 and $20 \mu \mathrm{M}$, compound 189 increased the intracellular concentration of paclitaxel in ABCB1-overexpressing SW620/Ad300 cells compared to cells that were not exposed to this compound. Compound 189 did not inhibit the critical drug metabolizing enzyme CYP3A4 when tested at a concentration of $30 \mu \mathrm{M}$, in contrast with verapamil. In a SW620/Ad300 murine xenograft model, compound 189 (administered at $20 \mathrm{mg} / \mathrm{kg} /$ day for 21 days by intragastric injection) in combination with paclitaxel caused a reduction in tumor volume and tumor weight that was greater than the effect of paclitaxel alone.

\subsection{Heat Shock Protein (HSP) Inhibitors}

HSPs are molecular chaperones which play important roles in protein folding and also protect protein structure and function during cellular stress. Cancer cells depend heavily on HSPs for survival, thus making these chaperones important targets for cancer therapeutics. HSP90 has been the subject of most of these drug discovery and development efforts. While a number of HSP90 inhibitors are undergoing clinical trials, there are currently no approved anticancer drugs that act on this pathway, highlighting the need for further investigation of small molecules targeting HSPs (see References [172,173] for reviews focusing on the targeting of HSPs and HSP90, respectively). Uno et al. reported a series of molecules based on preliminary hit 190 as potential HSP90 inhibitors [174]. Compound 190 was a hybrid compound designed from the X-ray crystal structures of two previous inhibitors of HSP90. The authors explored the indole nucleus in compound $\mathbf{1 9 0}$ and also examined the effect of the 3-quinoline group. The former strategy revealed pyrazolopyridine as the optimal core, and the latter strategy showed that the best results were obtained through the replacement of quinoline with substituted imidazole. Further optimization showed that the best overall activity against $\mathrm{HSP} 90 \alpha\left(\mathrm{IC}_{50}=69 \mathrm{nM}\right)$ in conjunction with effectiveness against the SK- 
BR-3 cell line $\left(\mathrm{IC}_{50}=330 \mathrm{nM}\right)$, and good oral exposure in mice $\left(\mathrm{AUC}_{0-6 \mathrm{~h}}=90.1 \mu \mathrm{M} \cdot \mathrm{h}\right.$ at a dose of $50 \mathrm{mg} / \mathrm{kg}$ ) was achieved when the $\mathrm{C} 4$ position of imidazole was substituted with $\mathrm{N}$-methyl pyrazole and the $\mathrm{C} 2$ position of the phenyl ring attached to imidazopyridine was substituted with an ethyl group (compound 191). After oral administration of compound 191 in an NCI-H1975 murine xenograft model at a dose of $10 \mathrm{mg} / \mathrm{kg} /$ day for 14 days, the tumor volume in control animals was approximately four times greater than in animals receiving compound 191. Western blotting studies of tumor proteins from this in vivo study revealed that treatment with compound 191 resulted in decreased levels of the HSP90 client protein EGFR, thus inhibiting downstream phosphorylation of AKT, RPS6, and MAPK 1/3.

\section{Anticancer Activities Shown by Imidazole Derivatives through Undefined Mechanisms}

\subsection{Benzimidazolium Salts}

Karatas et al. synthesized coumarin substituted benzimidazolium salts and tested their cytotoxicities against PC-3 (prostate) and A2780 (ovarian) cancer cell lines [175]. Some of the synthesized compounds were found to have good cytotoxic activity in the PC-3 cancer cell line. PC-3 cells exposed to a $1 \mu \mathrm{M}$ concentration of compound 192 (see Figure 17 for structures of compounds 192-199) displayed a viability by $44.53 \%$, while the viability of these cells exposed to $1 \mu \mathrm{M}$ docetaxel was $31.45 \%$.<smiles></smiles>

192<smiles></smiles>

193: $\mathrm{R}=\mathrm{Br}$

194: $\mathrm{R}=\mathrm{OMe}$<smiles>Cc1cc2c(cc1C)[n+](CC(=O)c1ccc3ccccc3c1)cn2C(c1ccccc1)c1cc2ccccc2oc1=O</smiles>

195<smiles>Cc1ccc(C[n+]2cn(CCNC3CCCCC3)c3ccccc32)cc1</smiles>

196<smiles>Cl[n+]1cn(CCN2CCCCC2)c2ccccc21</smiles>

197<smiles>COc1cc(/C=C/C(=O)c2ccc(OCCCn3c[n+](Cc4ccc(C)cc4)c4cc(C)c(C)cc43)cc2)cc(OC)c1OC</smiles>

Figure 17. Benzimidazolium salts with anticancer activity (compounds 192-199).

Wang et al. synthesized a related series of 3-benzylcoumarin-imidazolium salts and evaluated their in vitro cytotoxicity against A549, HL-60, SMMC-7721, MCF-7, and SW480 cancer cell lines [176]. Compounds 193 and 194 exhibited potent activity on SW480 cells, displaying $\mathrm{IC}_{50}$ values of 0.20 and $0.36 \mu \mathrm{M}$, respectively, while compound 195 was active against all the cancer cell lines tested ( $\mathrm{IC}_{50}$ values ranging from $2-5 \mu \mathrm{M}$ ). In terms of antiproliferative SAR, the activity pattern with respect to the central benzimidazole ring followed the general trend (starting with the most potent) 5,6-dimethyl 
benzimidazole $>$ benzimidazole $>2$-methyl benzimidazole $>$ imidazole. In the compounds possessing 5,6-dimethyl benzimidazole and 2-methyl benzimidazole, compounds containing substitutions with phenacyl, 4-bromophenacyl, 4-trifluoromethylphenacyl, 4-methoxyphenacyl, 4-phenylphenacyl, and naphthylacyl generally displayed the most potent activities $\left(\mathrm{IC}_{50}\right.$ values $\left.<10 \mu \mathrm{M}\right)$. Compound 195 caused apoptosis in the SMMC-7721 cell line at concentrations of $4 \mu \mathrm{M}$ and $8 \mu \mathrm{M}$.

A series of piperidinylethyl-benzoimidazolium derivatives was synthesized by Akkoç et al. and was examined for cytotoxicity on Beas-2B, HEK-293T, DLD-1, HepG2, and MDAMB-231 cancer cell lines [177]. Compound 196 displayed $\mathrm{IC}_{50}$ values of $17.80 \mu \mathrm{M}$ and $15.16 \mu \mathrm{M}$ on DLD-1 and HepG2 cell lines, respectively, while compound 197 exhibited $\mathrm{IC}_{50}$ values of 15.56 and $10.45 \mu \mathrm{M}$ on DLD-1 and Beas-2B cell lines, respectively. The remaining compounds displayed $\mathrm{IC}_{50}$ values $>20 \mu \mathrm{M}$ on all the cell lines tested.

Yang et al. designed, synthesized, and tested the anticancer activity of chalconebenzimidazolium salts on five different human cancer cell lines [178]. Chalcone-imidazoles showed activity in the range $1.08-5.87 \mu \mathrm{M}$; however, their imidazolium salts proved to be more potent. The hybrid imidazolium salt 198, possessing a naphthyl methyl substitution, and 199, bearing a 4-methyl benzyl substitution, displayed the most potent $\mathrm{IC}_{50}$ values of $0.83 \mu \mathrm{M}$ and $0.59 \mu \mathrm{M}$ against HL-60 cell lines. Compound 198 exhibited IC 50 values of 1.57 and $2.92 \mu \mathrm{M}$ against MCF-7 and SW480 cell lines and was 11.1-fold and 5.8-fold more potent than cisplatin in the MCF-7 and SW- 480 cell lines, respectively. Regarding substitution on the benzimidazole ring system, the order of activity was 5,6-dimethyl $>2$ methyl > unsubstituted, while the substitutions on nitrogen, in general, followed the order napthyl $>$ benzyl $>$ phenacyl from most potent to least potent. Compound 198 also induced accumulation of SMMC-7721 cells in the $\mathrm{G}_{0} / \mathrm{G}_{1}$ phase at 2.5 and $5.0 \mu \mathrm{M}$ concentrations and dose-dependent apoptosis in these cells at 5.0 and $10.0 \mu \mathrm{M}$ concentrations.

\subsection{Benzimidazole Containing and Related Molecules}

The in vitro antitumor potency of a new series of benzimidazole-quinolinone derivatives was evaluated against HepG2, SKOV3, NCI-H460, and BEL-7404 cancer cell lines along with the toxicity of these molecules against the HL-7702 normal human liver cell line [179]. Compounds 200 and 201 (see Figure 18 for structures of compounds 200-220) exhibited the highest potency on HepG2 and BEL-7404 cell lines, with $\mathrm{IC}_{50}$ values of $8.45 \mu \mathrm{M}$ and $9.06 \mu \mathrm{M}$, respectively. In terms of the SAR, the placement of an ethylenedioxy substitution at the 6,7 position of quinoline led to greater anticancer activity, while halide substitution on the benzimidazole portion increased activity compared to unsubstituted compounds or compounds with a methyl substitution. Treatment of HepG2 cells with 200 or 201 caused activation of p53 protein, caspase-3 and caspase-9, up-regulation of Bax/downregulation of Bcl-2, cleavage of PARP, and inhibition of CDK activity. In a murine NCI-460 xenograft model, compound $200(50 \mathrm{mg} / \mathrm{kg}$ twice a day given by i.p. injection for 13 days) resulted in $66.9 \%$ reduction in tumor weight, while the standard drug cisplatin ( $2 \mathrm{mg} / \mathrm{kg}$ for 2 days by i.p. injection) reduced tumor weight by $63.2 \%$ in the same model. Administration of compound 201 ( $50 \mathrm{mg} / \mathrm{kg}$ given by i.p. injection for 13 days) resulted in $44.9 \%$ reduction in tumor weight in a BEL-7402 murine xenograft model, while administration of 5-FU ( $25 \mathrm{mg} / \mathrm{kg}$ for 2 days by i.p. injection) led to $34.5 \%$ tumor weight reduction in this model. 
<smiles>O=c1[nH]c2ccccc2cc1-c1nc2cc(Cl)ccc2[nH]1</smiles>

200<smiles>CCOC(=O)C(C(C)=O)=C1SC=C(n2c(CC#N)nc3ccccc32)N1c1ccccc1</smiles>

204<smiles>COc1ccc(C(=O)/C=C/c2nc3ccccc3n2C)cc1</smiles>

209<smiles>O=c1[nH]c2cc3c(cc2cc1-c1nc2cc(Cl)ccc2[nH]1)OCCO3</smiles>

201<smiles>[R]CC(=O)n1c(CC#N)nc2ccccc21</smiles>

202: $\mathrm{R}=\mathrm{NHNH}_{2}$ 203: $R=C N$<smiles>[R]c1ccc(N/N=C(\Cl)C(=O)n2c(-c3cc4ccccc4oc3=O)nc3ccccc32)c([R])c1</smiles>

205: $R^{1}=R^{2}=C l$

206: $R^{1}=N_{2}, R^{2}=H$<smiles>NNc1ccccc1</smiles><smiles>COc1ccc(C2=NNC(c3nccn3C)C2)cc1</smiles>

210<smiles>[R]c1ccc(C(=O)/C=C/c2nccn2C)cc1</smiles>

207: $\mathrm{R}=\mathrm{OMe}$

208: $R=F$<smiles>[R]Cn1c(C(=O)/C=C/c2ccccc2)nc2ccccc21</smiles>

211: $\mathrm{n}=2, \mathrm{R}=$ pyrrolidine

212: $n=2, R=$ piperidine 213: $n=3, R=$ morpholine<smiles>Cc1[nH]c(-c2nc3ccccc3[nH]2)c(C)c1C(=O)NC(C)C1CCCCC1</smiles>

214<smiles>Cc1[nH]c(-c2nc3ccccc3[nH]2)c(C)c1C(=O)N1CCc2sccc2C1</smiles>

215

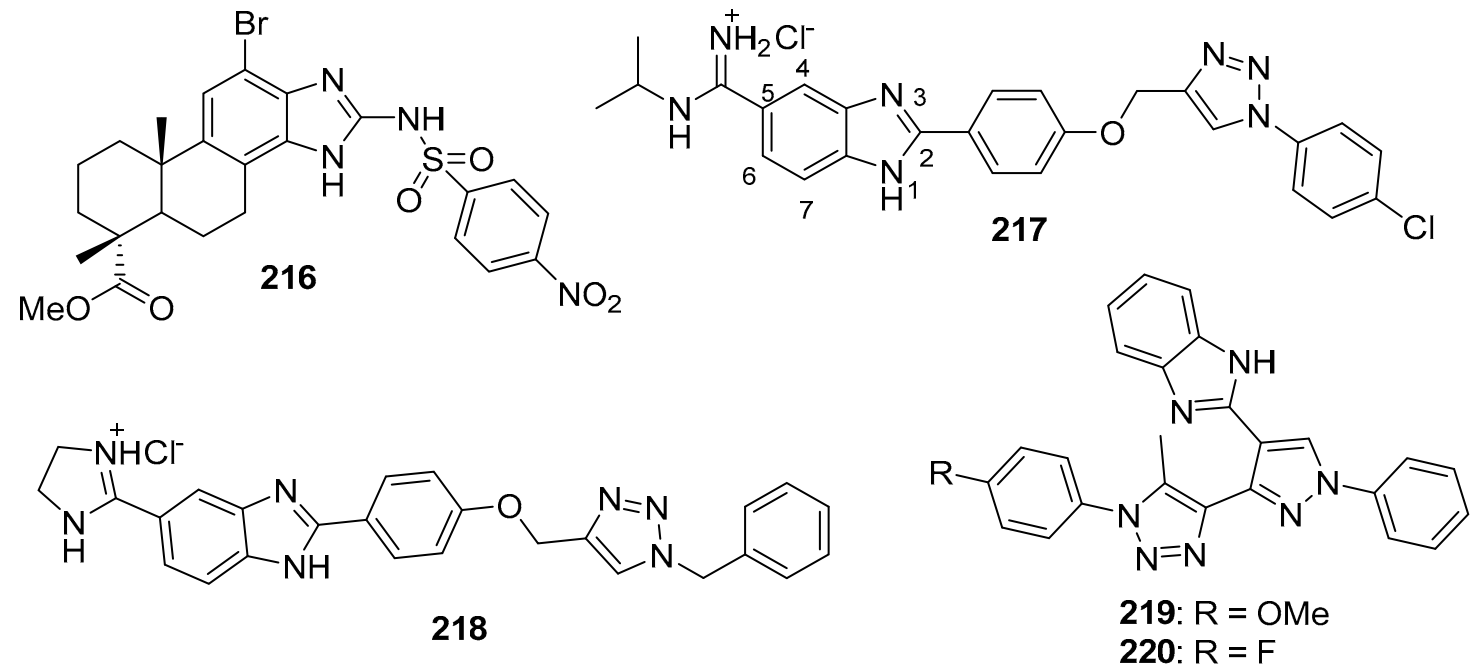

Figure 18. Benzimidazole containing and related molecules with anticancer activity (compounds 200-220). 
Novel N1, C2-substituted benzimidazoles were synthesized by Mohareb et al. and screened against A549, H460, HT29, MKN-45, U87MG, and SMMC-7721 cancer cell lines [180]. The most potent compounds in this series exhibited $\mathrm{IC}_{50}$ values in the range between $0.2-4.0 \mu \mathrm{M}$ against all cancer cell lines tested, while compounds 202-206 were non-toxic when tested against shrimp larvae. In terms of the SAR, compounds containing hydrazine (202) or nitrile (203) at the R group possessed enhanced activity compared to the corresponding chlorine-containing derivative. The presence of $-\mathrm{COCH}_{3}$ and $-\mathrm{COOC}_{2} \mathrm{H}_{5}$ in compound 204 resulted in increased antiproliferative effects, while, among coumarin compounds, placement of 2,4-dichloro and 4-nitro substitutions on the phenyl substituent resulted in high anticancer activity on all the cancer cell lines tested.

Chouiter et al. synthesized chalcones and pyrazoline-type compounds based on an imidazole or benzimidazole core and evaluated the anticancer activity of these compounds against A549 adenocarcinoma and AGS stomach cancer cell lines; counter-screening was also performed against the MRC-5 human lung fibroblast cell line [181]. The target compounds were more potent against AGS cells. Compounds 207, 208, and 209 displayed $\mathrm{IC}_{50}$ values of 20.9, 29.3, and $15.1 \mu \mathrm{M}$ against the AGS cell line and $\mathrm{IC}_{50}$ values of $67.1,>100$, and $45.9 \mu \mathrm{M}$ against the MRC- 5 cell line. Compounds containing pyrazoline in place of the $\alpha, \beta$-unsaturated ketone linker (such as compound 210) were inactive on all the three cancer cell lines tested. Increased caspase-3 activity was observed in A549 and AGS cells exposed to compounds 207-209.

A series of benzimidazole-chalcone hybrids synthesized by Hsieh et al. were screened for anticancer activity against A549, MCF-7, HepG2, and OVCAR-3 cancer cell lines [182]. Compounds 211-213 were active on all four cell lines tested, with $\mathrm{IC}_{50}$ values $<15 \mu \mathrm{M}$. Among these, compound 213 displayed the greatest antiproliferative activity with $\mathrm{IC}_{50}$ values of 10.93, 9.73, 8.91, and $10.76 \mu \mathrm{M}$ against HepG2, A549, MCF-7, and OVCAR-3 cells, respectively. Analysis of the SAR indicated that the presence of 5- or 6-membered nitrogen-containing heterocycles linked at the $N 1$ position of benzimidazole by an alkyl chain increased potency.

Suk et al. evaluated the activity of benzimidazole derivative 211 against sorafenib resistant HCC cell lines (Hep3B-SR and HuH7-SR) [183]. Compound 211 displayed significant antiproliferative effects against these two cell lines at a concentration of $25 \mu \mathrm{M}$. Western blotting studies revealed that, at a concentration of $15 \mu \mathrm{M}$, compound 211 inhibited p70S6, AKT, and STAT3 phosphorylation in these cells. The treatment of these cells with $15 \mu \mathrm{M}$ compound 211 resulted in enhanced cleavage of PARP, as well as decreased expression of Fas, at the cell surface. When compound 211 was given at $4 \mathrm{mg} / \mathrm{kg} /$ day by i.p. injection, moderate tumor growth inhibition was observed in a sorafenib resistant murine xenograft model of HCC. Immunostaining revealed that mice treated with compound $\mathbf{2 1 1}$ displayed lower nuclear levels of Ki-67 and PCNA compared to control mice. Moreover, sorafenib resistant tumors from mice treated with compound $\mathbf{2 1 1}$ displayed lower levels of cyclin D1 and HCC biomarkers compared to tumors from mice that received vehicle.

Rasal et al. synthesized compounds containing a dimethylpyrrole carboxamidebenzimidazole scaffold as potential anticancer agents that were evaluated against the NCI 60 cancer cell line panel [184]. When tested at a concentration of $10 \mu \mathrm{M}$, compound 214 displayed the highest growth inhibition of $62.46 \%$ against the MDA-MB- 435 and $40.24 \%$ against the MDA-MB-468 cell lines. In terms of the SAR, compounds bearing acyclic aliphatic amines in an amide linkage at the $\mathrm{C} 3$ position of pyrrole lacked potent anticancer activity. Introduction of imidazole or pyrazole at this position did not improve activity, while insertion of tetrahydrothienopyridine (compound 215) has a positive influence on activity against T47D and MDA-MB-468 breast cancer cell lines.

The cytotoxic and apoptosis-inducing activity of benzimidazole derivatives of dehydroabietic acid (100; see Figure 9) were evaluated against MCF-7, HeLa, and HepG2 cancer cell lines and a normal hepatocyte (LO2) cell line by Li et al. [185]. Among these compounds, 216 displayed the highest activity with $\mathrm{IC}_{50}$ values of $0.87,9.39$, and 8.31 against MCF-7, HeLa, and HepG2 cell lines, respectively. This compound also displayed 
an $\mathrm{IC}_{50}$ value of $42.83 \mu \mathrm{M}$ on the $\mathrm{LO} 2$ cell line, thus showing selectivity towards the cancer cell lines. The SAR indicated that compounds bearing electron-withdrawing groups on the phenylsulfonamide portion displayed stronger activity when compared to electrondonating groups. Moreover, sulfonamide derivatives displayed higher activities compared to amide derivatives. Incubation of MCF-7 cells with 1-4 $\mu \mathrm{M}$ concentrations of compound 216 caused a dose-dependent accumulation of cells in the S-phase of the cell cycle, as well as a dose-dependent increase in apoptotic cells.

Novel amidino substituted benzimidazoles linked to 1,2,3-triazole via a phenoxy methyl or ethyl linker were synthesized using microwave and ultrasound irradiation by Bistrovic et al. [186]. The antiproliferative activities of these compounds were evaluated against A549, CFPAC-1, HeLa, and SW620 cell lines, as well as on normal human lung fibroblasts (WI38). These compounds were highly selective towards the A549 cell line, with compounds 217 and 218 exhibiting high potency ( $\mathrm{IC}_{50}$ values of 0.05 and $0.07 \mu \mathrm{M}$, respectively) and comparatively little effect on W138 fibroblasts ( $\mathrm{IC}_{50}$ values of 8.04 and $6.89 \mu \mathrm{M}$, respectively). In terms of the SAR, compounds containing isopropyl amidine and imidazoline at the C5-position of benzimidazole were more active and selective towards the A549 cell line, while compounds possessing a phenoxymethyl group at the $\mathrm{C} 2$ position of benzimidazole also displayed potent activity against this cell line. A significant reduction in PDE5, CDK9/cyclin T1, TGM2, phospho SK1, phospho p38 MAPK, and phospho-p53 levels were observed in A549 cells treated with a $0.14-\mu \mathrm{M}$ concentration of compound 218. Compound 217 at a concentration of $0.10 \mu \mathrm{M}$ did not affect PDE5, CDK9/cyclin T1, TGM2, or phospho-p53 levels but displayed similar (albeit weaker) effects on phospho SK1 and phospho p38 MAPK levels in A549 cells.

Ashok et al. prepared 1,2,3-triazole-based pyrazole-benzimidazole derivatives through conventional, as well as microwave-assisted, synthesis and evaluated their in vitro antiproliferative activity against C6 and MCF-7 cell lines [187]. These derivatives were obtained in higher yields using microwave-assisted synthesis (77-89\%) compared to conventional heating in DMF (57-66\%). Compound 219 displayed an $\mathrm{IC}_{50}$ value of $0.102 \mu \mathrm{M}$ against the $\mathrm{C} 6$ cell line, while the standard drug cisplatin exhibited an $\mathrm{IC}_{50}$ value of $0.122 \mu \mathrm{M}$. Compounds 219 and 220 displayed $\mathrm{IC}_{50}$ values of 0.110 and $0.144 \mu \mathrm{M}$ against the MCF-7 cell line, while the $\mathrm{IC}_{50}$ value for cisplatin against these cells was $0.596 \mu \mathrm{M}$.

\subsection{Imidazopyridines, Imidazopyrimidines, and Related Compounds}

A series of imidazole and imidazopyridine dimers synthesized by Meenakshisundaram et al. was tested for cytotoxicity against HeLa, MDA-MB-231, and ACHN cancer cell lines [188]. Compounds 221 and 222 (see Figure 19 for structures 221-237) displayed $\mathrm{GI}_{50}$ values of $0.43 \mu \mathrm{M}$ and $0.30 \mu \mathrm{M}$, respectively, against the MDA-MB-231 cell line, showing higher potency than the standard drug adriamycin $\left(\mathrm{GI}_{50}=0.51 \mu \mathrm{M}\right)$. In addition, administration of $\mathbf{2 2 1}$ and 222 (both given at $50 \mathrm{mg} / \mathrm{kg}$ for 14 days by gastric intubation) in a 7,12-dimethylbenz[ $a]$ anthracene-induced rat mammary carcinoma model caused a reduction of cancer markers (carcinoembryonic antigen and cancer antigen 15-3) and resulted in lower levels of the liver enzymes aspartate aminotransferase, alanine aminotransferase, and alkaline phosphatase compared to rats in the mammary carcinoma control group. In terms of the SAR for these compounds, imidazopyridine dimers were more active compared to imidazole dimers.

Güçlü et al. developed a novel method for the synthesis of imidazopyridine derivatives by reacting 4-substituted- $N$-propargyl biaryl ketones (scaffold 223) with 4-methylpiperidine under microwave irradiation [189]. The derivatives were screened for activity against the LN-405 glioblastoma cell line and normal skin fibroblasts (WS-1). Compound 224 was the most potent analog against the $\mathrm{LN}-405$ cell line, displaying an $\mathrm{IC}_{50}$ value of $10 \mu \mathrm{M}$, while compound 225 exhibited an $\mathrm{IC}_{50}$ value of $75 \mu \mathrm{M}$ against this cell line. Compound 224 was selectively cytotoxic for the LN-405 cell line compared to the fibroblast cells $\left(\mathrm{IC}_{50}=480 \mu \mathrm{M}\right)$. Results from a comet assay in LN-405 cells treated with a $10 \mu \mathrm{M}$ compound 224 showed that this derivative caused DNA damage (affecting $14 \%$ of the cells) compared to the control 
(where DNA damage was observed in $0.7 \%$ of the cells). In silico studies using Schrödinger suggested that the target compounds are likely to be orally available and should penetrate the blood-brain barrier.<smiles>c1ccc(Cc2c(-c3ccc(-c4nc5ccccn5c4Cc4ccccc4)cc3)nc3ccccn23)cc1</smiles>

221<smiles>[R][R]#[R20]#[PH]F</smiles>

228<smiles>c1ccc(Cc2c(-c3cccc(-c4nc5ccccn5c4Cc4ccccc4)c3)nc3ccccn23)cc1</smiles>

222<smiles>[R]C(=O)c1nc([R])cn1CC#C</smiles>

223: $R=$ aryl<smiles>[R]c1ccc(-c2cncc(N3CCC(C)CC3)c2)cc1</smiles><smiles>[R]c1ccc(/C=C/c2nc3cc([R])c([R2])cn3c2NC2CCCCC2)cc1</smiles>

226: $R^{1}=M e, R^{2}=R^{3}=H$ 227: $R^{1}=H, R^{2}=M e, R^{3}=O M e$<smiles></smiles>

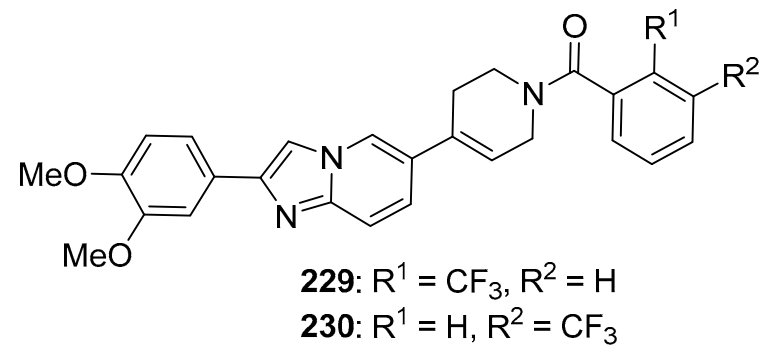<smiles>COc1cccc(CN2CCCN(c3ccn4cc(-c5ccc(F)cc5)nc4n3)CC2)c1</smiles><smiles>COc1ccc(-n2nc(-c3cn(C)cn3)cc2N)cc1</smiles>
$\begin{gathered}\text { "active methylene" } \\ \text { compounds }\end{gathered}$
$\underset{\mathrm{MW}, 15-25 \text { min }}{\mathrm{CH}_{3} \mathrm{COOH}}$

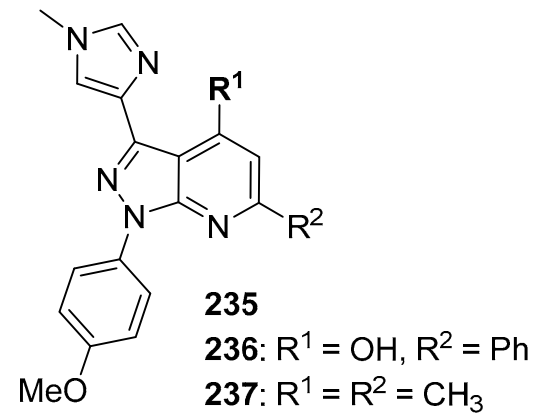

Figure 19. Imidazopyridines, imidazopyrimidines, and related compounds with anticancer activity (compounds 221, 222, 224-233, 236, and 237). Reagents/reagent scaffolds $(223,234)$ and target compound scaffold 235 from reactions described in the text are also shown. 
Khalili et al. synthesized a library of styrylimidazopyridines and evaluated them for activity against three breast cancer cell lines [190]. Compound 226 displayed $\mathrm{IC}_{50}$ values of 9.59, 12.12, and $10.10 \mu \mathrm{M}$ against MDA-MB-231, MCF-7, and T47D cell lines, respectively, while compound 227 displayed $\mathrm{IC}_{50}$ values of 8.13 and $9.61 \mu \mathrm{M}$ against MCF-7 and T47D cell lines. In general, compounds synthesized from cyclohexyl isocyanides had higher potencies than derivatives synthesized from tert-butyl isocyanides. The placement of a methyl group at positions 5, 6, or 7 of the imidazopyridine core increased the anticancer activity of compounds obtained from cyclohexyl isocyanides, while insertion of chlorine at C6 caused the loss of activity against all three cell lines.

Chitti et al. reported the synthesis of imidazopyridine analogs as potential antiproliferative agents against A549, HeLa, and B16F10 cancer cell lines and also performed counter-screening using the HEK-293 cell line [191]. A subset of the synthesized compounds displayed antiproliferative activity in the range between $2.55-20.0 \mu \mathrm{M}$ against the tested cancer cell lines, with compounds 228-230 exhibiting $\mathrm{IC}_{50}$ values in the range between 2.55-8.11 $\mu \mathrm{M}$ against these cancer cell lines. Among these, 229 and 230 were the most potent against the $\mathrm{A} 549$ cell line, displaying $\mathrm{IC}_{50}$ values of 2.55 and $3.69 \mu \mathrm{M}$ against this cell line, respectively. In terms of the SAR, imidazopyridines possessing amide functionalities were more potent compared to derivatives containing a sulfonamide moiety.

A series of imidazopyridine-arylaminopropenone conjugates synthesized by Mani et al. were tested for activity against A549, HCT116, B16F10, BT474, and MDA-MB-231 cancer cell lines [192]. Among these compounds, 231 displayed the greatest potency against the HCT116 cell line $\left(\mathrm{IC}_{50}=1.21 \mu \mathrm{M}\right)$. While the structure-activity relationship is complex, the inclusion of an electron withdrawing group on the C3 phenyl group and on the terminal aniline generally resulted in increased potency. Compound 231 caused a dosedependent increase in the percentage of HCT116 cells in the $G_{0} / G_{1}$ phase of the cell cycle at concentrations of $0.5-2.5 \mu \mathrm{M}$ and increased the formation of reactive oxygen species in these cells at 1.0 and $2.5 \mu \mathrm{M}$ concentrations.

Mantipally et al. synthesized a series of novel homopiperazine linked imidazopyrimidine derivatives as candidate cytotoxic and antimicrobial agents [193]. Evaluation of these compounds against a panel of four human cancer cell lines (SKOV3, DU-145, HeLa, and A549) revealed that compound 232 displayed an $\mathrm{IC}_{50}$ value of $5.98 \mu \mathrm{M}$ against $\mathrm{A} 549$ cells, while compound 233 exhibited $\mathrm{IC}_{50}$ values of $6.24 \mu \mathrm{M}, 6.54 \mu \mathrm{M}$, and $4.14 \mu \mathrm{M}$ on DU-145, HeLa, and A549 cell lines, respectively. Compounds bearing an amide group on the diazepane nitrogen were generally more active when compared to analogs bearing a sulfonamide moiety at this position.

El-Borai et al. synthesized imidazolyl pyrazolopyridine derivatives (scaffold 235) from 1-(4-methoxyphenyl)-3-(1-methyl-1H-imidazol-4-yl)- $1 H$-pyrazol-5-amine (234) and "active methylene" compounds, such as ethyl benzoylacetate and pentane-2,4-dione, using microwave irradiation [194]. Comparing conventional heating to microwave irradiation, the microwave reaction occurred in high yields (81-92\%) in just $15-25 \mathrm{~min}$, while yields were lower $(65-76 \%)$ and reaction times were longer $(4-8 \mathrm{~h})$ using conventional heating. Target compounds were tested for antiproliferative activity against the MCF-7 cancer cell line, with $\mathrm{IC}_{50}$ values in a narrow range $(16.6-19.3 \mu \mathrm{g} / \mathrm{mL})$. Compounds 236 and 237 displayed $\mathrm{IC}_{50}$ values of 16.6 and $18.1 \mu \mathrm{g} / \mathrm{mL}$, respectively.

\subsection{Naphthoquinone Imidazoles}

Liu et al. synthesized morpholino ethyl-substituted naphthoquinone imidazoles that were tested for in vitro activity against MCF-7, HeLa, and A549 cell lines, as well as for their effects on the L929 normal mouse fibroblast cell line [195]. Compound 238 (see Figure 20 for structures of compounds 238-241) displayed $\mathrm{IC}_{50}$ values of $4.3,10.6$, and $8.3 \mu \mathrm{M}$ against A549, MCF-7, and HeLa cells, respectively, while exhibiting an $\mathrm{IC}_{50}$ value of $67.3 \mu \mathrm{M}$ against the L929 cell line. In terms of the SAR, 2-alkyl-substituted compounds were less potent compared to 2-aryl-substituted compounds. In addition, compounds lacking a quinone moiety were inactive on the cancer cell lines tested. 
<smiles>COc1ccc(-c2nc3c(n2CCN2CCOCC2)C(=O)c2ccccc2C3=O)cc1Cl</smiles><smiles>CC[n+]1c2c(n(C(C)C)c1/C=C/c1ccc(C)cc1)C(=O)c1ccccc1C2=O</smiles><smiles>COCC[n+]1c2c(n(Cc3ccccc3)c1/C=C/c1ccc(O)c(OC)c1)C(=O)c1ccccc1C2=O</smiles>

240<smiles>COCC[n+]1c2c(n(Cc3ccccc3)c1/C=C/c1c[nH]c3ccccc13)C(=O)c1ccccc1C2=O</smiles>

241

Figure 20. Naphthoquinone imidazoles with anticancer activity (compounds 238-241).

Wei et al. synthesized a novel series of arylvinyl-naphthoimidazolium iodide and bromide derivatives and screened these compounds for antiproliferative activity against PC-3, HeLa, and A375 cell lines [196]. Compounds 239 and 240 displayed IC $_{50}$ values of $0.022,1.12,1.07 \mu \mathrm{M}$ and $0.022,1.13$, and $0.536 \mu \mathrm{M}$ against PC-3, HeLa, and A375 cells, respectively, while indole-substituted compound 241 displayed $\mathrm{IC}_{50}$ values of $0.128,0.059$, and $0.212 \mu \mathrm{M}$ against these cell lines, respectively. In general, phenyl vinyl substitutions at the $\mathrm{C} 2$ position of imidazole resulted in compounds that were more active against PC-3 cells; however, compounds bearing indole vinyl substituents were more active towards A375 and HeLa cell lines. In A375 cells, both compounds 239 and 241 decreased the expression of survivin and Bcl-2 and increased the percentage of annexin V positive cells at $1 \mu \mathrm{M}$ concentrations. In a subcutaneous solid tumor model using Ehrlich's ascites carcinoma cells, intraperitoneal administration of compound 241 at a dose of $0.6 \mathrm{mg} / \mathrm{kg} / \mathrm{day}$ for 10 consecutive days resulted in $53.12 \%$ reduction in tumor progression compared to the vehicle control group.

\subsection{Polysubstituted Imidazole Derivatives}

Hebishy et al. reported the preparation of bis- and poly(imidazoles) via a threecomponent reaction among 1,2-diketones, aldehydes, and ammonium acetate using $10 \mathrm{~mol} \%$ of a $\mathrm{ZnO}$ nanocatalyst under conventional heating, as well as microwave irradiation [197]. The target compounds were tested against HepG2, MCF-7, and Caco-2 cancer cell lines and were counter-screened using Vero (African green monkey kidney) cells. Among these target compounds, 242, 243, and 244 (see Figure 21 for structures of compounds 242-253) exhibited $\mathrm{IC}_{50}$ values against HepG2 cells of $8.14,9.58$, and $9.77 \mu \mathrm{M}$, respectively, while all other compounds displayed $\mathrm{IC}_{50}$ values greater than $10 \mu \mathrm{M}$. Compounds 242 and 244 displayed selectivity indexes of 27.47 and 13.62 against HepG2 cells compared to Vero cells.

Ghanbarimasir et al. synthesized and evaluated the activity of 2-aminoimidazolequinoxaline hybrids against MCF-7 and HCT116 cancer cell lines, along with their effects on a normal HFF cell line [198]. The most potent activity was exhibited by compounds 245 and 246. Compound 245 displayed 83.3\% inhibition against MCF-7 cells and compound 246 exhibited $77.3 \%$ growth inhibition against HCT116 cells when tested at a concentration of $50 \mu \mathrm{g} / \mathrm{mL}$. The standard drug doxorubicin exhibited $93.3 \%$ and $97.2 \%$ inhibition against 
these cell lines, respectively, when tested at the same concentration. Unsubstituted quinoxaline compound 245 displayed the best activity; substitution of the phenyl group linked to the imidazole ring in compound $\mathbf{2 4 5}$ with electron-withdrawing or electron-releasing groups led to a decrease in potency. Among the 6-Cl and 7-Cl-quinoxaline series, the 4-methoxyphenyl substitution in the former series showed the highest potency against both cancer cell lines tested.<smiles>c1coc(-c2nc(-c3ccc(OCCCOc4ccc(-c5nc(-c6ccco6)c(-c6ccco6)[nH]5)cc4)cc3)[nH]c2-c2ccco2)c1</smiles><smiles>[R14][H]</smiles><smiles>[R4]c1ccc(-c2nc(-c3ccccc3)c(-c3ccccc3)[nH]2)cc1COc1ccc(-c2nc(-c3ccccc3)c(-c3ccccc3)[nH]2)cc1</smiles>

<smiles>[R]c1cc([R])c(/C=N/Nc2nc(O)c(-c3ccccc3)[nH]2)c([R])c1</smiles>

247: $R^{1}=F, R^{2}=H, R^{3}=C l$ 248: $\mathrm{R}^{1}=\mathrm{H}, \mathrm{R}^{2}=\mathrm{Cl}, \mathrm{R}^{3}=\mathrm{Cl}$<smiles>[R]c1ccc(NC(=O)c2cnn3c(NC(C)(C)CC(C)(C)C)c(C(C)(C)C)[nH]c23)cc1</smiles>

249: $R=F$ 250: $\mathrm{R}=\left(\mathrm{CH}_{3}\right)_{2} \mathrm{~N}$<smiles>[R]c1ccc(-c2nc3sc4cc(OC)ccc4n3c2C(=O)/C=C\Nc2ccc3[nH]ccc3c2)cc1</smiles><smiles>[R16]N/C=C\C(=O)c1c(-c2ccc([R])cc2)nc2sc3cc(OC)ccc3n12</smiles>

251: $\mathrm{R}=\mathrm{H}$

252: $R=F$

Figure 21. Polysubstituted imidazole derivatives with anticancer activity (compounds 242-253).

The anticancer activity of imidazole derivatives prepared from guanylhydrazone and phenylglyoxal was evaluated in vitro against MCF-7 and HepG2 cancer cell lines by Yavuz et al. [199]. The synthesized compounds displayed selectivity towards MCF-7 cells compared to HepG2 cells. The most potent compounds in this series (247 and 248) exhibited IC 50 values against MCF-7 cells of 10.22 and $14.80 \mu \mathrm{M}$, respectively. Compounds 
substituted with electron-withdrawing groups as in 247 and 248 were more potent than compounds bearing electron-releasing groups.

Demjén et al. synthesized a library of imidazopyrazole-7-carboxamides and measured their activity against 4T1, MCF-7, and HL-60 cancer cell lines [200]. Compounds 249 and 250 displayed the greatest potency against the HL-60 cancer cell line, with $\mathrm{IC}_{50}$ values of 0.183 and $0.297 \mu \mathrm{M}$, respectively. Regarding substitution on the imidazopyrazole system, compounds having alkyl substitutions at C2 and alkylamines at C3 displayed the highest potency.

Shaik et al. reported the synthesis of benzoimidazothiazole-propenone conjugates as potential antiproliferative agents against HeLa, HepG2, A549, and MCF-7 cancer cell lines [201]. Compounds 251 and 252 displayed $\mathrm{IC}_{50}$ values ranging from 1.6-8.4 $\mu \mathrm{M}$ against the four cancer cell lines tested. Compound 251 showed the greatest potency against the HeLa cell line with an $\mathrm{IC}_{50}$ value of $1.6 \mu \mathrm{M}$. In terms of the SAR for these molecules, compounds possessing heteroaryl groups at $\mathrm{R}^{1}$ in scaffold 253 displayed superior potency compared to compounds possessing aryl rings at this position, while compounds displaying a chlorine at $\mathrm{R}^{2}$ generally exhibited inferior potency compared to compounds with a hydrogen atom at this position. Treatment of HeLa cells with compound 251 at a concentration of $5 \mu \mathrm{M}$ caused a $40 \%$ decrease in the mitochondrial membrane potential and a 4 -fold increase in the level of reactive oxygen species.

\subsection{Natural Product Imidazole Derivatives}

Hu et al. synthesized a series of artemisinin-imidazole and artemisinin-indole hybrids which were tested in vitro against A549, MCF-7, HepG2, and MDA-MB-231 cancer cell lines and were counter-screened against a normal LO2 cell line [202]. Most of the artemisininimidazole and artemisinin-indole hybrids showed good potency $\left(\mathrm{IC}_{50}\right.$ values below $\left.20 \mu \mathrm{M}\right)$ on MCF-7 and A549 cell lines when compared to artemisinin and dihydroartimisinin ( $\mathrm{IC}_{50}$ values ranging from 34-51 $\mu \mathrm{M}$ against these cell lines). Artemisinin-imidazole hybrid compound 254 (see Figure 22 for structures 254-265) exhibited an $\mathrm{IC}_{50}$ value of $9.78 \mu \mathrm{M}$ against MCF-7 cells, while artemisinin-indole hybrid 255 displayed $\mathrm{IC}_{50}$ values of 5.25 and $6.17 \mu \mathrm{M}$ on MCF-7 and A549 cell lines, respectively. In general, derivatives bearing an indole substitution instead of imidazole displayed slightly greater potency. Compound 255 showed outstanding reversal activity in MCF-7/ADR cells resistant to adriamycin, displaying a reversal fold of 117.

Based on the strong antitumor activity of the natural product neoplanocin A (256) and the related cyclopentenyl nucleoside 258, a series of fluorocyclopentenyl pyrimidines and purines were synthesized and tested against six cancer cell lines [203]. Among the pyrimidine derivatives, 258 was the most active against these cell lines (A549, HCT-116, SNU-638, MDA-MB-231, SK-Hep-1, and PC-3), with $\mathrm{IC}_{50}$ values ranging from $0.18-0.76 \mu \mathrm{M}$, while the addition of a fluorine atom at the 5-position of the pyrimidine ring resulted in a significant loss of potency. For the purines, fluorocyclopentenyl analog 257 ( $\mathrm{IC}_{50}$ values $1.10-2.17 \mu \mathrm{M})$ and its N6-methyl derivative $\left(\mathrm{IC}_{50}\right.$ values $\left.2.14-15.3 \mu \mathrm{M}\right)$ displayed potency against the six cancer cell lines similar to or slightly lower than neoplanocin $\mathrm{A}$ ( $\mathrm{IC}_{50}$ values 0.82-2.36 $\mu \mathrm{M})$, but the corresponding derivative bearing an oxygen atom bound at C6 lacked activity. Addition of the bulkier cyclopropylmethyl group to the N6 amino group resulted in a loss of activity, as did addition of an amino group to $C 2$ of the purine ring. The phosphoamidate prodrug of compound 257 was 1.6- to 17.7-fold less active than 257 itself against the cancer cell lines, leading the authors to speculate that anticancer action is through inhibition of S-adenosylhomocysteine hydrolase by 257 rather than interference with DNA or RNA polymerase by the triphosphorylated metabolite of 257. 

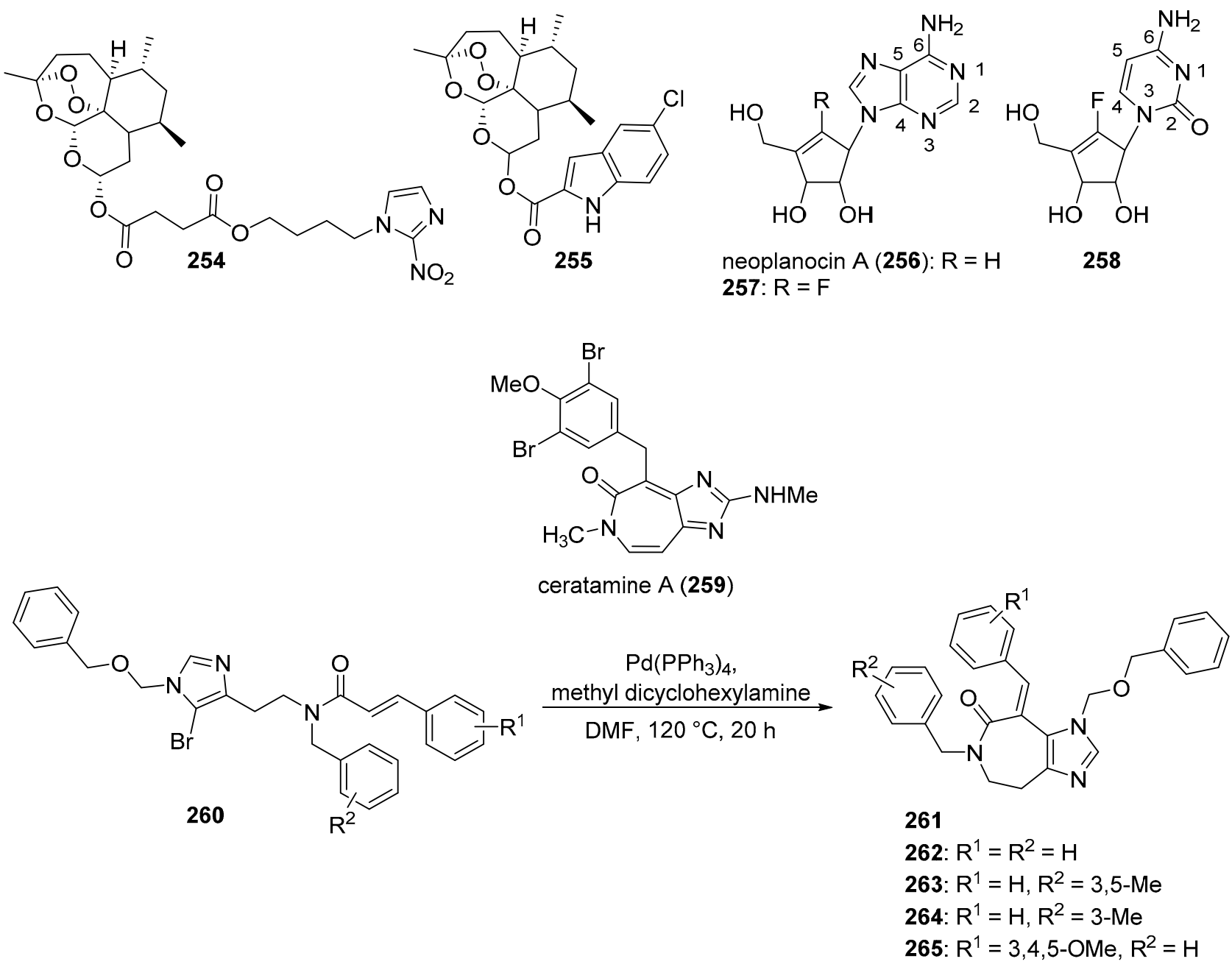

Figure 22. Natural product imidazole derivatives displaying anticancer activity (compounds 254-259 and 262-265). Reagent scaffold 260 and target compound scaffold 261 are also shown.

A novel series of imidazoazepine derivatives inspired by the natural product ceratamine A (259) was synthesized by Pan et al. [204]. The key step in the synthesis was the formation of the imidazoazepine core (scaffold 261) via an intramolecular Heck reaction starting from 260. The target compounds were tested for activity against the BGC-823, A549, HCT116, HepG2, and A2780 cancer cell lines. Derivatives 262, 263, and 264 displayed $\mathrm{IC}_{50}$ values of $20.0,6.23$, and $3.80 \mu \mathrm{M}$ against the HCT116 cancer cell line, whereas the $\mathrm{IC}_{50}$ value of ceratamine A was $12.4 \mu \mathrm{M}$. Interestingly, compounds with substitutions possessing bulky groups, electron-withdrawing groups, or electron-donating groups on the benzyl substituent attached to the nitrogen atom of the azepine ring generally displayed decreased potency against the other four cell lines tested. Compound 265, which contains a 3,4,5-trimethoxyphenyl substitution corresponding to the 3,5-dibromo-4-methoxyphenyl group of 259, was active against all five cancer cell lines tested, with $\mathrm{IC}_{50}$ values ranging from 8.56-12.9 $\mu \mathrm{M}$. The removal of the benzyloxymethyl group from the imidazole ring resulted in a dramatic loss of potency against the cell lines.

\subsection{Purine Derivatives}

Tuncbilek et al. synthesized $\beta$-D-ribofuranosyl-purine derivatives that were evaluated for anticancer activity against Huh7, HCT116, and MCF-7 cell lines [205]. Of these compounds, 266 (see Figure 23 for structures of compounds 266-283) displayed the greatest activity, with $\mathrm{IC}_{50}$ values of 2,1 , and $4 \mu \mathrm{M}$ against the three cell lines, respectively. By comparison, the standard drug 5-FU exhibited $\mathrm{IC}_{50}$ values of 30,4 , and $3 \mu \mathrm{M}$ against 
the Huh7, HCT116, and MCF-7 cell lines. Compound 266 also displayed activity against HepG2, MAHLAVU, and FOCUS hepatocellular carcinoma cells ( $\mathrm{IC}_{50}$ values of 3, 3, and $1 \mu \mathrm{M}$, respectively), while 5-FU exhibited $\mathrm{IC}_{50}$ values of 5,10 , and $4 \mu \mathrm{M}$ against these three hepatocellular carcinoma cell lines, respectively.<smiles>OCC1OC(n2cnc3c(N4CCN(c5ccc(C(F)(F)F)cc5)CC4)nc(Cl)nc32)C(O)C1O</smiles><smiles>CC(O)Cn1cnc2c1c(=O)n(C)c(=O)n2C[C@H](O)[C@H](O)Cn1cnc2c1c(=O)n(C)c(=O)n2CC(C)OCc1cn(CCCn2cnc3c(Br)c(Br)c(Br)c(Br)c32)nn1</smiles><smiles>CC(Cn1cnc2c1c(=O)n(C)c(=O)n2C)OCc1cn(CCCn2nc3c(Br)c(Br)c(Br)c(Br)c3n2)nn1</smiles><smiles>CC(CN1c2ccccc2Sc2ccccc21)OC(=O)OC(C)Cn1cnc2c1c(=O)n(C)c(=O)n2C</smiles><smiles>C#CCSc1nc(SCC#C)c2c(ncn2C)n1</smiles><smiles>CCCSc1nc(Cl)c2c(n1)N(Cc1ccccc1)C(C(=O)N1CCN(C)CC1)N2</smiles><smiles>[Z20]c1nc(SC)nc2c1NC(C(=O)N1CCN(C)CC1)N2Cc1cccs1</smiles><smiles>CCn1c(N/N=C/c2cn(-c3ccccc3)nc2-c2ccc(Cl)cc2)nc2c1c(=O)n(C)c(=O)n2C</smiles>

275<smiles>CCn1c2c(=O)n(C)c(=O)n(C)c2n2c(-c3cn(-c4ccccc4)nc3-c3ccc(Cl)cc3)nnc12</smiles><smiles>[R]c1ccc(N2CCN(c3nc(Cl)nc4c3ncn4C3CCCC3)CC2)cc1</smiles><smiles>FC(F)(F)c1ccc(N2CCN(c3nc(Cl)nc4c3ncn4C3CCCC3)CC2)nc1</smiles><smiles>[R17][R](=[R]([H])F)[R](F)=C1c2nc(CC)n(-c3cc(OCC#C)c(Cl)cc3F)c(=O)c2N=C(C)N1Cc1ccc([R])cc1[R]</smiles><smiles>C#CCOc1cc(-n2cnc3c(nc(C)n3Cc3ccc(F)cc3F)c2=O)c(F)cc1Cl</smiles>

282

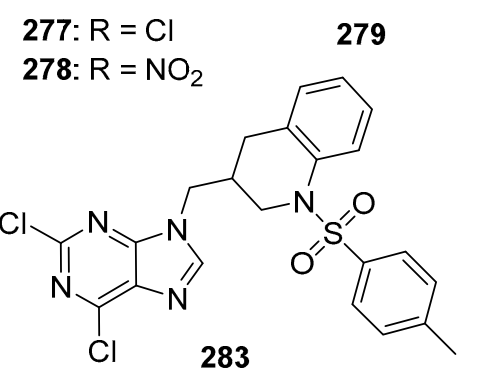

Figure 23. Purine derivatives with anticancer activity (compounds 266-283). 
Borowiecki et al. synthesized analogs of proxyphylline (267) and tested them for activity against CCRF-CEM and MCF-7 cancer cell lines [206]. Of the target compounds, polybrominated derivatives $\mathbf{2 6 8}$ and $\mathbf{2 6 9}$ displayed the greatest potency against CCRF-CEM cells, with $\mathrm{EC}_{50}$ values of 6.3 and $6.5 \mu \mathrm{M}$, respectively. Against MCF-7 cells, the greatest potency was observed for compounds 270 and 269, which both exhibited $\mathrm{EC}_{50}$ values of $80 \mu \mathrm{M}$ against this cancer cell line. By comparison, doxorubicin displayed an $\mathrm{EC}_{50}$ value of $1.4 \mu \mathrm{M}$ against both CCRF-CEM and MCF-7 cells. These proxyphylline analogs were also tested for antifungal activity against Candida albicans, with compounds $\mathbf{2 7 0}$ and 269 exhibiting the best antifungal activity.

Kowalska et al. tested the anticancer activity of multisubstituted purine and xanthine derivatives against SNB-19, MDA-MB-231, and C32 cell lines and also counter-screened these compounds against normal HFF-1 cells [207]. The target compounds possessed a range of activities against the four cell lines tested. Compound 271 was highly active against SNB-19 cells, possessing an $\mathrm{IC}_{50}$ value of $0.07 \mu \mathrm{g} / \mathrm{mL}$ against this cell line with a selectivity index of 287 when compared to HFF-1 cells. Compound 272 displayed good potency against MDA-MB-231 cells, possessing an $\mathrm{IC}_{50}$ value of $1.00 \mu \mathrm{g} / \mathrm{mL}$ against this cell line with a selectivity index of 10 when compared to HFF-1 cells.

Zhao et al. synthesized 6-chloro-2-propylthio-8,9-dihydro-7H-purine derivatives as potential antiproliferative agents and evaluated their activity against A549, MGC-803, PC-3 and TE- 1 cell lines [208]. Of the target compounds synthesized, 273 and 274 displayed the greatest activity against $\mathrm{A} 549$ cells, exhibiting $\mathrm{IC}_{50}$ values of 2.80 and $6.42 \mu \mathrm{M}$, respectively. Compound 274 displayed an $\mathrm{IC}_{50}$ value of $5.02 \mu \mathrm{M}$ against PC-3 cells. For comparison, the standard drug 5-FU displayed $\mathrm{IC}_{50}$ values of 13.18 and $12.33 \mu \mathrm{M}$ against A549 and PC-3 cells, respectively. When compound 273 was counter-screened against normal GES-1 cells, an IC 50 value of $303 \mu \mathrm{M}$ was obtained. Upregulation of E-cadherin (a biomarker of epithelial cells) and down-regulation of N-cadherin and vimentin (biomarkers of mesenchymal cells) was observed in A549 cells incubated with compound $\mathbf{2 7 3}$ at concentrations ranging from 0.5-2.0 $\mu \mathrm{M}$. Dose-dependent inhibition of the migration of A549 cells was observed in a wound healing assay when compound $\mathbf{2 7 3}$ was incubated with these cells at concentrations ranging from $0.25-1.0 \mu \mathrm{M}$.

Shaaban et al. synthesized purines containing a pyrazole group as potential anticancer agents against A549, MCF-7, HepG2, Caco-2, and PC-3 cancer cells [209]. Counter-screening was performed against the HPBMC cell line. Compounds 275 and 276 displayed the lowest $\mathrm{IC}_{50}$ values (18.89 and $79.65 \mu \mathrm{M}$, respectively) against the A549 cell line (the $\mathrm{IC}_{50}$ of 5-FU was $83.03 \mu \mathrm{M}$ ); compound 275 exhibited a selectivity index of 32 and compound 276 displayed a selectivity index of 5.44 compared to HPBMC cells. For all other target compounds against the other cell lines, $\mathrm{IC}_{50}$ values were $>100 \mu \mathrm{M}$. In general, $\mathrm{IC}_{50}$ concentrations of compounds $\mathbf{2 7 5}$ and $\mathbf{2 7 6}$ increased the percentage of caspase 3/7 activation in the cancer cell lines to a greater degree than 5-FU.

Salas et al. synthesized a series of 31 purine derivatives as potential cytotoxic agents against CFPAC-1, NCI-H460, HL-60, Caco-2, HCT116, K562, MCF-7, MRC-5 cancer cell lines and normal MRC-5 cells [210]. The compounds showed little activity against CFPAC1, Caco-2, and HCT116 cells. For the other four cell lines, the presence of a piperazine containing substituent at $\mathrm{C} 6$ was crucial for maintaining high activity, while a bulky substituent at $\mathrm{C} 2$ was detrimental. Compounds $\mathbf{2 7 7}$ and $\mathbf{2 7 8}$ displayed $\mathrm{IC}_{50}$ values $\leq 2.21$ and $\leq 1.55 \mu \mathrm{M}$, respectively, against the NCI-H460, HL-60, K562, and MCF-7 cell lines, with 278 displaying a selectivity index of $>250$ for HL-60 cells compared to MRC- 5 cells. Compound 279 displayed the greatest potency $\left(\mathrm{IC}_{50}=0.39 \mu \mathrm{M}\right)$ against the $\mathrm{K} 562$ cell line. Compound 278 also induced apoptosis in HL-60 cells at concentrations of $5 \mu \mathrm{M}$ and $50 \mu \mathrm{M}$.

Liu et al. synthesized purinone and imidazotriazinone derivatives as potential antitumor agents and tested these compounds against HepG2 and U-118 MG cancer cell lines [211]. Compound 280 displayed $\mathrm{IC}_{50}$ values of 2.0 and $3.8 \mu \mathrm{M}$, respectively, against these cancer cell lines. Compounds 281 and 282 exhibited $\mathrm{IC}_{50}$ values of 0.5 and $0.4 \mu \mathrm{M}$, respectively, against HepG2 cells. In terms of the general SAR trends, compounds possess- 
ing a purinone core were typically more active against the HepG2 cells compared to target compounds containing an imidazotriazinone core, and introduction of fluorine atoms on the benzyl substituent at N9 and the presence of a longer alkyl group at the C2 position of the purinone core conveyed increased anticancer activity.

Fernández-Sáez et al. synthesized purine derivatives substituted with various heterocyclic rings and evaluated their activity against MCF-7, A375, and HCT116 cancer cell lines [212]. Among these, 3-((2,6-dichloro-9H-purin-9-yl)methyl)-1-tosyl-1,2,3,4-tetrahydroquinoline (compound 283) displayed the greatest potency. Compound 283 displayed $\mathrm{EC}_{50}$ values of 4.26 , 5.54 , and $2.80 \mu \mathrm{M}$ against these cell lines, respectively, while the standard drug 5-FU exhibited $\mathrm{EC}_{50}$ values of 1.50 and $2.40 \mu \mathrm{M}$ against MCF-7 and HCT116 cells. Compound 283 also displayed low cytotoxicity against RFP TERT normal fibroblasts $\left(E_{50}=54.0 \mu \mathrm{M}\right)$ and induced apoptosis in 58\% of MCF-7 cancer cells when incubated with these cells at a concentration of $30 \mu \mathrm{M}$ for $24 \mathrm{~h}$, while apoptosis was observed in less than $10 \%$ of the vehicle control cells.

\section{Conclusions}

Cancer is one of the leading causes of mortality worldwide, placing a huge burden on the healthcare system and exacting a staggering human toll. Despite the many drugs available for treatment of various types of cancer, the side effects, resistance profiles, and variable efficacy of these drugs provides the motivation to discover new anticancer compounds. As illustrated in this review article, considerable attention has been devoted to the synthesis and anticancer evaluation of imidazole and fused imidazole derivatives in recent years. This review summarizes the in vitro and in vivo efficacy studies performed with these derivatives, mechanistic studies conducted on these candidates, and the SAR of the series presented. The work recapped here demonstrates that these imidazole-containing derivatives display anticancer activity through a wide range of mechanisms. While it is impossible to predict with certainty the candidates and approaches described in this review that will have the greatest impact on the treatment of cancer, the following future outlook identifies molecules and strategies that appear to be particularly promising to the authors. Although extensive work on antimicrotubule agents as anticancer compounds has been performed in the past, antitubulin candidates related to compound 8 show outstanding efficacy in murine cancer models $[35,36]$, suggesting that compounds with this scaffold may have a future in cancer therapy. At the time of the writing of this review, a phase 3 trial is being planned to evaluate compound $\mathbf{8}$ for treating metastatic, castration-resistant prostate cancer (ClinicalTrials.gov Identifier: NCT04844749). Kinases are popular drug targets, but there have been selectivity issues due to their structural and sequence similarity. Considering the covalent binding of Nek2 inhibitors 85 and 87 to their putative target [89], such compounds may have enhanced duration of activity, may be effective at a lower dose, and could be less likely to engender drug resistance [213]. Given the effects of lead compound 125 on MCM2, a promising new target, 127 is considered an exciting, potent anticancer candidate considering its efficacy in vivo at doses of just $1 \mathrm{mg} / \mathrm{kg}$ [120] if off-target effects (including CYP450 inhibition and generation of ROS) can be minimized. Despite its challenges, polypharmacology is recognized as a promising strategy for cancer treatment due to the potential of multi-target agents to address the problem of drug resistance [214]. The dual HDAC1/2 and CDK2 inhibitor 141 displays in vivo anticancer efficacy [133], while the pharmacophore fusion strategy reported by He et al. indicated that compound $\mathbf{1 4 4}$ displays potent p53-MDM2/HDAC inhibitory activity and good activity in a murine xenograft model [138], making these molecules intriguing multi-target lead compounds. Compound 150 shows exceptionally tight binding to WDR5, strong inhibition of MLL1 histone methyltransferase activity, and excellent activity against MYC-driven cancer cell lines [144]. Targeting WDR5 may, thus, provide a strategy to exploit MYC, a critical driver of many cancers that has remained difficult to target directly due to its lack of defined small molecule binding sites [215]. Further investigation of the pharmacokinetic properties of compound $\mathbf{1 5 0}$ and its derivatives is, therefore, needed. 
Cutting edge drug discovery approaches, such as NMR-based fragment screening, also represent attractive strategies for the exploitation of WDR5, and, by extension, MYC, for cancer therapy [145]. While no HSP inhibitors have been approved to date, compound 191 is undergoing phase II clinical trials for the treatment of gastrointestinal cancer refractory to current treatments [216], indicating the promise of this agent for cancer treatment.

Our understanding of cancer biology continues to increase, but the development of effective, less toxic therapeutics remains a significant challenge, with drug resistance continuing to represent a major obstacle. Selective attack of key processes/enzymes of vital importance to specific cancers (targeted therapy) has already improved clinical outcomes in cancer [3]; the work summarized in this review shows that the highlighted compounds possessing imidazole/fused imidazole exhibit selectivity towards various targets and display potent activity cancer cell lines compared to normal cell lines. In some cases, minor modifications in a particular scaffold or the inclusion of imidazole via scaffold hopping can result in promising new anticancer activities. Many of the synthesized derivatives reported here display similar or greater potency compared to the reference drugs and promising activity in animal models of cancer, reinforcing both the versatility and utility of the imidazole moiety in modern medicinal chemistry. We hope that this review aids medicinal chemists and other pharmaceutical scientists in the discovery and development of new anticancer compounds with improved efficacy and safety.

Funding: We would like to acknowledge The Ohio State University Comprehensive Cancer Center grant GR112972 for support of PS.

Institutional Review Board Statement: Not applicable.

Informed Consent Statement: Not applicable.

Data Availability Statement: Not applicable.

Conflicts of Interest: The authors declare no conflict of interest.

\section{List of Abbreviations and Cell Lines}

4T1: mouse mammary carcinoma cell line; 5-FU: 5-fluorouracil; 786-0: human renal cancer cell line; A2780: human ovarian cancer cell line; A375: human malignant melanoma cell line; A431: human epidermoid carcinoma cell line; A498: human renal cancer cell line; A549: human lung carcinoma cell line; ACHN: human renal cancer cell line; ACTH: adrenocorticotropic hormone; ADR: adriamycin; AGS: human stomach cancer cell line; ALK5: activin receptor-like kinase 5; ALP: alkaline phosphatase; ALT: alanine aminotransferase; APC/C: anaphase-promoting complex; AST: aspartate aminotransferase; ATM: ataxia telangiectasia mutated serine/threonine kinase; ATR: ataxia telangiectasia mutated and Rad3-related serine/threonine kinase; AUC: area under the curve; AURK: Aurora kinase; B16F10: murine melanoma cell line; BD: bromodomain; Beas-2B: human bronchial epithelial cell line; BEL-7402: human hepatocellular carcinoma cell line; BER: base excision repair; BET: bromodomain and extraterminal; BGC-823: human endocervical adenocarcinoma cell line; BHK: baby hamster kidney cell line; BJ: human normal lung fibroblast; BRCA: breast cancer gene; BSA: bovine serum albumin; BT474: human breast cancer cell line; BT-549: human breast cancer cell line; BTK: Bruton's tyrosine kinase; BxPC-3: human pancreatic cancer cell line; C32: human melanoma cell line; C6: rat glioma cell line; CA 15-3: cancer antigen 15-3; Caco-2: human epithelial colorectal adenocarcinoma cell line; CAL27: human tongue squamous cell carcinoma cell line; Caov-3: human ovarian cancer cell line; Capan-1: human pancreatic adenocarcinoma cell line; CCRF-CEM/VBL: vinblastine-resistant leukemia cell line; CCRF-CEM: human acute T-lymphoblastic leukemia; CDK: cyclin-dependent kinase; CEA: carcinoembryonic antigen; CFPAC-1: human pancreatic adenocarcinoma cell line; Chk: checkpoint kinase; CHP-134: human neuroblastoma cell line; CML: chronic myelogenous leukemia; CNE-1: human nasopharyngeal carcinoma cell line; CT26: colorectal cancer cell line; ct-DNA: calf thymus deoxyribonucleic acid; CYP450: cytochrome P450; Daudi: p53 mutant Burkitt's lymphoma cell line; DLD-1: human colorectal adenocarcinoma cell line; DMF: N, N-dimethyl formamide; DMSO: dimethyl sulfoxide; DSBs: double strand breaks; DU-145: human prostate cancer cell line; $\mathrm{EC}_{50}$ : half maximal effective concentration; EGFR: epidermal growth factor 
receptor; ELISA: enzyme-linked immunoassay; ER: estrogen receptor; EtBr: ethidium bromide; FAK: focal adhesion kinase; FGFR: fibroblast growth factor receptor; FOCUS: human hepatocellular carcinoma cell line; G4s: G-quadruplexes; GES-1: normal human gastric epithelial cell line; GI $_{50}$ : growth inhibitory 50\%; GPCR: G-protein coupled receptor; GST: glutathione S-transferase; H1975: human non-small cell lung cancer cell line; H3255: human lung cancer cell line; H460: human lung cancer cell line; HaCaT: immortalized human keratinocyte cell line; HBL-100: human normal breast cell line; HCC: hepatocellular carcinoma; HCC827: human lung adenocarcinoma cell line; HCT: human colon carcinoma cell line; HCT116: human colorectal carcinoma cell line; HCT-15: human colorectal adenocarcinoma cell line; HDACs: histone deacetylases; HDF: primary human dermal fibroblast; HEK-293: human embryonic kidney cell line; HEK-293T: human embryonic kidney cell line containing the SV40 T-antigen; HeLa: human cervical cancer cell line; Hep3B: human hepatoma cell line; Hep3B-SR: sorafenib resistant hepatocellular carcinoma cancer cell line; HepG2: human liver carcinoma cell line; HFF-1: normal human foreskin fibroblast cell line; HL-60: human promyelocytic leukemia cell line; HL-7702: human normal hepatic cell line; HO-1: heme oxygenase-1; HPBMC: human peripheral blood mononuclear cell line; HR: homologous recombination; HSP: heat shock protein; HT29: human colorectal adenocarcinoma cell line; Huh-7: human hepatoma cell line; Huh7-SR: sorafenib resistant hepatocellular carcinoma cancer cell line; HUVEC: human

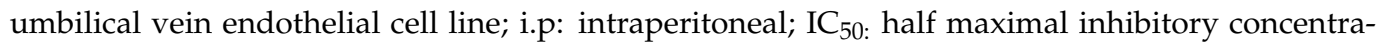
tion; IDO: indoleamine-2,3-dioxygenase; IMR-32: human neuroblastoma cell line; JEKO-1: human mantle cell lymphoma line; Jurkat: human acute T-lymphoblastic leukemia cell line; K562: human chronic myeloid leukemia cell line; $\mathrm{K}_{\mathrm{b}}$ : binding constant; KB: human carcinoma; KB-3-1: human epidermoid carcinoma cell line; KB-C2: multidrug resistant human carcinoma cell line; $\mathrm{K}_{\mathrm{d}}$ : dissociation constant; KDM1A or LSD1: lysine-specific demethylase 1; L929: normal mouse fibroblast cell line; LCK: lymphocyte-specific protein tyrosine kinase; LN-405: human glioblastoma cell line; LO2: human normal liver cell line; LOX: lipoxygenase; M14: human melanoma cell line; Mahlavu: human hepatocellular carcinoma cell line; MAPK: mitogen-activated protein kinase; MCF-10A: human mammary gland epithelial cell line; MCF-10F: human normal breast epithelial cell line; MCF-7: breast cancer cell line; MCM: minichromosomal maintenance protein; MDA-MB-231: human breast adenocarcinoma cancer cell line; MDA-MB-468: human breast adenocarcinoma cancer cell line; MDM2: murine double minute 2; MDR: multidrug resistance; MEK: mitogen-activated protein kinase/ERK kinase (MEK)/extracellular-signal-regulated kinase; MGC-803: gastric cancer cell line; MGM: mean-graph midpoint; MIAPaCa-2: human pancreatic cancer cell line; MKN-45: human gastric adenocarcinoma cell line; MNU: N-methyl-N-nitrosourea; MOLM-13: human acute myeloid leukemia cell line; MRC-5: human normal skin fibroblast; mTOR: mammalian target of rapamycin; MTT: 3-(4,5-dimethylthiazol-2-yl)-2,5-diphenyl tetrazolium bromide; MV4-11: acute myelogenous leukemia cell line; NCI: National Cancer Institute; NCI-H1299: human non-small cell lung carcinoma cell line; NCI-H1975: non-small cell lung carcinoma cell line; NCI-H446: human prostate cancer cell line; NCI-H522: human non-small cell lung cancer cell line; NRK-52E: normal rat kidney epithelial cell line; OVCAR-3: human ovarian cancer cell line; PANC-1: pancreatic cancer cell line; PARP: poly(ADP-ribose)polymerase; PC-3: human prostate cancer cell line; PC-3/TxR: taxane-resistant human PC-3 cell line; PC9: human lung cancer cell line; PCNA: proliferating cell nuclear antigen; P-gp: P-glycoprotein; PI3K: phosphatidylinositol-3-kinase; PLC5: human hepatoma cell line; PLK: Polo like kinase; qPCR: quantitative polymerase chain reaction; RAF: rapidly accelerated fibrosarcoma; Raji: p53 mutant Burkitt's lymphoma cell line; Ramos: non-Hodgkin lymphoma cell line; RFP TERT: immortalized fibroblast cell line; rhIDO1: Recombinant human IDO1; ROS: Reactive oxygen species; RPMI7951: Human skin malignant melanoma cell line; RPMI8226: Human myeloma cell line; RTK: receptor tyrosine kinase; RT-PCR: reverse transcription polymerase chain reaction; SAR: structure-activity relationship; SF-295: human glioblastoma cell line; SFK: Src family kinase; SH-SY5Y: human neuroblastoma cell line; SK-BR-3: HER overexpressing human breast cancer cell line; SK-Mel-2: human malignant melanoma cell line; SKOV3: human ovarian cancer cell line; SMMC-7721: human hepatocarcinoma cell line; SNB-19: human glioblastoma cell line; SPC-A1: human lung adenocarcinoma cell line; SPR: surface plasmon resonance; SR: human leukemia cell line; STAT3: signal transducer and activator of transcription 3; SU-DHL-4: human follicular B-cell lymphoma cell line; SU-DHL-6: human follicular B-cell lymphoma cell line; SW48: human colorectal 
carcinoma cell line; SW480: Human colorectal adenocarcinoma cell line; SW620: metastatic colorectal adenocarcinoma cell line; T47D: human ductal breast epithelial tumor cell line; TDO: tryptophan 2,3-dioxygenase; TE-1: human squamous cell carcinoma line; TGF- $\beta$ : transforming growth factor- $\beta$; TGI: tumor growth inhibition; hERG: human ether-a-go-go-related gene; THP-1: human leukemia cell line; TKI: tyrosine kinase inhibitor; TPSA; Total polar surface area; TopI: type 1 topoisomerases; TopII: type 2 topoisomerases; U.S. FDA: United States Food and Drug Administration; U-118 MG: human glioblastoma cell line; U2OS: human osteosarcoma cell line; U87: human glioblastoma cell line; U87MG: human glioblastoma cell line; VEGFR-2: vascular endothelial growth factor receptor 2; Vero: Normal African green monkey kidney cell line; W138: Human normal embryonic lung cell line; WDR5: WD repeat domain 5; WM164: human melanoma cell line; WS-1: human normal skin fibroblast cell line; YCC11: HDAC inhibitor sensitive gastric cancer cell line; YCC3/7: HDAC inhibitor resistant gastric cancer cell line; $\Delta T m$ : melting temperature.

\section{References}

1. Wild, C.P.; Weiderpass, E.; Stewart, B.W. World Cancer Report: Cancer Research for Cancer Prevention; International Agency for Research on Cancer: Lyon, France, 2021; Available online: http:/ / publications.iarc.fr/586 (accessed on 8 February 2021).

2. Tsimberidou, A.M. Targeted therapy in cancer. Cancer Chemother. Pharmacol. 2015, 76, 1113-1132. [CrossRef]

3. Seebacher, N.A.; Stacy, A.E.; Porter, G.M.; Merlot, A.M. Clinical development of targeted and immune based anti-cancer therapies. J. Exp. Clin. Cancer Res. 2019, 38, 156. [CrossRef] [PubMed]

4. Rana, A.; Alex, J.; Chauhan, M.; Joshi, G.; Kumar, R. A review on pharmacophoric designs of antiproliferative agents. Med. Chem. Res. 2015, 24, 903-920. [CrossRef]

5. Vitaku, E.; Smith, D.T.; Njardarson, J.T. Analysis of the structural diversity, substitution patterns, and frequency of nitrogen heterocycles among U.S. FDA approved pharmaceuticals. J. Med. Chem. 2014, 57, 10257-10274. [CrossRef]

6. Ali, I.; Lone, M.N.; Aboul-Enein, H.Y. Imidazoles as potential anticancer agents. Med. Chem. Commun. 2017, 8, 1742-1773. [CrossRef] [PubMed]

7. Rani, N.; Sharma, A.; Singh, R. Imidazoles as promising scaffolds for antibacterial activity: A review. Mini Rev. Med. Chem. 2013, 13, 1812-1835. [CrossRef] [PubMed]

8. Zhan, P.; Liu, X.; Zhu, J.; Fang, Z.; Li, Z.; Pannecouque, C.; de Clercq, E. Synthesis and biological evaluation of imidazole thioacetanilides as novel non-nucleoside HIV-1 reverse transcriptase inhibitors. Bioorg. Med. Chem. 2009, 17, 5775-5781. [CrossRef]

9. Mishra, R.; Ganguly, S. Imidazole as an anti-epileptic: An overview. Med. Chem. Res. 2012, 21, 3929-3939. [CrossRef]

10. Fan, Y.L.; Jin, X.H.; Huang, Z.P.; Yu, H.F.; Zeng, Z.G.; Gao, T.; Feng, L.S. Recent advances of imidazole-containing derivatives as anti-tubercular agents. Eur. J. Med. Chem. 2018, 150, 347-365. [CrossRef]

11. Rani, N.; Sharma, A.; Gupta, G.K.; Singh, R. Imidazoles as potential antifungal agents: A review. Mini Rev. Med. Chem. 2013, 13, 1626-1655. [CrossRef] [PubMed]

12. Wattanasin, P.; Saetear, P.; Wilairat, P.; Nacapricha, D.; Teerasong, S. Zone fluidics for measurement of octanol-water partition coefficient of drugs. Anal. Chim. Acta 2015, 860, 1-7. [CrossRef]

13. Molina, P.; Tárraga, A.; Otón, F. Imidazole derivatives: A comprehensive survey of their recognition properties. Org. Biomol. Chem. 2012, 10, 1711-1724. [CrossRef] [PubMed]

14. Chen, S.-S. The roles of imidazole ligands in coordination supramolecular systems. Cryst. Eng. Comm 2016, 18, 6543-6565. [CrossRef]

15. Zhang, L.; Peng, X.-M.; Damu, G.L.V.; Geng, R.-X.; Zhou, C.-H. Comprehensive review in current developments of imidazolebased medicinal chemistry. Med. Res. Rev. 2014, 34, 340-437. [CrossRef] [PubMed]

16. Debus, H. Ueber die einwirkung des ammoniaks auf glyoxal. Justus Liebigs Ann. Chem. 1858, 107, 199-208. [CrossRef]

17. Radziszewski, B. Ueber die constitution des lophins und verwandter verbindungen. Chem. Ber. 1882, 15, 1493-1496. [CrossRef]

18. Benincori, T.; Brenna, E.; Sannicolo, F. Studies on Wallach's imidazole synthesis. J. Chem. Soc. Perkin Trans. 1993, 1, 675-679. [CrossRef]

19. Marckwald, W. Ein beitrag zur kenntniss der imidazole und der constitution des glyoxalins. Chem. Ber. 1892, $25,2354-2362$. [CrossRef]

20. Sharma, A.; Kumar, V.; Kharb, R.; Kumar, S.; Sharma, P.C.; Pathak, D.P. Imidazole derivatives as potential therapeutic agents. Curr. Pharm. Des. 2016, 22, 3265-3301. [CrossRef]

21. Vessaly, E.; Soleimani-Amiri, S.; Hosseinian, A.; Edjlali, L.; Bekhradnia, A. New protocols to access imidazoles and their ring fused analogues: Synthesis from N-propargylamines. RSC Adv. 2017, 7, 7079-7091. [CrossRef]

22. Hossain, M.; Nanda, A.K. A review on heterocyclic: Synthesis and their application in medicinal chemistry of imidazole moiety. Sci. J. Chem. 2018, 6, 83-94. [CrossRef]

23. Soni, J.; Sethiya, A.; Sahiba, N.; Agarwal, D.K.; Agarwal, S. Contemporary progress in the synthetic strategies of imidazole and its biological activities. Curr. Org. Synth. 2019, 16, 1078-1104. [CrossRef] [PubMed] 
24. Shabalin, D.A.; Camp, J.E. Recent advances in the synthesis of imidazoles. Org. Biomol. Chem. 2020, 18, 3950-3964. [CrossRef]

25. Alaqeel, S.I. Synthetic approaches to benzimidazoles from o-phenylenediamine: A literature review. J. Saudi Chem. Soc. 2017, 21, 229-237. [CrossRef]

26. Traube, W. Ueber eine neue synthese des guanins und xanthins. Chem. Ber. 1900, 33, 1371-1383. [CrossRef]

27. Zelli, R.; Zeinyeh, W.; Haudecoeur, R.; Alliot, J.; Boucherle, B.; Callebaut, I.; Décout, J.L. A one-pot synthesis of highly functionalized purines. Org. Lett. 2017, 19, 6360-6363. [CrossRef] [PubMed]

28. Akhtar, W.; Khan, M.F.; Verma, G.; Shaquiquzzaman, M.; Rizvi, M.A.; Mehdi, S.H.; Akhter, M.; Alam, M.M. Therapeutic evolution of benzimidazole derivatives in the last quinquennial period. Eur. J. Med. Chem. 2017, 126, 705-753. [CrossRef] [PubMed]

29. Siwach, A.; Verma, P.K. Synthesis and therapeutic potential of imidazole containing compounds. BMC Chem. 2021, 15, 12. [CrossRef]

30. Florian, S.; Mitchison, T.J. Anti-microtubule drugs. Methods Mol. Biol. 2016, 1413, 403-421. [PubMed]

31. de Weger, V.A.; Beijnen, J.H.; Schellens, J.H. Cellular and clinical pharmacology of the taxanes docetaxel and paclitaxel-A review. Anticancer Drugs 2014, 25, 488-494. [CrossRef]

32. Martino, E.; Casamassima, G.; Castiglione, S.; Cellupica, E.; Pantalone, S.; Papagni, F.; Rui, M.; Siciliano, A.M.; Collina, S. Vinca alkaloids and analogues as anti-cancer agents: Looking back, peering ahead. Bioorg. Med. Chem. Lett. 2018, 28, 2816-2826. [CrossRef]

33. Li, J.; Ren, J.; Sun, W. Systematic review of ixabepilone for treating metastatic breast cancer. Breast Cancer 2017, 24, 171-179. [CrossRef] [PubMed]

34. Li, L.; Quan, D.; Chen, J.; Ding, J.; Zhao, J.; Lv, L.; Chen, J. Design, synthesis, and biological evaluation of 1-substituted -2-aryl imidazoles targeting tubulin polymerization as potential anticancer agents. Eur. J. Med. Chem. 2019, 184, 111732. [CrossRef] [PubMed]

35. Wang, Q.; Arnst, K.E.; Wang, Y.; Kumar, G.; Ma, D.; Chen, H.; Wu, Z.; Yang, J.; White, S.W.; Miller, D.D.; et al. Structural modification of the 3,4,5-trimethoxyphenyl moiety in the tubulin inhibitor VERU-111 leads to improved antiproliferative activities. J. Med. Chem. 2018, 61, 7877-7891. [CrossRef]

36. Wang, Q.; Arnst, K.E.; Wang, Y.; Kumar, G.; Ma, D.; White, S.W.; Miller, D.D.; Li, W.; Li, W. Structure-guided design, synthesis, and biological evaluation of (2-(1H-indol-3-yl)-1H-imidazol-4-yl)(3,4,5-trimethoxyphenyl) methanone (ABI-231) analogues targeting the colchicine binding site in tubulin. J. Med. Chem. 2019, 62, 6734-6750. [CrossRef] [PubMed]

37. Bai, Z.; Liu, X.; Guan, Q.; Ding, N.; Wei, Q.; Tong, B.; Zhao, M.; Zhang, W.; Ma, L. 5-(3,4,5-trimethoxybenzoyl)-4-methyl-2-(p-tolyl) imidazol (BZML) targets tubulin and DNA to induce anticancer activity and overcome multidrug resistance in colorectal cancer cells. Chem. Biol. Interact. 2020, 315, 108886. [CrossRef]

38. Sayeed, I.B.; Vishnuvardhan, M.V.P.S.; Nagarajan, A.; Kantevari, S.; Kamal, A. Imidazopyridine linked triazoles as tubulin inhibitors, effectively triggering apoptosis in lung cancer cell line. Bioorg. Chem. 2018, 80, 714-720. [CrossRef] [PubMed]

39. Narasimha Rao, M.P.; Nagaraju, B.; Kovvuri, J.; Polepalli, S.; Alavala, S.; Vishnuvardhan, M.V.P.S.; Swapna, P.; Nimbarte, V.D.; Lakshmi, J.K.; Jain, N.; et al. Synthesis of imidazo-thiadiazole linked indolinone conjugates and evaluated their microtubule network disrupting and apoptosis inducing ability. Bioorg. Chem. 2018, 76, 420-436. [CrossRef] [PubMed]

40. Baig, M.F.; Nayak, V.L.; Budaganaboyina, P.; Mullagiri, K.; Sunkari, S.; Gour, J.; Kamal, A. Synthesis and biological evaluation of imidazo[2,1-b]thiazole-benzimidazole conjugates as microtubule-targeting agents. Bioorg. Chem. 2018, 77, 515-526. [CrossRef] [PubMed]

41. Donthiboina, K.; Anchi, P.; Gurram, S.; Sai Mani, G.; Lakshmi Uppu, J.; Godugu, C.; Shankaraiah, N.; Kamal, A. Synthesis and biological evaluation of substituted $\mathrm{N}-(2-(1 H$-benzo[d]imidazol-2-yl)phenyl)cinnamides as tubulin polymerization inhibitors. Bioorg. Chem. 2020, 103, 104191. [CrossRef]

42. Wang, Y.T.; Shi, T.Q.; Zhu, H.L.; Liu, C.H. Synthesis, biological evaluation and molecular docking of benzimidazole grafted benzsulfamide-containing pyrazole ring derivatives as novel tubulin polymerization inhibitors. Bioorg. Med. Chem. 2019, 27, 502-515. [CrossRef] [PubMed]

43. Zhang, Q.; Hu, X.; Wan, G.; Wang, J.; Li, L.; Wu, X.; Liu, Z.; Yu, L. Discovery of 3-(((9H-purin-6-yl)amino)methyl)-4,6dimethylpyridin-2 $(1 H)$-one derivatives as novel tubulin polymerization inhibitors for treatment of cancer. Eur. J. Med. Chem. 2019, 184, 111728. [CrossRef] [PubMed]

44. Hu, X.; Li, L.; Zhang, Q.; Wang, Q.; Feng, Z.; Xu, Y.; Xia, Y.; Yu, L. Design, synthesis and biological evaluation of a novel tubulin inhibitor SKLB0565 targeting the colchicine binding site. Bioorg. Chem. 2020, 97, 103695. [CrossRef] [PubMed]

45. Huang, P.; Le, X.; Huang, F.; Yang, J.; Yang, H.; Ma, J.; Hu, G.; Li, Q.; Chen, Z. Discovery of a dual tubulin polymerization and cell division cycle 20 homologue inhibitor via structural modification on apcin. J. Med. Chem. 2020, 63, 4685-4700. [CrossRef] [PubMed]

46. Wang, L.; Zhang, J.; Wan, L.; Zhou, X.; Wang, Z.; Wei, W. Targeting Cdc20 as a novel cancer therapeutic strategy. Pharmacol. Ther. 2015, 151, 141-151. [CrossRef] [PubMed]

47. Jimenez, P.C.; Wilke, D.V.; Branco, P.C.; Bauermeister, A.; Rezende-Teixeira, P.; Gaudêncio, S.P.; Costa-Lotufo, L.V. Enriching cancer pharmacology with drugs of marine origin. Br. J. Pharmacol. 2020, 177, 3-27. [CrossRef] [PubMed]

48. Ding, Z.; Ma, M.; Zhong, C.; Wang, S.; Fu, Z.; Hou, Y.; Liu, Y.; Zhong, L.; Chu, Y.; Li, F.; et al. Development of novel phenoxydiketopiperazine-type plinabulin derivatives as potent antimicrotubule agents based on the co-crystal structure. Bioorg. Med. Chem. 2020, 28, 115186. [CrossRef] [PubMed] 
49. Roskoski, R., Jr. Properties of FDA-approved small molecule protein kinase inhibitors: A 2020 update. Pharmacol. Res. 2020, 152, 104609. [CrossRef]

50. Karaman, S.; Leppänen, V.M.; Alitalo, K. Vascular endothelial growth factor signaling in development and disease. Development 2018, 145, dev151019. [CrossRef]

51. Apte, R.S.; Chen, D.S.; Ferrara, N. VEGF in signaling and disease: Beyond discovery and development. Cell 2019, 176, 1248-1264. [CrossRef]

52. Randrup Hansen, C.; Grimm, D.; Bauer, J.; Wehland, M.; Magnusson, N.E. Effects and side effects of using sorafenib and sunitinib in the treatment of metastatic renal cell carcinoma. Int. J. Mol. Sci. 2017, 18, 461. [CrossRef] [PubMed]

53. Yuan, X.; Yang, Q.; Liu, T.; Li, K.; Liu, Y.; Zhu, C.; Zhang, Z.; Li, L.; Zhang, C.; Xie, M.; et al. Design, synthesis and in vitro evaluation of 6-amide-2-aryl benzoxazole/benzimidazole derivatives against tumor cells by inhibiting VEGFR-2 kinase. Eur. J. Med. Chem. 2019, 179, 147-165. [CrossRef]

54. Mostafa, A.S.; Gomaa, R.M.; Elmorsy, M.A. Design and synthesis of 2-phenyl benzimidazole derivatives as VEGFR-2 inhibitors with anti-breast cancer activity. Chem. Biol. Drug Des. 2019, 93, 454-463. [CrossRef]

55. Sigismund, S.; Avanzato, D.; Lanzetti, L. Emerging functions of the EGFR in cancer. Mol. Oncol. 2018, 12, 3-20. [CrossRef]

56. Akhtar, M.J.; Khan, A.A.; Ali, Z.; Dewangan, R.P.; Rafi, M.; Hassan, M.Q.; Akhtar, M.S.; Siddiqui, A.A.; Partap, S.; Pasha, S.; et al. Synthesis of stable benzimidazole derivatives bearing pyrazole as anticancer and EGFR receptor inhibitors. Bioorg. Chem. 2018, 78, 158-169. [CrossRef] [PubMed]

57. Hei, Y.Y.; Shen, Y.; Wang, J.; Zhang, H.; Zhao, H.Y.; Xin, M.; Cao, Y.X.; Li, Y.; Zhang, S.Q. Synthesis and evaluation of 2,9disubstituted 8-phenylthio/phenylsulfinyl-9H-purine as new EGFR inhibitors. Bioorg. Med. Chem. 2018, 26, 2173-2185. [CrossRef]

58. Lei, H.; Fan, S.; Zhang, H.; Liu, Y.J.; Hei, Y.Y.; Zhang, J.J.; Zheng, A.Q.; Xin, M.; Zhang, S.Q. Discovery of novel 9-heterocyclyl substituted 9H-purines as L858R/T790M/C797S mutant EGFR tyrosine kinase inhibitors. Eur. J. Med. Chem. 2020, 186, 111888. [CrossRef] [PubMed]

59. Abou-Zied, H.A.; Youssif, B.G.M.; Mohamed, M.F.A.; Hayallah, A.M.; Abdel-Aziz, M. EGFR inhibitors and apoptotic inducers: Design, synthesis, anticancer activity and docking studies of novel xanthine derivatives carrying chalcone moiety as hybrid molecules. Bioorg. Chem. 2019, 89, 102997. [CrossRef] [PubMed]

60. Hisham, M.; Youssif, B.G.M.; Osman, E.E.A.; Hayallah, A.M.; Abdel-Aziz, M. Synthesis and biological evaluation of novel xanthine derivatives as potential apoptotic antitumor agents. Eur. J. Med. Chem. 2019, 176, 117-128. [CrossRef] [PubMed]

61. Srour, A.M.; Ahmed, N.S.; Abd El-Karim, S.S.; Anwar, M.M.; El-Hallouty, S.M. Design, synthesis, biological evaluation, QSAR analysis and molecular modelling of new thiazol-benzimidazoles as EGFR inhibitors. Bioorg. Med. Chem. 2020, $28,115657$. [CrossRef] [PubMed]

62. Kalra, S.; Joshi, G.; Kumar, M.; Arora, S.; Kaur, H.; Singh, S.; Munshi, A.; Kumar, R. Anticancer potential of some imidazole and fused imidazole derivatives: Exploring the mechanism via epidermal growth factor receptor (EGFR) inhibition. RSC Med. Chem. 2020, 11, 923-939. [CrossRef]

63. Roskoski, R., Jr. Src protein-tyrosine kinase structure, mechanism, and small molecule inhibitors. Pharmacol. Res. 2015, 94, 9-25. [CrossRef] [PubMed]

64. Francini, C.M.; Musumeci, F.; Fallacara, A.L.; Botta, L.; Molinari, A.; Artusi, R.; Mennuni, L.; Angelucci, A.; Schenone, S. Optimization of aminoimidazole derivatives as Src family kinase inhibitors. Molecules 2018, 23, 2369. [CrossRef]

65. Rezaei, Z.; Mahdi Didehvar, M.; Mahdavi, M.; Azizian, H.; Hamedifar, H.; Mohammed, E.H.M.; Ostad, S.; Amini, M. Anticancer properties of $\mathrm{N}$-alkyl-2, 4-diphenylimidazo [1, 2-a] quinoxalin-1-amine derivatives; kinase inhibitors. Bioorg. Chem. 2019, 90, 103055. [CrossRef] [PubMed]

66. Rossari, F.; Minutolo, F.; Orciuolo, E. Past, present, and future of Bcr-Abl inhibitors: From chemical development to clinical efficacy. J. Hematol. Oncol. 2018, 11, 84. [CrossRef]

67. Wen, T.; Wang, J.; Shi, Y.; Qian, H.; Liu, P. Inhibitors targeting Bruton's tyrosine kinase in cancers: Drug development advances. Leukemia 2021, 35, 312-332. [CrossRef]

68. Bertrand, J.; Dostálová, H.; Krystof, V.; Jorda, R.; Castro, A.; Mella, J.; Espinosa-Bustos, C.; María Zarate, A.; Salas, C.O. New 2,6,9-trisubstituted purine derivatives as Bcr-Abl and Btk inhibitors and as promising agents against leukemia. Bioorg. Chem. 2020, 94, 103361. [CrossRef] [PubMed]

69. Haque, S.; Morris, J.C. Transforming growth factor- $\beta$ : A therapeutic target for cancer. Hum. Vaccin. Immunother. 2017, 13, 1741-1750. [CrossRef]

70. Guo, Z.; Song, X.; Zhao, L.M.; Piao, M.G.; Quan, J.; Piao, H.R.; Jin, C.H. Synthesis and biological evaluation of novel benzo[c][1,2,5]thiadiazol-5-yl and thieno[3,2-c]-pyridin-2-yl imidazole derivatives as ALK5 inhibitors. Bioorg. Med. Chem. Lett. 2019, 29, 2070-2075. [CrossRef] [PubMed]

71. Manic, G.; Obrist, F.; Sistigu, A.; Vitale, I. Trial watch: Targeting ATM-CHK2 and ATR-CHK1 pathways for anticancer therapy. Mol. Cell Oncol. 2015, 2, e1012976. [CrossRef] [PubMed]

72. Meuth, M. Chk1 suppressed cell death. Cell Div. 2010, 5, 21. [CrossRef]

73. Ronco, C.; Martin, A.R.; Demange, L.; Benhida, R. ATM, ATR, CHK1, CHK2 and WEE1 inhibitors in cancer and cancer stem cells. Med. Chem. Commun. 2017, 8, 295-319. [CrossRef] 
74. Galal, S.A.; Khairat, S.H.M.; Ali, H.I.; Shouman, S.A.; Attia, Y.M.; Ali, M.M.; Mahmoud, A.E.; Abdel-Halim, A.H.; Fyiad, A.A.; Tabll, A.; et al. Part II: New candidates of pyrazole-benzimidazole conjugates as checkpoint kinase 2 (Chk2) inhibitors. Eur. J. Med. Chem. 2018, 144, 859-873. [CrossRef]

75. Galal, S.A.; Khattab, M.; Shouman, S.A.; Ramadan, R.; Kandil, O.M.; Kandil, O.M.; Tabll, A.; El Abd, Y.S.; El-Shenawy, R.; Attia, Y.M.; et al. Part III: Novel checkpoint kinase 2 (Chk2) inhibitors; design, synthesis and biological evaluation of pyrimidinebenzimidazole conjugates. Eur. J. Med. Chem. 2018, 146, 687-708. [CrossRef]

76. Karoulia, Z.; Gavathiotis, E.; Poulikakos, P.I. New perspectives for targeting RAF kinase in human cancer. Nat. Rev. Cancer 2017, 17, 676-691. [CrossRef]

77. Asati, V.; Mahapatra, D.K.; Bharti, S.K. PI3K/Akt/mTOR and Ras/Raf/MEK/ERK signaling pathways inhibitors as anticancer agents: Structural and pharmacological perspectives. Eur. J. Med. Chem. 2016, 109, 314-341. [CrossRef] [PubMed]

78. Abdel-Maksoud, M.S.; Ammar, U.M.; Oh, C.H. Anticancer profile of newly synthesized BRAF inhibitors possess 5-(pyrimidin-4yl)imidazo[2,1-b]thiazole scaffold. Bioorg. Med. Chem. 2019, 27, 2041-2051. [CrossRef]

79. Malumbres, M. Cyclin-dependent kinases. Genome Biol. 2014, 15, 122. [CrossRef] [PubMed]

80. Shapiro, G.I. The evolving role of cyclin-dependent kinase inhibitors in cancer management. Clin. Adv. Hematol. Oncol. 2017, 15, 174-177. [PubMed]

81. Sánchez-Martínez, C.; Lallena, M.J.; Sanfeliciano, S.G.; de Dios, A. Cyclin dependent kinase (CDK) inhibitors as anticancer drugs: Recent advances (2015-2019). Bioorg. Med. Chem. Lett. 2019, 29, 126637. [CrossRef]

82. Al-Warhi, T.; Said, M.A.; El Hassab, M.A.; Aljaeed, N.; Ghabour, H.A.; Almahli, H.; Eldehna, W.M.; Abdel-Aziz, H.A. Unexpected synthesis, single-crystal x-ray structure, anticancer activity, and molecular docking studies of certain 2-((imidazole/benzimidazol2-yl)thio)-1-arylethanones. Crystals 2020, 10, 446. [CrossRef]

83. Wang, Y.; Liu, W.J.; Yin, L.; Li, H.; Chen, Z.H.; Zhu, D.X.; Song, X.Q.; Cheng, Z.Z.; Song, P.; Wang, Z.; et al. Design and synthesis of 4-(2,3-dihydro-1H-benzo[d]pyrrolo[1,2-a]imidazol-7-yl)- $N$-(5-(piperazin-1-ylmethyl)pyridine-2-yl)pyrimidin-2-amine as a highly potent and selective cyclin-dependent kinases 4 and 6 inhibitors and the discovery of structure-activity relationships. Bioorg. Med. Chem. Lett. 2018, 28, 974-978.

84. Ghanem, N.M.; Farouk, F.; George, R.F.; Abbas, S.E.S.; El-Badry, O.M. Design and synthesis of novel imidazo[4,5- $b]$ pyridine based compounds as potent anticancer agents with CDK9 inhibitory activity. Bioorg. Chem. 2018, 80, 565-576. [CrossRef]

85. Bavetsias, V.; Linardopoulos, S. Aurora kinase inhibitors: Current status and outlook. Front. Oncol. 2015, 5, 278. [CrossRef]

86. Fan, C.; Zhong, T.; Yang, H.; Yang, Y.; Wang, D.; Yang, X.; Xu, Y.; Fan, Y. Design, synthesis, biological evaluation of 6-(2-amino-1Hbenzo[d]imidazole-6-yl)quinazolin-4(3H)-one derivatives as novel anticancer agents with Aurora kinase inhibition. Eur. J. Med. Chem. 2020, 190, 112108. [CrossRef]

87. Fang, Y.; Zhang, X. Targeting NEK2 as a promising therapeutic approach for cancer treatment. Cell Cycle 2016, 15, 895-907. [CrossRef]

88. Wang, H.; Chen, Y.; Gu, X.; Xi, J.; Ren, Z.; Wang, S.; Duan, Y.; Li, H.; Zhu, T.; Du, Y.; et al. Design, synthesis, and structure activity relationship (SAR) studies of novel imidazo[1,2-a] pyridine derivatives as Nek2 inhibitors. Bioorg. Med. Chem. 2020, $28,115775$. [CrossRef]

89. Matheson, C.J.; Coxon, C.R.; Bayliss, R.; Boxall, K.; Carbain, B.; Fry, A.M.; Hardcastle, I.R.; Harnor, S.J.; Mas-Droux, C.; Newell, D.R.; et al. 2-Arylamino-6-ethynylpurines are cysteine-targeting irreversible inhibitors of Nek2 kinase. RSC Med. Chem. 2020, 11, 707-731. [CrossRef]

90. Yang, J.; Nie, J.; Ma, X.; Wei, Y.; Peng, Y.; Wei, X. Targeting PI3K in cancer: Mechanisms and advances in clinical trials. Mol. Cancer 2019, 18, 26. [CrossRef] [PubMed]

91. Curigliano, G.; Shah, R. Safety and tolerability of phosphatidylinositol-3-kinase (PI3K) inhibitors in oncology. Drug Saf. 2019, 42, 247-262. [CrossRef]

92. Markham, A. Alpelisib: First global approval. Drugs 2019, 79, 1249-1253. [CrossRef] [PubMed]

93. Ding, H.W.; Yu, L.; Bai, M.X.; Qin, X.C.; Song, M.T.; Zhao, Q.C. Design, synthesis and evaluation of some 1,6-disubstituted-1Hbenzo[ $d$ ] imidazoles derivatives targeted PI3K as anticancer agents. Bioorg. Chem. 2019, 93, 103283. [CrossRef] [PubMed]

94. Xiao, Z.; Lei, F.; Chen, X.; Wang, X.; Cao, L.; Ye, K.; Zhu, W.; Xu, S. Design, synthesis, and antitumor evaluation of quinolineimidazole derivatives. Arch. Pharm. 2018, 351, e1700407. [CrossRef]

95. Wu, T.T.; Guo, Q.Q.; Chen, Z.L.; Wang, L.L.; Du, Y.; Chen, R.; Mao, Y.H.; Yang, S.G.; Huang, J.; Wang, J.T.; et al. Design, synthesis and bioevaluation of novel substituted triazines as potential dual PI3K/mTOR inhibitors. Eur. J. Med. Chem. 2020, $204,112637$. [CrossRef]

96. Yang, Y.; Chen, H.; Liu, Q.; Sun, Y.; Gu, W. Synthesis and anticancer evaluation of novel $1 H$-benzo[d]imidazole derivatives of dehydroabietic acid as PI3K $\alpha$ inhibitors. Bioorg. Chem. 2020, 100, 103845. [CrossRef]

97. Zuo, W.Q.; Hu, R.; Wang, W.L.; Zhu, Y.X.; Xu, Y.; Yu, L.T.; Liu, Z.H.; Wang, N.Y. Identification of a potent and selective phosphatidylinositol 3-kinase $\delta$ inhibitor for the treatment of non-Hodgkin's lymphoma. Bioorg. Chem. 2020, 105, 104344. [CrossRef] [PubMed]

98. Gaonkar, S.; Savanur, M.A.; Sunagar, M.G.; Puthusseri, B.; Deshapande, N.; Nadaf, A.A.; Khazi, I.A.M. Exploring the potential of newly synthesized 4-methyl-6-morpholino-pyrimidine derivatives as antiproliferative agents. New J. Chem. 2018, 42, $2790-2803$. [CrossRef] 
99. Sutherlin, D.P.; Bao, L.; Berry, M.; Castanedo, G.; Chuckowree, I.; Dotson, J.; Folks, A.; Friedman, L.; Goldsmith, R.; Gunzner, J.; et al. Discovery of a potent, selective, and orally available class I phosphatidylinositol 3-kinase (PI3K)/mammalian target of rapamycin (mTOR) kinase inhibitor (GDC-0980) for the treatment of cancer. J. Med. Chem. 2011, 54, 7579-7587. [CrossRef] [PubMed]

100. Rescifina, A.; Zagni, C.; Varrica, M.G.; Pistarà, V.; Corsaro, A. Recent advances in small organic molecules as DNA intercalating agents: Synthesis, activity, and modeling. Eur. J. Med. Chem. 2014, 74, 95-115. [CrossRef] [PubMed]

101. Sharma, V.; Gupta, M.; Kumar, P.; Sharma, A. A comprehensive review on fused heterocyclic as DNA intercalators: Promising anticancer agents. Curr. Pharm. Des. 2021, 27, 15-42. [CrossRef]

102. Zhao, F.; Wang, W.; Lu, W.; Xu, L.; Yang, S.; Cai, X.M.; Zhou, M.; Lei, M.; Ma, M.; Xu, H.J.; et al. High anticancer potency on tumor cells of dehydroabietylamine Schiff-base derivatives and a copper(II) complex. Eur. J. Med. Chem. 2018, 146, 451-459. [CrossRef] [PubMed]

103. Zhao, F.; Lu, W.; Su, F.; Xu, L.; Jiang, D.; Sun, X.; Shi, J.; Zhou, M.; Lin, F.; Cao, F. Synthesis and potential antineoplastic activity of dehydroabietylamine imidazole derivatives. Med. Chem. Commun. 2018, 9, 2091-2099. [CrossRef]

104. Singh, I.; Luxami, V.; Paul, K. Synthesis and in vitro evaluation of naphthalimide-benzimidazole conjugates as potential antitumor agents. Org. Biomol. Chem. 2019, 17, 5349-5366. [CrossRef] [PubMed]

105. Singh, I.; Luxami, V.; Paul, K. Effective synthesis of benzimidazoles-imidazo[1,2-a]pyrazine conjugates: A comparative study of mono-and bis-benzimidazoles for antitumor activity. Eur. J. Med. Chem. 2019, 180, 546-561. [CrossRef]

106. Singh, I.; Luxami, V.; Paul, K. Synthesis, cytotoxicity, pharmacokinetic profile, binding with DNA and BSA of new imidazo[1,2a]pyrazine-benzo[d]imidazol-5-yl hybrids. Sci. Rep. 2020, 10, 6534. [CrossRef] [PubMed]

107. Singh, I.; Rani, R.; Luxami, V.; Paul, K. Synthesis of 5-(4-(1H-phenanthro[9,10- $d]$ imidazol-2-yl)benzylidene)thiazolidine-2,4-dione as promising DNA and serum albumin-binding agents and evaluation of antitumor activity. Eur. J. Med. Chem. 2019, 166, 267-280. [CrossRef] [PubMed]

108. Nakanishi, C.; Seimiya, H. G-quadruplex in cancer biology and drug discovery. Biochem. Biophys. Res. Commun. 2020, 531, 45-50. [CrossRef] [PubMed]

109. Simonsson, T.; Pecinka, P.; Kubista, M. DNA tetraplex formation in the control region of c-myc. Nucleic Acids Res. 1998, 26, 1167-1172. [CrossRef] [PubMed]

110. Liu, H.Y.; Chen, A.C.; Yin, Q.K.; Li, Z.; Huang, S.M.; Du, G.; He, J.H.; Zan, L.P.; Wang, S.K.; Xu, Y.H.; et al. New disubstituted quindoline derivatives inhibiting Burkitt's lymphoma cell proliferation by impeding c-MYC transcription. J. Med. Chem. 2017, 60, 5438-5454. [CrossRef]

111. Wu, Q.; Song, Y.; Liu, R.; Wang, R.; Mei, W.; Chen, W.; Yang, H.; Wang, X. Synthesis, docking studies and antitumor activity of phenanthroimidazole derivatives as promising c-myc G-quadruplex DNA stabilizers. Bioorg. Chem. 2020, 102, 104074. [CrossRef]

112. Pelliccia, S.; Amato, J.; Capasso, D.; Di Gaetano, S.; Massarotti, A.; Piccolo, M.; Irace, C.; Tron, G.C.; Pagano, B.; Randazzo, A.; et al. Bio-inspired dual-selective $B C L-2 / c-M Y C$ G-quadruplex binders: Design, synthesis, and anticancer activity of drug-like imidazo[2,1-i]purine derivatives. J. Med. Chem. 2020, 63, 2035-2050. [CrossRef] [PubMed]

113. Cesare, A.J.; Reddel, R.R. Alternative lengthening of telomeres: Models, mechanisms and implications. Nat. Rev. Genet. 2010, 11, 319-330. [CrossRef]

114. Hu, M.H.; Lin, X.T.; Liu, B.; Tan, J.H. Dimeric aryl-substituted imidazoles may inhibit ALT cancer by targeting the multimeric G-quadruplex in telomere. Eur. J. Med. Chem. 2020, 186, 111891. [CrossRef] [PubMed]

115. Delgado, J.L.; Hsieh, C.M.; Chan, N.L.; Hiasa, H. Topoisomerases as anticancer targets. Biochem. J. 2018, 475, 373-398. [CrossRef]

116. Liang, X.; Wu, Q.; Luan, S.; Yin, Z.; He, C.; Yin, L.; Zou, Y.; Yuan, Z.; Li, L.; Song, X.; et al. A comprehensive review of topoisomerase inhibitors as anticancer agents in the past decade. Eur. J. Med. Chem. 2019, 171, 129-168. [CrossRef] [PubMed]

117. Kundu, B.; Das, S.K.; Paul Chowdhuri, S.; Pal, S.; Sarkar, D.; Ghosh, A.; Mukherjee, A.; Bhattacharya, D.; Das, B.B.; Talukdar, A. Discovery and mechanistic study of tailor-made quinoline derivatives as topoisomerase 1 poison with potent anticancer activity. J. Med. Chem. 2019, 62, 3428-3446. [CrossRef]

118. Yu, S.; Wang, G.; Shi, Y.; Xu, H.; Zheng, Y.; Chen, Y. MCMs in cancer: Prognostic potential and mechanisms. Anal. Cell Pathol. 2020, 2020, 3750294. [CrossRef]

119. Gou, K.; Liu, J.; Feng, X.; Li, H.; Yuan, Y.; Xing, C. Expression of minichromosome maintenance proteins (MCM) and cancer prognosis: A meta-analysis. J. Cancer 2018, 9, 1518-1526. [CrossRef]

120. Lin, C.; Wu, H.; Hsu, Y.; Cheng, T.; Liu, J.; Huang, R.; Hsiao, T.; Wang, C.; Hung, P.; Lan, A.; et al. Suppression of drug-resistant non-small-cell lung cancer with inhibitors targeting minichromosomal maintenance protein. J. Med. Chem. 2020, 63, 3172-3187. [CrossRef] [PubMed]

121. Lord, C.J.; Ashworth, A. PARP inhibitors: Synthetic lethality in the clinic. Science 2017, 355, 1152-1158. [CrossRef]

122. Jain, P.G.; Patel, B.D. Medicinal chemistry approaches of poly ADP-ribose polymerase 1 (PARP1) inhibitors as anticancer agents -A recent update. Eur. J. Med. Chem. 2019, 165, 198-215. [CrossRef] [PubMed]

123. Min, R.; Wu, W.; Wang, M.; Tang, L.; Chen, D.; Zhao, H.; Zhang, C.; Jiang, Y. Discovery of 2-(1-(3-(4-chloroxyphenyl)-3-oxopropyl)pyrrolidine-3-yl)-1H-benzo[d]imidazole-4-carboxamide: A potent poly(ADP-ribose) polymerase (PARP) inhibitor for treatment of cancer. Molecules 2019, 24, 1901. [CrossRef]

124. Barneda-Zahonero, B.; Parra, M. Histone deacetylases and cancer. Mol. Oncol. 2012, 6, 579-589. [CrossRef] 
125. Ai, T.; Cui, H.; Chen, L. Multi-targeted histone deacetylase inhibitors in cancer therapy. Curr. Med. Chem. 2012, $19,475-487$. [CrossRef] [PubMed]

126. West, A.C.; Johnstone, R.W. New and emerging HDAC inhibitors for cancer treatment. J. Clin. Investig. 2014, 124, 30-39. [CrossRef] [PubMed]

127. McClure, J.J.; Li, X.; Chou, C.J. Advances and challenges of HDAC inhibitors in cancer therapeutics. Adv. Cancer Res. 2018, 138, 183-211. [PubMed]

128. Chen, D.; Soh, C.K.; Goh, W.H.; Wang, Z.; Wang, H. Synthesis and biological evaluation of 6-phenylpurine linked hydroxamates as novel histone deacetylase inhibitors. Bioorg. Chem. 2020, 98, 103724. [CrossRef]

129. Li, T.; Zhang, C.; Hassan, S.; Liu, X.; Song, F.; Chen, K.; Zhang, W.; Yang, J. Histone deacetylase 6 in cancer. J. Hematol. Oncol. 2018, 11, 111. [CrossRef] [PubMed]

130. Mackwitz, M.K.W.; Hamacher, A.; Osko, J.D.; Held, J.; Schöler, A.; Christianson, D.W.; Kassack, M.U.; Hansen, F.K. Multicomponent synthesis and binding mode of imidazo[1,2-a]pyridine-capped selective HDAC6 inhibitors. Org. Lett. 2018, 20, 3255-3258. [CrossRef] [PubMed]

131. Nepali, K.; Chang, T.Y.; Lai, M.J.; Hsu, K.C.; Yen, Y.; Lin, T.E.; Lee, S.B.; Liou, J.P. Purine/purine isoster based scaffolds as new derivatives of benzamide class of HDAC inhibitors. Eur. J. Med. Chem. 2020, 196, 112291. [CrossRef] [PubMed]

132. Chen, X.; Gong, G.; Chen, X.; Song, R.; Duan, M.; Qiao, R.; Jiao, Y.; Qi, J.; Chen, Y.; Zhu, Y. Design, synthesis and biological evaluation of novel benzoylimidazole derivatives as Raf and histone deacetylases dual inhibitors. Chem. Pharm. Bull. 2019, 67, 1116-1122. [CrossRef]

133. Yun, F.; Cheng, C.; Ullah, S.; Yuan, Q. Design, synthesis and biological evaluation of novel histone deacetylase1/2 (HDAC1/2) and cyclin-dependent kinase2 (CDK2) dual inhibitors against malignant cancer. Eur. J. Med. Chem. 2020, 198, 112322. [CrossRef] [PubMed]

134. Majello, B.; Gorini, F.; Saccà, C.D.; Amente, S. Expanding the role of the histone lysine-specific demethylase LSD1 in cancer. Cancers 2019, 11, 324. [CrossRef] [PubMed]

135. Romussi, A.; Cappa, A.; Vianello, P.; Brambillasca, S.; Cera, M.R.; Dal Zuffo, R.; Fagà, G.; Fattori, R.; Moretti, L.; Trifirò, P.; et al. Discovery of reversible inhibitors of KDM1A efficacious in acute myeloid leukemia models. ACS Med. Chem. Lett. 2020, 11, 754-759. [CrossRef]

136. Wang, S.; Zhao, Y.; Aguilar, A.; Bernard, D.; Yang, C.Y. Targeting the MDM2-p53 protein-protein interaction for new cancer therapy: Progress and challenges. Cold Spring Harb. Perspect. Med. 2017, 7, a026245. [CrossRef]

137. Konopleva, M.; Martinelli, G.; Daver, N.; Papayannidis, C.; Wei, A.; Higgins, B.; Ott, M.; Mascarenhas, J.; Andreeff, M. MDM2 inhibition: An important step forward in cancer therapy. Leukemia 2020, 34, 2858-2874. [CrossRef] [PubMed]

138. He, S.; Dong, G.; Wu, S.; Fang, K.; Miao, Z.; Wang, W.; Sheng, C. Small molecules simultaneously inhibiting p53-murine double minute 2 (MDM2) interaction and histone deacetylases (HDACs): Discovery of novel multitargeting antitumor agents. J. Med. Chem. 2018, 61, 7245-7260. [CrossRef]

139. Cochran, A.G.; Conery, A.R.; Sims, R.J., III. Bromodomains: A new target class for drug development. Nat. Rev. Drug Discov. 2019, 18, 609-628. [CrossRef]

140. Yang, Y.; Chen, P.; Zhao, L.; Zhang, F.; Zhang, B.; Xu, C.; Zhang, H.; Zhou, J. Exploiting the 7-methylimidazo[1,5- $a]$ pyrazin-8(7H)one scaffold for the development of novel chemical inhibitors for Bromodomain and Extraterminal Domain (BET) family. Bioorg. Chem. 2019, 90, 103044. [CrossRef]

141. Schapira, M.; Tyers, M.; Torrent, M.; Arrowsmith, C. WD40 repeat domain proteins: A novel target class? Nat. Rev. Drug Discov. 2017, 16, 773-786. [CrossRef]

142. Lu, K.; Tao, H.; Si, X.; Chen, Q. The histone H3 lysine 4 presenter WDR5 as an oncogenic protein and novel epigenetic target in cancer. Front. Oncol. 2018, 8, 502. [CrossRef]

143. Thomas, L.R.; Wang, Q.; Grieb, B.C.; Phan, J.; Foshage, A.M.; Sun, Q.; Olejniczak, E.T.; Clark, T.; Dey, S.; Lorey, S.; et al. Interaction with WDR5 promotes target gene recognition and tumorigenesis by MYC. Mol. Cell 2015, 58, 440-452. [CrossRef] [PubMed]

144. Tian, J.; Teuscher, K.; Aho, E.; Alvarado, J.; Mills, J.; Meyers, K.; Gogliotti, R.; Han, C.; Macdonald, J.; Sai, J.; et al. Discovery and structure-based optimization of potent and selective WD repeat domain 5 (WDR5) inhibitors containing a dihydroisoquinolinone bicyclic core. J. Med. Chem. 2020, 63, 656-675. [CrossRef]

145. Chacón Simon, S.; Wang, F.; Thomas, L.; Phan, J.; Zhao, B.; Olejniczak, E.; Macdonald, J.; Shaw, J.; Schlund, C.; Payne, W.; et al. Discovery of WD repeat-containing protein 5 (WDR5)-MYC inhibitors using fragment-based methods and structure-based design. J. Med. Chem. 2020, 63, 4315-4333. [CrossRef]

146. Yang, L.; Lin, S.; Xu, L.; Lin, J.; Zhao, C.; Huang, X. Novel activators and small-molecule inhibitors of STAT3 in cancer. Cytokine Growth Factor Rev. 2019, 49, 10-22. [CrossRef]

147. Su, J.C.; Chang, C.H.; Wu, S.H.; Shiau, C.W. Novel imidazopyridine suppresses STAT3 activation by targeting SHP-1. J. Enzyme Inhib. Med. Chem. 2018, 33, 1248-1255. [CrossRef] [PubMed]

148. Wang, X.; He, Q.; Wu, K.; Guo, T.; Du, X.; Zhang, H.; Fang, L.; Zheng, N.; Zhang, Q.; Ye, F. Design, synthesis and activity of novel 2,6-disubstituted purine derivatives, potential small molecule inhibitors of signal transducer and activator of transcription 3 . Eur. J. Med. Chem. 2019, 179, 218-232. [CrossRef] [PubMed]

149. Hornyák, L.; Dobos, N.; Koncz, G.; Karányi, Z.; Páll, D.; Szabó, Z.; Halmos, G.; Székvölgyi, L. The role of indoleamine-2,3dioxygenase in cancer development, diagnostics, and therapy. Front. Immunol. 2018, 9, 151. [CrossRef] 
150. Tu, W.; Yang, F.; Xu, G.; Chi, J.; Liu, Z.; Peng, W.; Hu, B.; Zhang, L.; Wan, H.; Yu, N.; et al. Discovery of imidazoisoindole derivatives as highly potent and orally active indoleamine-2,3-dioxygenase inhibitors. ACS Med. Chem. Lett. 2019, 10, 949-953. [CrossRef]

151. Tojo, S.; Kohno, T.; Tanaka, T.; Kamioka, S.; Ota, Y.; Ishii, T.; Kamimoto, K.; Asano, S.; Isobe, Y. Crystal structures and structureactivity relationships of imidazothiazole derivatives as IDO1 inhibitors. ACS Med. Chem. Lett. 2014, 5, 1119-1123. [CrossRef]

152. Griglio, A.; Torre, E.; Serafini, M.; Bianchi, A.; Schmid, R.; Coda Zabetta, G.; Massarotti, A.; Sorba, G.; Pirali, T.; Fallarini, S. A multicomponent approach in the discovery of indoleamine 2,3-dioxygenase 1 inhibitors: Synthesis, biological investigation and docking studies. Bioorg. Med. Chem. Lett. 2018, 28, 651-657. [CrossRef]

153. Serafini, M.; Torre, E.; Aprile, S.; Massarotti, A.; Fallarini, S.; Pirali, T. Synthesis, docking and biological evaluation of a novel class of imidazothiazoles as IDO1 inhibitors. Molecules 2019, 24, 1874. [CrossRef] [PubMed]

154. Serafini, M.; Torre, E.; Aprile, S.; Grosso, E.; Gesù, A.; Griglio, A.; Colombo, G.; Travelli, C.; Paiella, S.; Adamo, A.; et al. Discovery of highly potent benzimidazole derivatives as indoleamine 2,3-dioxygenase-1 (IDO1) inhibitors: From structure-based virtual screening to in vivo pharmacodynamic activity. J. Med. Chem. 2020, 63, 3047-3065. [CrossRef] [PubMed]

155. Ahmad, I. Shagufta Recent developments in steroidal and nonsteroidal aromatase inhibitors for the chemoprevention of estrogendependent breast cancer. Eur. J. Med. Chem. 2015, 102, 375-386. [CrossRef] [PubMed]

156. Kalalinia, F.; Jouya, M.; Komachali, A.K.; Aboutourabzadeh, S.M.; Karimi, G.; Behravan, J.; Abnous, K.; Etemad, L.; Kamali, H.; Hadizadeh, F. Design, synthesis, and biological evaluation of new azole derivatives as potent aromatase inhibitors with potential effects against breast cancer. Anticancer Agents Med. Chem. 2018, 18, 1016-1024. [CrossRef] [PubMed]

157. Zhang, W.; Liu, Y.; Hu, H.; Huang, H.; Bao, Z.; Yang, P.; Wang, Y.; You, G.; Yan, W.; Jiang, T.; et al. ALDH1A3: A marker of mesenchymal phenotype in gliomas associated with cell invasion. PLoS ONE 2015, 10, e0142856. [CrossRef]

158. Quattrini, L.; Gelardi, E.; Coviello, V.; Sartini, S.; Ferraris, D.M.; Mori, M.; Nakano, I.; Garavaglia, S.; La Motta, C. Imidazo[1,2a]pyridine derivatives as aldehyde dehydrogenase inhibitors: Novel chemotypes to target glioblastoma stem cells. J. Med. Chem. 2020, 63, 4603-4616. [CrossRef] [PubMed]

159. Chau, L.Y. Heme oxygenase-1: Emerging target of cancer therapy. J. Biomed. Sci. 2015, 22, 22. [CrossRef]

160. Ciaffaglione, V.; Intagliata, S.; Pittalà, V.; Marrazzo, A.; Sorrenti, V.; Vanella, L.; Rescifina, A.; Floresta, G.; Sultan, A.; Greish, K.; et al. New arylethanolimidazole derivatives as HO-1 inhibitors with cytotoxicity against MCF-7 breast cancer cells. Int. J. Mol. Sci. 2020, 21, 1923. [CrossRef]

161. Astorgues-Xerri, L.; Riveiro, M.; Tijeras-Raballand, A.; Serova, M.; Neuzillet, C.; Albert, S.; Raymond, E.; Faivre, S. Unraveling galectin-1 as a novel therapeutic target for cancer. Cancer Treat. Rev. 2014, 40, 307-319. [CrossRef]

162. Goud, N.S.; Ghouse, S.M.; Vishnu, J.; Komal, D.; Talla, V.; Alvala, R.; Pranay, J.; Kumar, J.; Qureshi, I.A.; Alvala, M. Synthesis of 1-benzyl-1H-benzimidazoles as galectin-1 mediated anticancer agents. Bioorg. Chem. 2019, 89, 103016. [CrossRef] [PubMed]

163. Sridhar Goud, N.; Pooladanda, V.; Muni Chandra, K.; Lakshmi Soukya, P.S.; Alvala, R.; Kumar, P.; Nagaraj, C.; Dawn Bharath, R.; Qureshi, I.; Godugu, C.; et al. Novel benzimidazole-triazole hybrids as apoptosis inducing agents in lung cancer: Design, synthesis, ${ }^{18}$ F-radiolabeling \& galectin-1 inhibition studies. Bioorg. Chem. 2020, 102, 104125.

164. Chatterjee, A.; Gupta, S. The multifaceted role of glutathione S-transferases in cancer. Cancer Lett. 2018, 433, 33-42. [CrossRef] [PubMed]

165. Abd El-Karim, S.S.; Anwar, M.M.; Zaki, E.R.; Elseginy, S.A.; Nofal, Z.M. Synthesis and molecular modeling of new benzimidazoles as glutathione S-transferase inhibitors and anticancer agents. Future Med. Chem. 2018, 10, 157-181. [CrossRef] [PubMed]

166. Orafaie, A.; Matin, M.M.; Sadeghian, H. The importance of 15-lipoxygenase inhibitors in cancer treatment. Cancer Metastasis Rev. 2018, 37, 397-408. [CrossRef] [PubMed]

167. Afifi, O.S.; Shaaban, O.G.; Abd El Razik, H.A.; Shams El-Dine, S.E.A.; Ashour, F.A.; El-Tombary, A.A.; Abu-Serie, M.M. Synthesis and biological evaluation of purine-pyrazole hybrids incorporating thiazole, thiazolidinone or rhodanine moiety as 15 -LOX inhibitors endowed with anticancer and antioxidant potential. Bioorg. Chem. 2019, 87, 821-837. [CrossRef] [PubMed]

168. Sharma, D.; Kumar, S.; Narasimhan, B. Estrogen alpha receptor antagonists for the treatment of breast cancer: A review. Chem. Cent. J. 2018, 12, 107. [CrossRef]

169. Singla, R.; Gupta, K.B.; Upadhyay, S.; Dhiman, M.; Jaitak, V. Design, synthesis and biological evaluation of novel indolebenzimidazole hybrids targeting estrogen receptor alpha (ER- $\alpha$ ). Eur. J. Med. Chem. 2018, 146, 206-219. [CrossRef] [PubMed]

170. Robey, R.W.; Pluchino, K.M.; Hall, M.D.; Fojo, A.T.; Bates, S.E.; Gottesman, M.M. Revisiting the role of ABC transporters in multidrug-resistant cancer. Nat. Rev. Cancer 2018, 18, 452-464. [CrossRef]

171. Wang, S.; Wang, S.Q.; Teng, Q.X.; Yang, L.; Lei, Z.N.; Yuan, X.; Huo, J.F.; Chen, X.; Wang, M.; Yu, B.; et al. Structure-based design, synthesis, and biological evaluation of new triazolo[1,5- $a$ ]pyrimidine derivatives as highly potent and orally active ABCB1 modulators. J. Med. Chem. 2020, 63, 15979-15996. [CrossRef] [PubMed]

172. Shrestha, L.; Bolaender, A.; Patel, H.J.; Taldone, T. Heat shock protein (HSP) drug discovery and development: Targeting heat shock proteins in disease. Curr. Top. Med. Chem. 2016, 16, 2753-2764. [CrossRef] [PubMed]

173. Sanchez, J.; Carter, T.R.; Cohen, M.S.; Blagg, B.S.J. Old and new approaches to target the Hsp90 chaperone. Curr. Cancer Drug Targets 2020, 20, 253-270. [CrossRef]

174. Uno, T.; Kawai, Y.; Yamashita, S.; Oshiumi, H.; Yoshimura, C.; Mizutani, T.; Suzuki, T.; Chong, K.T.; Shigeno, K.; Ohkubo, M.; et al. Discovery of 3-ethyl-4-(3-isopropyl-4-(4-(1-methyl-1H-pyrazol-4-yl)-1H-imidazol-1-yl)-1H-pyrazolo[3,4-b]pyridin-1-yl)benzamide (TAS-116) as a potent, selective, and orally available HSP90 inhibitor. J. Med. Chem. 2019, 62, 531-551. [CrossRef] [PubMed] 
175. Karataş, M.O.; Tekin, S.; Alici, B.; Sandal, S. Cytotoxic effects of coumarin substituted benzimidazolium salts against human prostate and ovarian cancer cells. J. Chem. Sci. 2019, 131, 69. [CrossRef]

176. Wang, X.Q.; Chen, X.B.; Ye, P.T.; Yang, Z.X.; Bai, M.J.; Duan, S.Y.; Li, Y.; Yang, X.D. Synthesis and biological evaluation of novel 3-benzylcoumarin-imidazolium salts. Bioorg. Med. Chem. Lett. 2020, 30, 126896. [CrossRef]

177. Akkoç, S. Derivatives of 1-(2-(piperidin-1-yl)ethyl)-1H-benzo[d]imidazole: Synthesis, characterization, determining of electronic properties and cytotoxicity studies. ChemistrySelect 2019, 4, 4938-4943. [CrossRef]

178. Yang, J.L.; Ma, Y.H.; Li, Y.H.; Zhang, Y.P.; Tian, H.C.; Huang, Y.C.; Li, Y.; Chen, W.; Yang, L.J. Design, synthesis, and anticancer activity of novel trimethoxyphenyl-derived chalcone-benzimidazolium salts. ACS Omega 2019, 4, 20381-20393. [CrossRef]

179. Kuang, W.B.; Huang, R.Z.; Qin, J.L.; Lu, X.; Qin, Q.P.; Zou, B.Q.; Chen, Z.F.; Liang, H.; Zhang, Y. Design, synthesis and pharmacological evaluation of new 3-(1H-benzimidazol-2-yl)quinolin-2(1H)-one derivatives as potential antitumor agents. Eur. J. Med. Chem. 2018, 157, 139-150. [CrossRef] [PubMed]

180. Mohareb, R.M.; Abdallah, A.E.M.; Mohamed, A.A. Synthesis of novel thiophene, thiazole and coumarin derivatives based on benzimidazole nucleus and their cytotoxicity and toxicity evaluations. Chem. Pharm. Bull. 2018, 66, 309-318. [CrossRef] [PubMed]

181. Chouiter, M.I.; Boulebd, H.; Pereira, D.M.; Valentão, P.; Andrade, P.B.; Belfaitah, A.; Silva, A.M. New chalcone-type compounds and 2-pyrazoline derivatives: Synthesis and caspase-dependent anticancer activity. Future Med. Chem. 2020, 12, 493-509. [CrossRef] [PubMed]

182. Hsieh, C.Y.; Ko, P.W.; Chang, Y.J.; Kapoor, M.; Liang, Y.C.; Chu, H.L.; Lin, H.H.; Horng, J.C.; Hsu, M.H. Design and synthesis of benzimidazole-chalcone derivatives as potential anticancer agents. Molecules 2019, 24, 3259. [CrossRef]

183. Suk, F.M.; Liu, C.L.; Hsu, M.H.; Chuang, Y.T.; Wang, J.P.; Liao, Y.J. Treatment with a new benzimidazole derivative bearing a pyrrolidine side chain overcomes sorafenib resistance in hepatocellular carcinoma. Sci. Rep. 2019, 9, 17259. [CrossRef]

184. Rasal, N.; Sonawane, R.; Jagtap, S. Potential 2,4-dimethyl-1H-pyrrole-3-carboxamide bearing benzimidazole template: Design, synthesis, in vitro anticancer and in silico ADME study. Bioorg. Chem. 2020, 97, 103660. [CrossRef] [PubMed]

185. Li, A.; Yang, Y.; Wang, W.; Liu, Q.; Sun, Y.; Gu, W. Synthesis, cytotoxicity and apoptosis-inducing activity of novel $1 H$ benzo[d]imidazole derivatives of dehydroabietic acid. J. Chin. Chem. Soc. 2020, 67, 1668-1678. [CrossRef]

186. Bistrović, A.; Krstulović, L.; Harej, A.; Grbčić, P.; Sedić, M.; Koštrun, S.; Pavelić, S.K.; Bajić, M.; Raić-Malić, S. Design, synthesis and biological evaluation of novel benzimidazole amidines as potent multi-target inhibitors for the treatment of non-small cell lung cancer. Eur. J. Med. Chem. 2018, 143, 1616-1634. [CrossRef] [PubMed]

187. Ashok, D.; Ram Reddy, M.; Nagaraju, N.; Dharavath, R.; Ramakrishna, K.; Gundu, S.; Shravani, P.; Sarasija, M. Microwave-assisted synthesis and in vitro antiproliferative activity of some novel 1,2,3-triazole-based pyrazole aldehydes and their benzimidazole derivatives. Med. Chem. Res. 2020, 29, 699-706. [CrossRef]

188. Meenakshisundaram, S.; Manickam, M.; Pillaiyar, T. Exploration of imidazole and imidazopyridine dimers as anticancer agents: Design, synthesis, and structure-activity relationship study. Arch. Pharm. (Weinheim) 2019, 352, e1900011. [CrossRef]

189. Güçlü, D.; Kuzu, B.; Tozlu, İ.; Taşpınar, F.; Canpınar, H.; Taşpınar, M.; Menges, N. Synthesis of novel imidazopyridines and their biological evaluation as potent anticancer agents: A promising candidate for glioblastoma. Bioorg. Med. Chem. Lett. 2018, 28, 2647-2651. [CrossRef]

190. Khalili, F.; Akrami, S.; Safavi, M.; Mohammadi-Khanaposhtani, M.; Saeedi, M.; Ardestani, S.K.; Larijani, B.; Zonouzi, A.; Tehrani, M.B.; Mahdavi, M. Design, synthesis, in vitro cytotoxic activity evaluation, and study of apoptosis inducing effect of new styrylimidazo[1,2-a]pyridines as potent anti-breast cancer agents. Anticancer Agents Med. Chem. 2019, 19, 265-275. [CrossRef] [PubMed]

191. Chitti, S.; Singireddi, S.; Santosh Kumar Reddy, P.; Trivedi, P.; Bobde, Y.; Kumar, C.; Rangan, K.; Ghosh, B.; Sekhar, K. Design, synthesis and biological evaluation of 2-(3,4-dimethoxyphenyl)-6 (1,2,3,6-tetrahydropyridin-4-yl)imidazo[1,2-a]pyridine analogues as antiproliferative agents. Bioorg. Med. Chem. Lett. 2019, 29, 2551-2558. [CrossRef] [PubMed]

192. Mani, G.; Anchi, P.; Sunkari, S.; Donthiboina, K.; Godugu, C.; Shankaraiah, N.; Kamal, A. Synthesis of (Z)-3-(arylamino)-1-(3phenylimidazo[1,5-a]pyridin-1-yl)prop-2-en-1-ones as potential cytotoxic agents. Bioorg. Med. Chem. Lett. 2020, $30,127432$. [CrossRef] [PubMed]

193. Mantipally, M.; Gangireddy, M.R.; Gundla, R.; Badavath, V.N.; Mandha, S.R.; Maddipati, V.C. Rational design, molecular docking and synthesis of novel homopiperazine linked imidazo[1,2-a]pyrimidine derivatives as potent cytotoxic and antimicrobial agents. Bioorg. Med. Chem. Lett. 2019, 29, 2248-2253. [CrossRef] [PubMed]

194. El-Borai, M.A.; Awad, M.K.; Rizk, H.F.; Atlam, F.M. Design, synthesis and docking study of novel imidazolyl pyrazolopyridine derivatives as antitumor agents targeting MCF7 cell line. Curr. Org. Synth. 2018, 15, 275-285. [CrossRef]

195. Liu, Z.; Zhang, Z.; Zhang, W.; Yan, D. 2-Substituted-1-(2-morpholinoethyl)-1H-naphtho[2,3- $d$ ]imidazole-4,9-diones: Design, synthesis and antiproliferative activity. Bioorg. Med. Chem. Lett. 2018, 28, 2454-2458. [CrossRef]

196. Wei, Q.; Li, J.; Tang, F.; Yin, Y.; Zhao, Y.; Yao, Q. Synthesis and biological evaluation of novel 2-arylvinyl-substituted naphtho[2,3d]imidazolium halide derivatives as potent antitumor agents. Eur. J. Med. Chem. 2018, 144, 504-516. [CrossRef] [PubMed]

197. Hebishy, A.M.S.; Abdelfattah, M.S.; Elmorsy, A.; Elwahy, A.H.M. ZnO nanoparticles catalyzed synthesis of bis- and poly(imidazoles) as potential anticancer agents. Synth. Commun. 2020, 50, 980-996. [CrossRef]

198. Ghanbarimasir, Z.; Bekhradnia, A.; Morteza-Semnani, K.; Rafiei, A.; Razzaghi-Asl, N.; Kardan, M. Design, synthesis, biological assessment and molecular docking studies of new 2-aminoimidazole-quinoxaline hybrids as potential anticancer agents. Spectrochim. Acta A Mol. Biomol. Spectrosc. 2018, 194, 21-35. [CrossRef] [PubMed] 
199. Yavuz, S.Ç.; Akkoç, S.; Sarıpınar, E. The cytotoxic activities of imidazole derivatives prepared from various guanylhydrazone and phenylglyoxal monohydrate. Synth. Commun. 2019, 49, 3198-3209. [CrossRef]

200. Demjén, A.; Alföldi, R.; Angyal, A.; Gyuris, M.; Hackler, L., Jr.; Szebeni, G.J.; Wölfling, J.; Puskás, L.G.; Kanizsai, I. Synthesis, cytotoxic characterization, and SAR study of imidazo[1,2-b]pyrazole-7-carboxamides. Arch. Pharm. 2018, 351, e1800062. [CrossRef] [PubMed]

201. Shaik, S.P.; Reddy, T.S.; Sunkari, S.; Rao, A.V.S.; Babu, K.S.; Bhargava, S.K.; Kamal, A. Synthesis of benzo[d]imidazo[2,1- $b]$ thiazolepropenone conjugates as cytotoxic and apoptotic inducing agents. Anticancer Agents Med. Chem. 2019, 19, 347-355. [CrossRef]

202. Hu, Y.; Li, N.; Zhang, J.; Wang, Y.; Chen, L.; Sun, J. Artemisinin-indole and artemisinin-imidazole hybrids: Synthesis, cytotoxic evaluation and reversal effects on multidrug resistance in MCF-7/ADR cells. Bioorg. Med. Chem. Lett. 2019, 29, 1138-1142. [CrossRef] [PubMed]

203. Yoon, J.S.; Jarhad, D.B.; Kim, G.; Nayak, A.; Zhao, L.X.; Yu, J.; Kim, H.R.; Lee, J.Y.; Mulamoottil, V.A.; Chandra, G.; et al. Design, synthesis and anticancer activity of fluorocyclopentenyl-purines and -pyrimidines. Eur. J. Med. Chem. 2018, 155, 406-417. [CrossRef] [PubMed]

204. Pan, X.; Tao, L.; Ji, M.; Chen, X.; Liu, Z. Synthesis and cytotoxicity of novel imidazo[4,5- $d$ ]azepine compounds derived from marine natural product ceratamine A. Bioorg. Med. Chem. Lett. 2018, 28, 866-868. [CrossRef]

205. Tuncbilek, M.; Kucukdumlu, A.; Guven, E.B.; Altiparmak, D.; Cetin-Atalay, R. Synthesis of novel 6-substituted amino-9-( $\beta$-Dribofuranosyl)purine analogs and their bioactivities on human epithelial cancer cells. Bioorg. Med. Chem. Lett. 2018, 28, 235-239. [CrossRef]

206. Borowiecki, P.; Wińska, P.; Bretner, M.; Gizińska, M.; Koronkiewicz, M.; Staniszewska, M. Synthesis of novel proxyphylline derivatives with dual anti-Candida albicans and anticancer activity. Eur. J. Med. Chem. 2018, 150, 307-333. [CrossRef]

207. Kowalska, A.; Pluta, K.; Latocha, M. Synthesis and anticancer activity of multisubstituted purines and xanthines with one or two propynylthio and aminobutynylthio groups. Med. Chem. Res. 2018, 27, 1384-1395. [CrossRef]

208. Zhao, T.Q.; Zhao, Y.D.; Liu, X.Y.; Wang, B.; Li, Z.H.; He, Z.X.; Zhang, X.H.; Liang, J.J.; Ma, L.Y.; Liu, H.M. Discovery of 6-chloro-2(propylthio)-8,9-dihydro-7H-purines containing a carboxamide moiety as potential selective anti-lung cancer agents. Eur. J. Med. Chem. 2018, 151, 327-338. [CrossRef] [PubMed]

209. Shaaban, O.G.; Abd El Razik, H.A.; SE, A.S.E.-D.; Ashour, F.A.; El-Tombary, A.A.; Afifi, O.S.; Abu-Serie, M.M. Purines and triazolo[4,3-e]purines containing pyrazole moiety as potential anticancer and antioxidant agents. Future Med. Chem. 2018, 10, 1449-1464. [CrossRef]

210. Salas, C.; Zarate, A.M.; Kryštof, V.; Mella, J.; Faundez, M.; Brea, J.; Loza, M.I.; Brito, I.; Hendrychová, D.; Jorda, R.; et al. Promising 2,6,9-trisubstituted purine derivatives for anticancer compounds: Synthesis, 3D-QSAR, and preliminary biological assays. Int. J. Mol. Sci. 2020, 21, 161. [CrossRef]

211. Liu, W.; Wang, Z.; Xu, F.; Li, Q.; Wang, H.; Bian, Q.; Hu, F. Synthesis and activity investigation of novel $1 H$-purin-6(9H)-one and $3 H$-imidazo[4,5-d][1,2,3]triazin-4(7H)-one derivatives. ACS Omega 2019, 4, 15742-15753. [CrossRef]

212. Fernández-Sáez, N.; Rubio-Ruiz, B.; Campos, J.M.; Unciti-Broceta, A.; Carrión, M.D.; Camacho, M.E. Purine derivatives with heterocyclic moieties and related analogs as new antitumor agents. Future Med. Chem. 2019, 11, 83-95. [CrossRef] [PubMed]

213. Sutanto, F.; Konstantinidou, M.; Dömling, A. Covalent inhibitors: A rational approach to drug discovery. RSC Med. Chem. 2020, 11, 876-884. [CrossRef] [PubMed]

214. Antolin, A.A.; Workman, P.; Mestres, J.; Al-Lazikani, B. Polypharmacology in precision oncology: Current applications and future prospects. Curr. Pharm. Des. 2016, 22, 6935-6945. [CrossRef] [PubMed]

215. Thomas, L.R.; Adams, C.M.; Fesik, S.W.; Eischen, C.M.; Tansey, W.P. Targeting MYC through WDR5. Mol. Cell. Oncol. 2020, 7, 1709388. [CrossRef]

216. Doi, T.; Kurokawa, Y.; Sawaki, A.; Komatsu, Y.; Ozaka, M.; Takahashi, T.; Naito, Y.; Ohkubo, S.; Nishida, T. Efficacy and safety of TAS-116, an oral inhibitor of heat shock protein 90, in patients with metastatic or unresectable gastrointestinal stromal tumour refractory to imatinib, sunitinib and regorafenib: A phase II, single-arm trial. Eur. J. Cancer 2019, 121, 29-39. [CrossRef] 